\title{
ARTICLES
}

\section{Stickiness and Incomplete Contracts}

\author{
Julian Nyarko†
}

Both economic theory and legal theory assume that sophisticated parties routinely aim to write contracts that are optimal, in the sense of maximizing the parties' joint surplus. But more recent studies analyzing corporate and government bond agreements have suggested that some contract provisions are highly path dependent, or "sticky," with future agreements only rarely improving upon previous ones.

Analyzing half a million contracts using automated text analysis, this Article demonstrates that the stickiness hypothesis explains the striking lack of dispute resolution clauses that can be found in agreements between even the most sophisticated commercial parties. When drafting these contracts, external counsel rely heavily on templates, and whether a contract includes a dispute settlement provision is almost exclusively driven by the template that is used to supply the first draft. There is no evidence to suggest that counsel negotiate over the inclusion of dispute resolution clauses, nor that law firm templates are revised in response to changes in the costs and benefits of incomplete contracting.

Together, the findings reveal a distinct apathy toward addressing dispute resolution through contracting. From an institutional perspective, this suggests that the role of default rules in contract law is more important than is often assumed. Whereas traditional accounts hold that commercial actors would simply contract around inefficient defaults, the evidence produced in this Article highlights that

$\dagger$ Assistant Professor of Law, Stanford Law School. For helpful comments and suggestions, I thank Adam Badawi, Douglas Baird, Robert Bartlett, Andrew Bradt, Guy-Uriel Charles, Benjamin Chen, Adam Chilton, Albert Choi, Ryan Copus, Robert Cooter, John Coyle, Kevin Davis, John DeFigueredo, Josh Fischman, Jeffrey Gordon, Joe Grundfest, Mitu Gulati, Andrew Guzman, Deborah Hensler, Tim Holbrook, Bert Huang, William Hubbard, Matthew Jennejohn, Francine Lafontaine, Katerina Linos, Jonathan Masur, Justin McCrary, Joshua Mitts, Kevin Quinn, Bertrall Ross, Sarath Sanga, Robert Scott, Megan Stevenson, Eric Talley, Glenn West, Diego Zambrano, and Eyak Zamir, as well as the participants of workshops at Columbia Law School, NYU School of Law, Stanford Law School, the University of Chicago Law School, University of Virginia School of Law, University of Michigan Law School, UC Davis School of Law, University of Hamburg Faculty of Law, the 2020 American Bar Association M\&A Committee Meeting, the 2020 Association of American Law Schools Annual Meeting, the 2020 Stanford-IACCM Symposium, the 2019 Northwestern Conference on Law and Textual Analysis, the 2019 Annual Empirical Contracts Workshop at Penn, the 2019 Annual Meeting of the German Law and Economics Association, the 2018 Conference on Empirical Legal Studies, the 2018 Conference on Empirical Legal Studies in Europe, and the 2018 International Conference on the Economics of Litigation. 
defaults are significantly important for transactions between even the most sophisticated commercial actors.

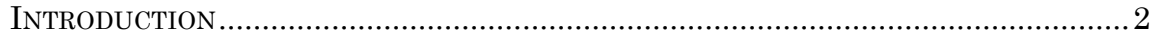

I. A Brief Primer on Forum Choice............................................................... 10

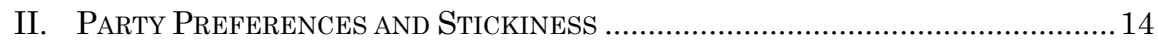

A. Dispute Resolution Clauses: The Benefits .............................................16

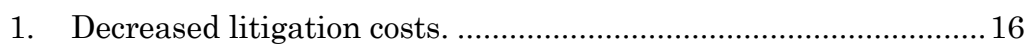

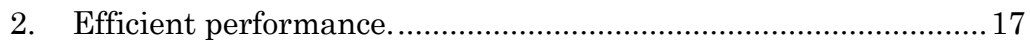

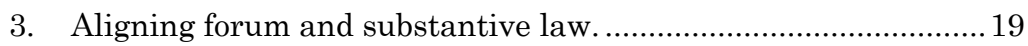

B. Dispute Resolution Clauses: The Costs.................................................20

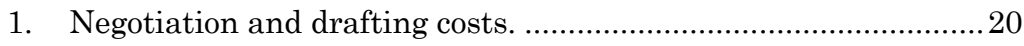

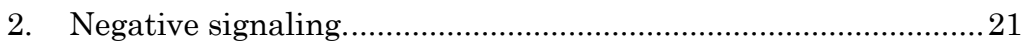

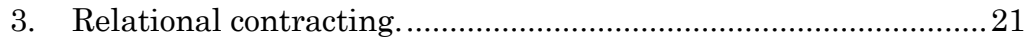

4. Uncertainty as a screening device................................................22

C. Law Firms and Contractual Stickiness.................................................23

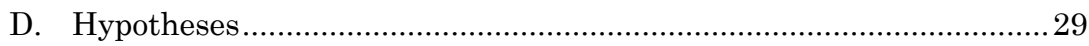

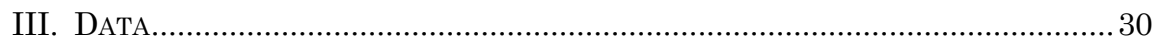

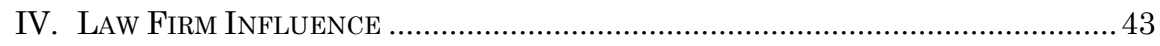

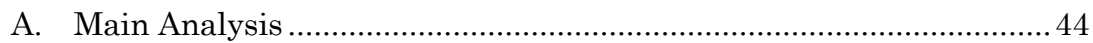

B. Identification Through Law Firm Closure ........................................... 47

V. Stickiness AND FIRST-Mover Advantage ……….........................................5 50

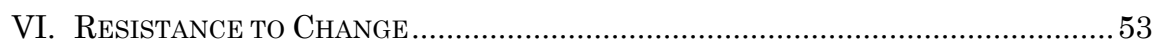

A. Limits on Personal Jurisdiction...............................................................54

B. Affirming Enforceability of Forum Selection Clauses ..........................56

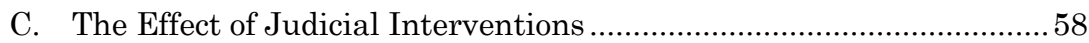

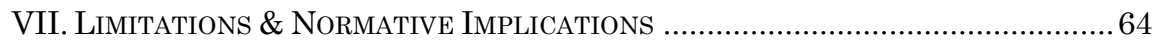

CONCLUSION

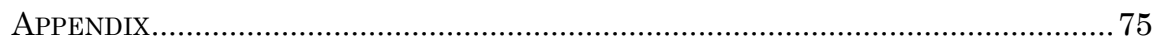

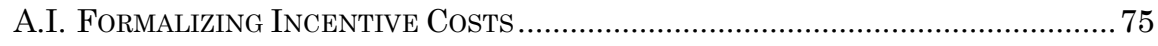

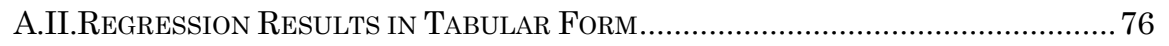

\section{INTRODUCTION}

In the 1990s, Sprint PCS, one of the leading telecommunications companies in the United States, created a wireless affiliate program. Under the affiliate program, Sprint and its partners would conclude several agreements ${ }^{1}$ that established cooperation between the parties. Under the terms of these agreements, the affiliates would invest "hundreds of millions of dollars" in order

1 These agreements typically included a management agreement, a trademark and service mark license agreement, and a services agreement. 
to offer services on behalf of Sprint under the Sprint name. ${ }^{2}$ In return, a noncompete clause stipulated that the affiliates would be the exclusive providers of Sprint services in their regions covered by the affiliate program. ${ }^{3}$

On December 15, 2004, Sprint announced a planned merger with Nextel Communications, Inc., then the fifth-leading provider in the U.S. mobile phone industry. Nextel operated stores and offered services in many parts of the United States, including regions covered by Sprint's affiliate program. After the merger, Nextel's services would be rebranded under the Sprint name. The affiliates did not look favorably upon the planned merger. They alleged that the rebranding of the Nextel stores and services would cause the newly formed Sprint Nextel to directly compete against them in their service areas, thus violating the noncompete provision. Consequently, they filed for an injunction seeking to prevent the merger, alleging a breach of contract.

Conspicuously, however, while the agreements that Sprint concluded with its partners under the affiliate program included a choice-of-law clause determining the substantive law applicable in the dispute, none of them included a choice-of-forum provision that would determine where the partners could sue. ${ }^{4}$ To Sprint, this omission would become detrimental.

In 2005, the affiliates commenced parallel suits in both Delaware $^{5}$ and Illinois. ${ }^{6}$ In 2008, in the context of a separate dispute regarding the acquisition of Clearwire Corporation by Sprint, they pursued a similar strategy. ${ }^{7}$

In an effort to minimize the harm resulting from this multiforum litigation, Sprint negotiated a forbearance agreement, in

2 E.g., Complaint at 1, UbiquiTel Inc. v. Sprint Corp., No. Civ.A. 1489-N (Del. Ch. Dec. 14, 2005), 2005 WL 5758593, at *1.

3 See Sprint PCS Management Agreement $\S 2.3$ (Nov. 5, 1999), https://perma.cc/NBK4-REAP. The agreements that Sprint used with its other affiliates were virtually identical.

4 The agreements did include an arbitration provision for certain subject matters that did not cover injunctions. See, e.g., id. § 14.2.

5 See generally Horizon Pers. Commc'ns, Inc. v. Sprint Corp., No. Civ.A. 1518-N, 2006 WL 2337592 (Del. Ch. Aug. 4, 2006); UbiquiTel Inc. v. Sprint Corp., No. Civ.A. 1489N, 2006 WL 44424 (Del. Ch. Jan. 4, 2006).

6 See Sprint Nextel Corp. v. iPCS, Inc., No. CIV.A. 3746-VCP, 2008 WL 2737409, at *3 (Del. Ch. July 14, 2008) ("iPCS Wireless filed a substantially similar lawsuit against Sprint on July 15, 2005 in Cook County, Illinois.”).

7 See id. at *5 ("On May 12, 2008, three business days after Sprint filed this action in Delaware, [iPCS Wireless] filed suit in Illinois state court . . seeking mirror image relief."). While documents relating to the proceedings in Illinois are not publicly available, the Delaware decision discusses the parallel suits extensively. 
which the parties promised to limit their claims to the jurisdictions in which their respective lawsuits were currently pending and to coordinate discovery in the parallel suits in order to reduce costs. ${ }^{8}$ In addition, the parties amended their existing agreements to include a choice-of-forum provision. ${ }^{9}$ With its less adversarial affiliates, Sprint negotiated exclusive choice-of-forum provisions that would limit its exposure in the future. ${ }^{10}$ However, notwithstanding these attempts, the subsequent proceedings were so complex and costly that Sprint Nextel ultimately resolved the lawsuits by buying eight out of its ten affiliates. The largest of these transactions was the $\$ 4.3$ billion acquisition of Alamosa Holdings in February 2006.11

The Sprint-Nextel merger provides a particularly striking example of the profound negative consequences that it can have to leave important terms in a contract unspecified. And yet, contractual gaps such as these are no exception in even the highestvalue transactions between the most sophisticated actors. For instance, choice-of-forum provisions are similarly absent in the May 2011 underwriting agreement between Merrill Lynch (represented by Cahill Gordon \& Reindel LLP) and Celanese Corp. for $\$ 140$ million, ${ }^{12}$ and the November 2015 common unit purchase agreement between Sunoco (represented by Latham \& Watkins LLP) and Energy Transfer Equity for $\$ 64.5$ million. ${ }^{13}$ Indeed, a systematic study of half a million "material" contracts reported to the Securities and Exchange Commission (SEC) between 2000 and 2016 reveals that dispute settlement provisions are absent in more than half of all agreements. ${ }^{14}$

To students of contract law, this variation in the adoption of dispute settlement provisions presents an intriguing puzzle. We

\footnotetext{
8 See Sprint/IPCs Forbearance Agreement $\S \S 3.1,5.6$ (July 28, 2005), https://perma.cc/BS69-V97Z.

9 See, e.g., Addendum VIII to Sprint PCS Management Agreement and Sprint PCS Services Agreement $\S 40$ (Mar. 16, 2005), https://perma.cc/D829-SXDU.

10 For one example, see Addendum VII to Sprint PCS Management Agreement and Sprint PCS Services Agreement $§ 23$ (Mar. 12, 2007), https://perma.cc/K696-CPAL.

11 Alamosa Holdings' wholly owned subsidiary, AirGate PCS, Inc., had filed a lawsuit against Sprint Nextel in the Delaware Court of Chancery in August 2005. See Verified Complaint for Preliminary Injunctive Relief, Permanent Injunctive Relief, and Declaratory Relief at 1, AirGate PCS, Inc. v. Sprint Corp., No. 1548 (Del. Ch. Aug. 18, 2005), 2005 WL 5770886 , at * 1 .

12 See generally Underwriting Agreement (May 2, 2011), https://perma.cc/VGE8-CBLG.

13 See generally Common Unit Purchase Agreement (Nov. 15, 2015), https://perma.cc/FPJ3-NLC6.

14 Julian Nyarko, We'll See You in ... Court! The Lack of Arbitration Clauses in International Commercial Contracts, 58 INT'L REV. L. \& ECON. 6, 11 (2019).
} 
currently lack any theory that would predict parties to prefer the uncertainties associated with not having a dispute resolution clause over the predictability that comes with choosing a forum ex ante. And even if we could conceive of such a theory ex post facto, it would need to explain not only the existence of contractual gaps with respect to the forum, but also the great variation between different contracts. It is difficult to find consistency in the use of dispute settlement provisions across any coherent dimension that is often thought to induce homogeneity, such as the type of the underlying transaction or the industry. Indeed, even multiple contracts of the same company vary widely in their use of dispute resolution clauses, such that any given company sometimes includes them and sometimes does not. ${ }^{15}$

But if the explanation is neither the identity of the party nor the characteristics of the deal, what does explain the observed variation in contractual terms? To get an anecdotal taste of the empirical argument advanced in this Article, consider the case of Huron Consulting Group Inc., a leading provider of financial services. On July 31, 2007, Huron announced the acquisition of Callaway Partners, LLC. Callaway specializes in finance and accounting project management. The purchase price was $\$ 60$ million, paid in cash. ${ }^{16}$ Then, on January 4, 2007, Huron announced the acquisition of Wellspring Partners LTD for $\$ 65$ million. ${ }^{17}$ On the same day, Huron also announced it had entered into a definitive merger agreement to acquire Glass \& Associates, Inc., a leading turnaround and restructuring firm, for $\$ 30$ million. ${ }^{18}$ What is striking about these acquisitions is that, while the underlying contracts for all of them include a choice-of-law clause specifying the "internal laws of the State of Illinois" as the governing law, ${ }^{19}$ none of them include a dispute settlement provision.

In searching for consistency among the three transactions that may help explain this absence, a glance at the underlying agreements - as filed with the SEC-is instructive. What can be

\footnotetext{
15 See infra fig.2.

16 Huron Consulting Group Acquires Callaway Partners, LLC, HuRon Consulting GRP. (July 31, 2007), https://perma.cc/65WN-ZV63.

17 Huron Consulting Group Acquires Wellspring Partners LTD, HURON CONSULTing GRP. (Jan. 4, 2007), https://perma.cc/SY9N-CUEL.

18 Huron Consulting Group Agrees to Acquire Glass \& Associates, Inc., HURON CONSUlTiNG GRP. (Jan. 4, 2007), https://perma.cc/94FD-X37M.

19 E.g., Asset Purchase Agreement by and Among Callaway Partners and Huron $\S 13.10$ (July 28, 2007), https://perma.cc/5W9X-ZV4R. Huron is headquartered in Chicago, Illinois.
} 
noticed is that all three contracts use the same font and format, and have similarly titled provisions. ${ }^{20}$ For instance, the substantive choice-of-law provision in all three contracts is titled "Applicable Law," ${ }^{21}$ which is a rarity among these agreements. Indeed, the three agreements look like almost identical copies of one another. A study of the notice clause reveals who wrote these contracts. All acquired parties were represented by different sophisticated and successful law firms, namely Epstein, Becker \& Green, P.C.; Kirkpatrick \& Lockhart Nicholson Graham LLP (now K\&L Gates LLP); and McDermott Will \& Emery LLP. At the same time, what all three agreements have in common is the counsel representing Huron, an experienced partner of one of the largest law firms in the United States. Together, this suggests that all agreements were written based on the same template, provided by the acquirer's counsel. This template, in turn, did not include a dispute settlement clause, and so neither did any of the agreements supporting the acquisitions.

At its core, this Article is a systematic and comprehensive investigation of what is exemplified by the case of Huron. It shows that the decision whether to include a dispute settlement provision is not typically made in an effort to maximize the joint surplus of the agreement. Instead, the presence of these clauses is almost exclusively driven by the lawyers that are hired to draft the contract between the parties. And even though most of the transactions under investigation have a value of several millionor even billion-dollars, the dynamics of the deal seem not to explain the lawyers' decision to include or not include a dispute settlement clause. Instead, external counsel relies heavily on templates, and whether the final contract addresses the settlement of disputes is determined almost exclusively by the template that a law firm uses.

Exploiting the fact that some law firms collapsed during the period of observation, forcing lawyers to move to different firms and clients to seek new counsel, this Article further demonstrates that there is no evidence to suggest that companies strategically hire law firms that use the most beneficial template for their

20 Compare Asset Purchase Agreement by and Among Callaway Partners and Huron, supra note 19, with Stock Purchase Agreement by and Among Wellspring Partners and Huron (Dec. 29, 2006), https://perma.cc/K4EB-EHSV, and Stock Purchase Agreement by and Among Glass \& Associates and Huron (Jan. 2, 2007), https://perma.cc/KM75-NNKM.

21 See, e.g., Asset Purchase Agreement by and Among Callaway Partners and Huron, supra note $19, \S 13.10$. 
deals. Similarly, external variation in the default rules on forum choice seems to have no bearing on how parties approach issues of forum selection. Instead, the final contract is almost always identical to the first draft that was provided by one of the law firms. In contrast, the historical practice of the law firm receiving the first draft has no measurable bearing on whether the final contract specifies a forum. This suggests that external counsel virtually never bargains over or adapts dispute settlement clauses as found in the initial draft.

The results show that sticky drafting practices characterize the most fundamental aspects of commercial transactions across a wide range of contexts. In doing so, these results contribute to the literature on the economics of contract design and the role of the legal profession in several important ways.

First, much of modern legal and economic scholarship on contracts assumes that sophisticated parties routinely write optimal agreements. Meanwhile, the popular Coase Theorem teaches us that default rules do not matter if transaction costs are negligible, because parties would simply contract around inefficient default rules. ${ }^{22}$ Together, these assumptions have resulted in a lethargy with respect to academic, regulatory, and judicial interest in analyzing and optimizing the default rules that pertain to transactions between sophisticated commercial actors. ${ }^{23}$

The jurisprudence on the default rules of personal jurisdiction are a case in point. Over the past decade, the Supreme Court

22 See generally Ronald H. Coase, The Problem of Social Cost, 3 J.L. \& Econ. 1 (1960); see also Frank H. Easterbrook \& Daniel R. Fischel, Limited Liability and the Corporation, 52 U. CHI. L. REV. 89, 102 (1985) (suggesting that the default rules on liability can be contracted around and have no impact on the final allocation of surplus, save for transaction costs).

23 See Ian Ayres \& Robert Gertner, Filling Gaps in Incomplete Contracts: An Economic Theory of Default Rules, 99 YALE L.J. 87, 89 (1989) ("Few academics have gone beyond one-sentence theories stipulating that default terms should be set at what the parties would have wanted."). To be sure, scholars have developed a theoretical framework for how to assess the efficiency of default rules more generally. See, e.g., Charles J. Goetz \& Robert E. Scott, The Mitigation Principle: Toward a General Theory of Contractual Obligation, 69 VA. L. REV. 967, 971-86 (1983) (developing a theoretical model of optimal mitigation); Clayton P. Gillette, Commercial Relationships and the Selection of Default Rules for Remote Risks, 19 J. LEGAL STUD. 535, 562-76 (1990) (discussing the choice of optimal default rules under different commercial relationships and the signals courts receive based on the parties' choice); Robert E. Scott, A Relational Theory of Default Rules for Commercial Contracts, 19 J. LEGAL STUD. 597, 606-13 (1990) (developing a positive theory of contractual gap fillers and explaining the prevalence of generalized default rules in contracts). However, empirical analyses on whether existing default rules meet these standards are rare, making it difficult to formulate specific policy recommendations. 
has made important innovations in the legal framework surrounding dispute settlement provisions for claims directed against corporations. ${ }^{24}$ However, this jurisprudence was developed almost exclusively in the context of tort law and consumer contracts. ${ }^{25}$ At the same time, and consistent with the view that sophisticated actors are able to optimize the rules themselves, the Court has done very little to promote clarity in the at times opaque default rules on forum choice in contract disputes at arm's length. The results of this study lay bare an important practical limitation of theoretical approaches to these traditional accounts of contract design. Default rules such as those on forum choice can have important welfare implications because they affect not only the distribution, but also the final allocation of the contractual surplus. As such, it is worth spending scholarly, regulatory, and judicial attention to the design of efficient default rules even as they pertain to transactions between highly sophisticated actors.

Second, while the recent trend toward more empirical scholarship on contracts resulted in many valuable insights, one can observe a tendency for researchers to infer the efficiency of a clause from its prevalence in contracts between commercial actors. For instance, a desire to explain a seemingly incoherent set of contract terms has led to increasingly complex theoretical models explaining the interplay between formal and relational contracts. ${ }^{26}$ Only few have taken into consideration that the nuanced provisions in these contracts may not be optimized. ${ }^{27}$ The results of the study described in this Article suggest that it may be suitable to exert caution more frequently, thus determining efficiency on its own terms rather than to infer it from observed practice.

\footnotetext{
24 For a detailed discussion, see infra notes 151-70 and accompanying text.

25 See infra notes 205-06 and accompanying text.

26 See, e.g., Laura Poppo \& Todd Zenger, Do Formal Contracts and Relational Governance Function as Substitutes or Complements?, 23 STRATEGIC MGMT. J. 707, 712-16, 719-21 (2002) (showing that there is complementarity between formal contracts and relational governance); Kyle J. Mayer \& Nicholas S. Argyres, Learning to Contract: Evidence from the Personal Computer Industry, 15 ORG. SCI. 394, 396-97, 402-07 (2004) (describing the process of "learning to contract" among parties with long-term contractual relationships); David T. Robinson \& Toby E. Stuart, Network Effects in the Governance of Strategic Alliances, 23 J.L. ECON. \& ORG. 242, 269-71 (2007) (discussing the impact of network effects in interfirm relationships and transactions); David T. Robinson \& Toby E. Stuart, Financial Contracting in Biotech Strategic Alliances, 50 J.L. \& ECON. 559, 564-93 (2007) (analyzing contracts in the biotech industry).

27 E.g., Matthew Jennejohn, Disrupting Relational Contracts 42 (Feb. 13, 2018) (unpublished manuscript) (on file with author) (controlling for the two most important law firms in an analysis of contractual relationships for pharmaceutical alliances).
} 
Third, this Article adds to and expands on the growing body of literature that emphasizes the significance of the law firm's role in the allocation of contractual rights. Prior research has found that the law firm is an important actor in explaining the design of pari passu clauses in sovereign bond agreements, ${ }^{28}$ the prevalence of arbitration provisions in these contracts, ${ }^{29}$ exclusive forum provisions in corporate charters and bylaws, ${ }^{30}$ takeover defenses, ${ }^{31}$ and the language of S-1 statements filed in the course of initial or secondary public offerings. ${ }^{32}$ However, law firms do not seem to matter for the formulation of event risk covenants in corporate bonds when controlling for the underwriter. ${ }^{33}$ The study described in this Article is the first to investigate the influence of the law firm in a wide array of contractual relationships at arm's length, overcoming the problem of a lack of generalizability that affects previous contributions. It is also the first Article to compare the law firm's influence to that of the company by considering another important legal actor, the general counsel.

Finally, heterogeneity in contractual drafting practices suggests an important domain in which legal education can be value enhancing. In particular, by raising awareness of and advising their students on the pitfalls of template-driven contract drafting, law schools can enable students to significantly improve the distribution of contractual rights in favor of their clients.

This Article proceeds in seven parts. Part I offers a brief primer on the laws surrounding forum choice and dispute settlement

28 See, e.g., Mitu Gulati \& Robert E. Scott, The Three And a Half Minute Transaction: Boilerplate AND the Limits of Contract Design 121-24 (2013); Stephen J. Choi, Mitu Gulati \& Eric A. Posner, The Evolution of Contractual Terms in Sovereign Bonds, 4 J. LEgal ANALYsis 131, 143-46 (2012); Stephen J. Choi, Mitu Gulati \& Eric A. Posner, The Dynamics of Contract Evolution, 88 N.Y.U. L. REV. 1, 15-17 (2013) [hereinafter Choi et al., The Dynamics of Contract Evolution]; Stephen J. Choi, Mitu Gulati, \& Robert E. Scott, The Black Hole Problem in Commercial Boilerplate, 67 DuKE L.J. 1, 1724, 43-44 (2017) [hereinafter Choi et al., The Black Hole Problem].

29 E.g., Karen Halverson Cross, Arbitration as a Means of Resolving Sovereign Debt Disputes, 17 AM. REV. INT'L ARB. 335, 374-77 (2006).

30 E.g., Roberta Romano \& Sarath Sanga, The Private Ordering Solution to Multiforum Shareholder Litigation, 14 J. EMPIRICAL LEGAL STUD. 31, 50-76 (2017).

31 E.g., John C. Coates IV, Explaining Variation in Takeover Defenses: Blame the Lawyers, 89 CALIF. L. REV. 1301, 1377-83 (2001).

32 E.g., Adam B. Badawi, Lawyers, Law Firms, and the Production of Legal Knowledge 4-9 (Oct. 9, 2017) (unpublished manuscript) (on file with author).

33 Marcel Kahan \& Michael Klausner, Standardization and Innovation in Corporate Contracting (or "The Economics of Boilerplate"), 83 VA. L. REV. 713, 753-54, 75960 (1997) (finding that law firms exert no measurable influence on the language in event risk covenants). 
clauses. Part II describes two theoretical approaches to the study of contract design and develops competing predictions on how contracts should be drafted. Part III introduces the data set and presents summary statistics. Part IV investigates whether the contracts in the data set reflect law firm or company preferences. Part V asks whether law firms ever bargain over the issue of forum choice. Part VI analyzes how resistant law firm templates are to changing circumstances in the legal environment. Finally, Part VII discusses limitations and the implications of the findings for the study and design of contracts.

\section{A BRIEF PRIMER ON ForUM CHOICE}

In order for a court to exercise authority in a case, it requires personal jurisdiction over the defendant. Personal jurisdiction is established either by law or by voluntary submission of the defendant. Through the use of forum selection clauses (or "choiceof-forum clauses"), parties can opt to submit to a particular court's jurisdiction ex ante, i.e., before the dispute arises. Forum selection clauses can be narrow in scope, such that they pertain to a limited subset of contractual claims. In contrast, broad clauses affect all disputes arising out of the contractual relationship between the parties and may even encompass tort and statutory claims. ${ }^{34}$

Choice-of-forum provisions can be either permissive or exclusive. A permissive clause bars the defendant from challenging a court's jurisdiction. However, the plaintiff may still pursue litigation in a forum other than the one specified in the clause. Permissive choice-of-forum clauses are thus strictly beneficial to the plaintiff. In contrast, exclusive choice-of-forum provisions not only bar the defendant from challenging a court's personal jurisdiction, but also allow her to transfer any dispute to the court that

34 Clauses that cover tort and statutory claims often use broad language. Typically, these clauses refer to the courts any dispute "arising out of the relationship" of the parties or that is "related to," "in regards to," or "in connection with" their transaction. See, e.g., Manetti-Farrow, Inc. v. Gucci Am., Inc., 858 F.2d 509, 514 (9th Cir. 1988) (holding that disputes "regarding interpretation or fulfillment" of a contract encompasses tort claims) (quotation marks omitted). Some courts have a tendency to interpret all forum selection clauses broadly. See TriState HVAC Equip., LLP v. Big Belly Solar, Inc., 752 F. Supp. 2d 517, 536 (E.D. Pa. 2010) ("[C]ourts have generally held that a forum-selection clause applies to tort and other non-contract claims that require interpretation of the contract or otherwise implicate the contract's terms."); see also John F. Coyle, Interpreting Forum Selection Clauses, 104 IOWA L. REV. 1791, 1803-19 (2019) (discussing the scope of interpretation for forum selection clauses). 
is specified in the provision. As such, exclusive choice-of-forum clauses are both enabling and disabling to the plaintiff.

In addition to choosing the court that hears their case, parties also have the option to refer disputes to private arbitration. ${ }^{35}$ In principal, arbitration allows parties to customize procedural rules with great flexibility. In practice, however, many parties opt for commoditized, structured arbitral proceedings as they are offered by a few large arbitral organizations, such as the American Arbitration Association or JAMS. ${ }^{36}$ In doing so, the active choices of the parties are often reduced to picking the arbitrators and specifying the seat and venue of the arbitral proceedings. The seat determines the jurisdiction that parties can turn to if they seek judicial intervention, e.g., if they want an arbitral award to be set aside or annulled. The venue determines the physical location of the arbitral proceedings. Parties can also choose to submit some claims to courts, while leaving others to arbitration. For instance, in M\&A contracts, disputes surrounding the adjustment of the purchase price due to a change in the value of the acquired company are often subjected to the evaluation of a private expert, such as an independent accounting firm.

To avoid confusion, it should be noted that this Article uses the term "dispute settlement clause" or "dispute resolution provision" to refer to the collective of both clauses referring parties to courts, as well as those referring them to arbitration.

If the parties leave the forum unspecified, the default rules determine whether a court has personal jurisdiction over the defendant. Under complete diversity, it is possible for both federal and state courts to exert jurisdiction over the defendant. Within each court system, the rules by which courts can exert personal jurisdiction in any given dispute are not conclusive and overall lack clarity, especially in the period under study here. Nonetheless, one can try to formulate a few broad principles that apply to company contracts of the type under investigation.

Principally, states have an interest in holding residents and nonresidents accountable if they perform certain acts that have

35 Parties can also opt for mediation. However, mediation is a consensus-based dispute resolution process that complements, rather than replaces, adversarial and binding means of dispute settlement. This Article is focused on binding means of dispute resolution and thus does not consider mediation.

36 Nyarko, supra note 14, at 13 tbl.4 (finding that $60 \%$ of SEC contracts opt for arbitration under the American Arbitration Association, JAMS, the International Chamber of Commerce, or the China International Economic and Trade Arbitration Commission). 
repercussions within the state. This interest has to be balanced against the parties' interest in not being subjected to litigation in a forum to which they have no relevant "contacts, ties, or relations." ${ }_{7}$ This has effectively led to the implementation of a test by which states can exert jurisdiction over a defendant if the defendant has "minimum contacts" with the state. ${ }^{38}$ The contacts necessary to satisfy the "minimum contacts" requirement vary based on whether personal jurisdiction is asserted under principles of general or specific jurisdiction.

A court with general jurisdiction over a defendant can hear any case against that defendant, irrespective of the specific cause of action. Courts all over the country have long differed in the level of intensity of the relationship between a company and the state that is sufficient to establish general jurisdiction. The most expansive view is expressed in the "doing business" test. Under that test, it is sufficient for a company to do business "with a fair measure of permanence and continuity" in a state in order for the courts in that state to exert general jurisdiction. ${ }^{39}$ A recent line of Supreme Court decisions, which will be discussed in detail below, ${ }^{40}$ has decreased the expansive "doing business" test to the more narrow "essentially at home" test, which limits general jurisdiction over a company to its place of incorporation and its principal place of business.

Specific jurisdiction over a defendant is based on the particular action that gives rise to the claim. To define what constitutes "minimum contacts" with regard to specific jurisdiction, most states have enacted so-called long-arm statutes. ${ }^{41}$ Typically, these statutes provide that jurisdiction may be asserted by transacting business in a state, contracting to supply products or services within a state, or even by failing to perform contractually required acts in a state. ${ }^{42}$ Other characteristics that factor into the analysis in contract disputes, while not necessarily sufficient

37 Int'l Shoe Co. v. Washington, 326 U.S. 310, 319 (1945).

Id. at 316 .

See, e.g., Tauza v. Susquehanna Coal Co., 115 N.E. 915, 917 (N.Y. 1917).

40 See infra notes $152-56$.

41 In New York, for instance, the long-arm statute is N.Y. C.P.L.R. $§ 302$ (McKinney 2008).

42 See FLA. STAT. § 48.193(1)(a) (2016) ("A person . . . submits himself or herself . . to the jurisdiction of the courts of this state for any cause of action arising from ... [b]reaching a contract in this state by failing to perform acts required by the contract to be performed in this state.”). 
independently, are the place of contract negotiations, ${ }^{43}$ place of performance, ${ }^{44}$ place in which payments are to be made, ${ }^{45}$ and the choice-of-law provision. ${ }^{46}$

The Supreme Court has always upheld the validity of longarm statutes, ${ }^{47}$ though its last decision dates back to $1985 .{ }^{48}$ As such, there are few universally applicable guidelines for parties to project the risk of being subjected to litigation in a particular forum, and the principles by which personal jurisdiction is established vary significantly.

This uncertainty is further amplified by a tendency of some courts to not cleanly distinguish between the requirements for general and specific jurisdiction in contracts cases. As Professor Charles Rhodes points out, general jurisdiction-if fully embraced by the courts-is "dispute-blind," such that a breach of contract claim between a company registered in California and one registered in Pennsylvania could be litigated in Texas simply by virtue of the defendant having substantial business ties in the state, even though the contract has no other relations to Texas. 49 In practice, however, some courts distinguish between general and specific jurisdiction simply based on the quantity of forum contacts. In these jurisdictions, pursuing a claim arising out of a breach of contract always requires some connection between the contract and the state, even under general jurisdiction. For these

43 See, e.g., PVC Windoors, Inc. v. Babbitbay Beach Const., N.V., 598 F.3d 802, 81112 (11th Cir. 2010) (considering, but ultimately rejecting, the sufficiency of the place of contract negotiations); Kelly v. MD Buyline, Inc., 2 F. Supp. 2d 420, 431-32 (S.D.N.Y. 1998) (finding that negotiation and rendering legal services in New York is sufficient to establish jurisdiction).

44 See Jones v. Petty-Ray Geophysical Geosource, Inc., 954 F.2d 1061, 1068 (5th Cir. 1992) ("[T]his Court has consistently looked to the place of contractual performance to determine whether the making of a contract with a Texas resident is sufficiently purposeful to satisfy minimum contacts.").

45 See, e.g., Glob. Satellite Commc'n Co. v. Sudline, 849 So. 2d 466, 468 (Fla. Dist. Ct. App. 2003).

46 See, e.g., N. Coast Com. Roofing Sys., Inc. v. RMAX, Inc., 130 S.W.3d 491, 495 (Tex. App. 2004). Note again, however, that a choice-of-law provision alone may be insufficient to establish jurisdiction. See Preussag Aktiengesellschaft v. Coleman, 16 S.W.3d 110, 125 (Tex. App. 2000); see also Sunward Elecs., Inc. v. McDonald, 362 F.3d 17, 22 (2d Cir. 2004) (establishing a four-factor test).

47 See generally Hanson v. Denckla, 357 U.S. 235 (1958); McGee v. Int'l Life Ins. Co., 355 U.S. 220 (1957); Int'l Shoe, 326 U.S. 310.

48 See generally Burger King Corp. v. Rudzewicz, 471 U.S. 462 (1985).

49 Charles W. "Rocky" Rhodes, The Predictability Principle in Personal Jurisdiction Doctrine: A Case Study on the Effects of a "Generally" Too Broad, but "Specifically" Too Narrow Approach to Minimum Contacts, 57 BAYLOR L. REV. 135, 153 (2005) (discussing the degree to which courts embrace general jurisdiction). 
reasons, commentators have argued that, in some states, general jurisdiction is merely a "myth," with courts essentially employing the same analysis as required under specific jurisdiction. ${ }^{50}$

What can then be taken away from this description of the default rule is that it induces uncertainty in contracting parties with respect to the particular court that will hear their case. In contracts between large public companies, the place of negotiations, place of performance, state of registration, principal place of business, and other provisions all might diverge, potentially subjecting the parties to litigation in multiple court forums, as exemplified by the Sprint-Nextel merger case in the Introduction.

\section{PARTY PREFERENCES AND STICKINESS}

A study of over three million federal civil cases between 1979-1991 conducted by Professors Kevin Clermont and Theodore Eisenberg showed that, on average, there is almost one 28 U.S.C. § 1404(a) (change of venue) motion for each federal civil trial. ${ }^{51}$ The finding suggests that, even within the relatively homogenous federal court system, litigators assign great importance to the question which specific court hears their case. In addition, among all 557,014 relevant contracts cases, the probability for the plaintiff to win was $82 \%$ if the case was not transferred through a change of venue motion (and the venue thus reflects the preferences of the plaintiff). In contrast, if the case was decided pursuant to a successful $\S 1404$ (a) motion, the venue is more likely to reflect the defendant's preferences, and the probability for the plaintiff to win drops to only 54\%.52 Though it is necessary to exert some caution when interpreting this difference, ${ }^{53}$

50 Mary Twitchell, The Myth of General Jurisdiction, 101 HARV. L. REV. 610, 617 (1988).

51 Kevin M. Clermont \& Theodore Eisenberg, Exorcising the Evil of Forum-Shopping, 80 CORNELL L. REV. 1507, 1509 n.3, 1525-30 (1995) (estimating about ten thousand transfer motions per year, compared to eleven thousand trials).

52 I calculate this number based on the contracts cases which are of most relevance to this study, as depicted in Clermont and Eisenberg's Appendix, see id. at 1531. After subsetting to all contracts cases, I further drop from the analysis cases from the following subcategories due to their lack of relevance: "Indemnity on Admiralty Cases," "Recovery of Medicare Overpayments," "Recovery of Defaulted Student Loans," "Recovery of Overpayment of Veterans Benefits," "Hospital Care Act," and "Contract Product Liability." However, the results are similarly striking when considering all 834,667 contracts cases ( $89 \%$ versus $57 \%)$.

53 Only a small fraction of cases goes to judgment, making it possible that selection effects through settlement rates explain some of the observed differences. For instance, it is possible that plaintiffs with a weak case are more likely to try their luck and shop for extravagant forums, only to be subjected to a successful motion of venue transfer, whereas 
it may suggest that the litigators' interest in the choice of forum is well founded, as it can have a profound impact on the outcome of the suit.

In light of this evidence and uncertainty associated with the default rule, why is it the case that over half of all material contracts submitted to the SEC lack a dispute settlement provision?

Traditional contract theory assumes that sophisticated actors routinely write optimized agreements, and that the presence or absence of a clause is primarily driven by the costs and benefits conferred upon the parties, ${ }^{54}$ a view that is also held by the courts. ${ }^{55}$ Indeed, some commentators even argue that a belief in the ability of parties to maximize the contractual surplus is so deeply entrenched in the mindset of judges that it would be able to explain the vast majority of judicial reasoning and jurisprudence in contract law. ${ }^{56}$

plaintiffs with a strong case have fewer incentives to shop for forums with a low probability to deny venue transfer. This would mean that the true effect of the forum may be smaller than a simple comparison may suggest. At the same time, there are also reasons to assume that the true and full effect of forum choice on substantive outcomes may be larger. After all, a venue transfer under $\S 1404$ (a) is the "mildest" form of forum shopping that parties can engage in. That is because district courts all apply the same procedural law, leading to some homogeneity between the different venues. An omission of a forum selection clause potentially allows plaintiffs to select not only between different courts of the federal system, but also between the state and federal judiciary (assuming complete diversity), as well as between different state courts. It is at least conceivable that the relevance of the forum and venue for the outcome, as suggested by Clermont \& Eisenberg, supra note 51, merely provides a lower bound, and that the omission of a choice-of-forum clause might have even more pronounced consequences in other cases where the parties shop not only within the federal courts, but also between different types of adjudicatory systems.

54 For seminal works, see generally Oliver Hart \& Bengt Holmström, The Theory of Contracts, in ADVANCES IN ECONOMIC THEORY 71 (Truman Fassett Bewley ed., 1987); Richard A. Posner, The Law and Economics of Contract Interpretation, 83 TEX. L. REV. 1581 (2005); RICHARD A. POSNER, ECONOMIC ANALYSIS OF LAW (9th ed. 2014).

55 In discussing the importance of a forum selection clause between two commercial actors, with one party alleging that the forum selection clause was boilerplate language that the parties did not reflect upon, Justice Warren Burger contended: "[I]t would be unrealistic to think that the parties did not conduct their negotiations, including fixing the monetary terms, with the consequences of the forum clause figuring prominently in their calculations.” The Bremen v. Zapata Off-Shore Co., 407 U.S. 1, 14 (1972). Similarly, Judge Richard Posner has described it as "(at best) paternalistic" and "odd" for a court to question the validity of a penalty clause that sophisticated parties have included in a contract, presuming that it has been bargained for. Lake River Corp. v. Carborundum Co., 769 F.2d 1284, 1289 (7th Cir. 1985).

56 Jody P. Kraus \& Robert E. Scott, The Case Against Equity in American Contract Law, 93 S. Cal. L. Rev. (forthcoming 2020) (manuscript at 24-25):

[V]irtually all of the American common law of contracts derives from two premises: the purpose of contract law is to enforce the parties' ex ante intent and most parties intend to maximize the expected value of their contracts at the time they 
At the same time, the literature on dispute resolution has not produced a theory that predicts parties will not include dispute settlement clause in their contracts. Instead, it is assumed that the cost-benefit calculus necessarily comes out in favor of inclusion, with the only remaining question being the type of clause that should be included. For instance, scholars have asked whether, and under what circumstances, parties prefer arbitration over courts, ${ }^{57}$ and how parties should design efficient procedural rules. ${ }^{58}$ In order to establish a baseline rate of dispute resolution clause usage under the null hypothesis that stickiness plays no role in contract drafting, it is worth revisiting the assumption of universal desirability by examining the potential costs and benefits of including such a clause.

\section{A. Dispute Resolution Clauses: The Benefits}

\section{Decreased litigation costs.}

Perhaps the most obvious benefit resulting from the inclusion of a dispute resolution provision is decreased litigation costs. As mentioned above, ${ }^{59}$ litigators perceive the forum as an important determinant for the outcome of the dispute and are willing to fight over it fiercely. Litigation over where to litigate can cost the parties significant time and-in the form of lawyer fees-

form them.... [These foundational premises] serve[] as the cornerstone of a genuine interpretive theory of American contract law.

But see, e.g., Stephen A. SMith, Contract Theory 31 (2004) (arguing that utilitarian considerations are orthogonal to legal reasoning); Ronald M. Dworkin, Is Wealth a Value?, 9 J. LEGAL STUD. 191, 219-20 (1980) (claiming that the "normative limb" of joint value maximization calls into question its descriptive accuracy).

57 See Steven Shavell, Alternative Dispute Resolution: An Economic Analysis, $24 \mathrm{~J}$. LEGAL STUD. 1, 5-7 (1995) (discussing the benefits of alternative dispute resolution mechanisms); Robert G. Bone, Party Rulemaking: Making Procedural Rules Through Party Choice, 90 TEX. L. REV. 1329, 1355-69, 1372-84 (2011) (considering arguments on the costs and benefits of including an arbitration clause vis-à-vis litigation); Jaime Dodge, The Limits of Procedural Private Ordering, 97 VA. L. REv. 723, 739-42 (2011) (describing incentives for choosing a forum and surveying empirical evidence for the strategic inclusion of choice-of-forum provisions).

58 See, e.g., Robert E. Scott \& George G. Triantis, Anticipating Litigation in Contract Design, 115 YALE L.J. 814, 856-57 (2005) (discussing the implications that future litigation has on the optimal design of contracts); Bone, supra note 57, at 1380-84 (providing a holistic theoretical framework in which to consider the costs and benefits of procedural customization rooted in a utilitarian framework); Daphna Kapeliuk \& Alon Klement, Changing the Litigation Game: An Ex Ante Perspective on Contractualized Procedures, 91 TEX. L. REV. 1475, 1483 (2012).

59 Supra notes 51-53 and accompanying text. 
considerable resources. In addition, these disputes can have substantial indirect costs, as exemplified by the case of the SprintNextel merger, when multiforum litigation increased the uncertainty surrounding the legality of the merger, forcing Sprint to buy out most of its affiliates.

2. Efficient performance.

Including a dispute settlement provision can further incentivize the parties' efficient performance with the contractual terms. In the Appendix, ${ }^{60} \mathrm{I}$ formally develop this argument by introducing an extension to a standard model of forum choice by Professors Steven Shavell, ${ }^{61}$ Christopher Drahozal, and Keith Hylton. ${ }^{62}$ To develop a nonformal intuition for this result, consider that the parties' incentive to breach a contract is related to the costs they face for the breach. These costs generally come in the form of dispute settlement expenses and damages awarded by the court. A party contemplating a breach of contract may be deterred if it predicts that its breach will subsequently be litigated in a jurisdiction in which litigation is cheap ${ }^{63}$ and damage awards are high.

Both expected dispute settlement expenses and damages vary from one jurisdiction to the other. This is certainly true for the difference in expenses between litigation and arbitration, provided that parties only bear the full costs of their disputes in arbitration. Indeed, studies indicate that about $20 \%$ of the total costs of complex arbitral proceedings are paid to the arbitration institution and the arbitrators. ${ }^{64}$ In the domestic court system, this amount is largely subsidized by the public. But even within forums of a particular type, costs can vary substantially. For

60 Infra Part A.I.

61 See generally Shavell, supra note 57.

62 See generally Keith N. Hylton, Agreements to Waive or to Arbitrate Legal Claims: An Economic Analysis, 8 SuP. CT. ECON. REV. 209 (2000); Christopher R. Drahozal \& Keith N. Hylton, The Economics of Litigation and Arbitration: An Application to Franchise Contracts, 32 J. LEGAL STUD. 549 (2003). But cf. Dodge, supra note 57, at 756-57 (arguing that the standard model is "a useful but imprecise heuristic," and noting that suboptimal terms could still result from the particularities of the bargaining dynamics, such as discrepancies in bargaining power).

63 It does not have to be cheap in a monetary sense. For instance, a jurisdiction in which courts have a small docket of pending cases may also be attractive for plaintiffs. See InT'L Chamber of COMmerce, Publication 843, TEChNiques For Controlling Time AND COSTS IN ARBITRATION (2007).

64 For survey data, see Costs of International Arbitration Survey 2011, CIARB (Sept. 27, 2011), https://perma.cc/G4DJ-89DC. 
example, most corporate legal firms have a significant presence in and familiarity with the courts of New York, lowering the costs for disputes litigated in the state, compared to litigation in a state that corporate lawyers are much less familiar with. Further, different states have different procedural laws, which, in turn, alter their costs. For example, it is well known that civil jury trials on average take twice as long as bench trials, ${ }^{65}$ but that not all states enforce jury waiver clauses, which potentially exposes parties to longer and more costly litigation. ${ }^{66}$ In addition to dispute settlement costs, damage awards can also vary with the dispute settlement mechanism and forum. Again, the most significant difference exists between courts and arbitration, where some evidence suggests that arbitrators might be susceptible to granting awards that split the baby to maximize their chances of reappointment. ${ }^{67}$ But even within the domestic judiciary, awarded damages can vary, for example, because of differences in the pool of juries or judges. 68

Parties that choose their dispute settlement mechanism have the possibility to optimize the incentives provided in order to guarantee that a contract is only breached if it is efficient to do so. Parties that do not agree on a dispute settlement provision forego this possibility, allowing plaintiffs to unilaterally choose forums that are particularly favorable to their claim. Whether the expected dispute settlement expenses and damages awarded in

65 See Posner, supra note 54, at 816-21; see also J.S. KAKALIK \& R.L. Ross, Costs of the Civil Justice System, at xi-xv (1983); DAle A. SiPES \& MARY Elsner ORAM, ON TRIAL: THE LENGTH OF CIVIL AND CRIMINAL TRIALS 12-15 (1988).

66 In North Carolina, jury waiver clauses are unenforceable by statute. See N.C. GEN. STAT. § 22B-10 (1993). California and Georgia courts often hold them unconscionable as a matter of common law. See Grafton Partners, L.P. v. Superior Court, 116 P.3d 479, 481 (Cal. 2005); Bank South v. Howard, 444 S.E.2d 799, 800 (Ga. 1994). Even those states that enforce jury waivers often invoke a presumption against the enforceability of a waiver, limiting enforcement to those clauses that are narrowly construed. See Posner, supra note 54 , at 1595 . Note that, generally, the validity of a jury waiver clause is a procedural question that is to be decided under procedural rules. However, the Ninth Circuit has held that, where state law is more protective of jury waivers, federal courts may import the standard of the substantive state law that governs the contract. See In re County of Orange, 784 F.3d 520, 524 (9th Cir. 2015).

67 See Henry S. Farber \& Max H. Bazerman, The General Basis of Arbitrator Behavior: An Empirical Analysis of Conventional and Final-Offer Arbitration 7-10 (Nov. 1984) (Nat'l Bureau of Econ. Rsch. working paper); see also Jens Dammann \& Henry Hansmann, Globalizing Commercial Litigation, 94 CORNELL L. REV. 1, 34 (2009). But see generally Ana Carolina Weber, Carmine A. Pascuzzo S., Guilherme de Siqueira Pastore \& Ricardo Dalmaso Marques, Challenging the "Splitting the Baby" Myth in International Arbitration, 31 J. INT'L ARB. 719 (2014) (providing contradicting evidence).

68 See, e.g., Drahozal \& Hylton, supra note 62, at 558-62. 
the jurisdiction chosen by the plaintiff unilaterally exceed those awarded by the court or arbitrator that is chosen ex ante by mutual agreement cannot be determined generally. On one hand, it is evident that the plaintiff will have an interest to choose a forum that is particularly favorable to her claims. On the other hand, not choosing the forum ex ante significantly diminishes the set of jurisdictions in which the plaintiff can sue absent consent by the defendant, such that the plaintiff's options are severely limited. However, what should be noted is that only in exceptional circumstances will the plaintiff's choice of jurisdiction provide efficient incentives to the defendant. In all other cases, the defendant may be over- or underdeterred, leading to an expected welfare loss for the contractual parties.

\section{Aligning forum and substantive law.}

Lastly, benefits are conferred on parties who align the substantive law governing the contract with the courts that will hear their disputes. As Thomas McClendon notes, courts have a competitive advantage in deciding their own state law, one that stems from their familiarity with the applicable rules. ${ }^{69}$ That divergences between the choice-of-law and choice-of-forum are undesirable is further supported both by the data presented here, as well as by interviews conducted with transactional attorneys. As Table 4 demonstrates, contracts that specify both a governing law and a court forum hardly ever create a dispute resolution process in which courts apply a law from another state. In addition, interviews have shown that aligning the substantive law and forum are among the primary considerations governing the drafters' choice between different forums. ${ }^{70}$ However, if parties do not specify a forum, the chance for the substantive law to differ from the forum increases significantly, making the outcome less predictable and potentially longer due to the unfamiliarity of the judges. Again, the Sprint-Nextel merger provides an illustrative case,

69 Thomas T. McClendon, Note, The Power of a Suggestion: The Use of Forum Selection Clauses by Delaware Corporations, 69 WASH. \& LEE L. REV. 2067, 2079-80 (2012).

70 Matthew D. Cain \& Steven M. Davidoff, Delaware's Competitive Reach, 9 J. EMPIRICAL LEGAL STUD. 92, 98 (2012) ("In terms of driving factors for the choice of forum decision, choice of law is often viewed by attorneys as being the most important. This allows for a jurisdiction familiar with the law chosen to actually adjudicate any disputes thereunder."). 
where a Delaware court applied the substantive law of Pennsylvania, further amplifying the complexities of the dispute. ${ }^{71}$

\section{B. Dispute Resolution Clauses: The Costs}

\section{Negotiation and drafting costs.}

Perhaps the most evident costs associated with the inclusion of dispute settlement provisions are the costs of negotiations and drafting. Because the forum can have a significant impact on the outcome of a potential dispute, it is possible that any attempt for one party to include its preferred forum would be met by fierce opposition. It might then be best for the parties to leave the forum unspecified in hopes that a dispute does not occur between them. And even if parties can agree on a preferred forum, provisions still have to be drafted. Drafting could cost the parties significant resources, even though those can be mitigated through the inclusion of boilerplate language.

However, while comprehensive data on negotiation and drafting costs do not exist, available evidence suggests that these costs are negligible. In particular, a 2014 survey of general counsel in the Public Utility, Communications, and Transportation (PUCAT) industries conducted by the American Bar Association suggests that parties typically spend less than one hour negotiating and drafting dispute settlement provisions in "significant commercial contracts," implying that their direct costs do not exceed $\$ 5,000.72$ This is consistent with other survey evidence in which drafters describe dispute settlement provisions as "2am clause[s]" that are included without much negotiation after the substantive terms of the contract have been determined..$^{73}$

71 See UbiquiTel Inc. v. Sprint Corp., No. Civ.A. 1489-N, 2005 WL 3533697, at *5 (Del. Ch. Dec. 14, 2005)

72 Fifty-nine percent of respondents said that their company allots less than one hour on the negotiation of dispute resolution clauses, and eighty-two percent spend less than four hours. See JoHn JAY RANGe ET AL., FALL 2014 REPORT OF THE ALteRnATIVE DisPUTE RESOlution COMMITTEE ON ITS ADR SURVEY OF COMPANIES IN PUCAT INDUSTRIES 8 (2014). Even if the most senior partners were to negotiate dispute resolution clauses, their costs would not exceed $\$ 5,000$ per company. This assumes an hourly rate of $\$ 1,500$. See Martha Neil, Top Partner Billing Rates at BigLaw Firms Approach \$1,500 per Hour, ABA J. (Feb. 8, 2016), https://perma.cc/B47L-BBD8.

73 PAUl FRIEDLAND \& LOUKAS Mistelis, 2010 InTERNATIONAL ARBitration SurveY: Choices in InTERnAtional ARBITRATION 10 (2010). Drafters with whom I discussed the results of this study similarly suggested that dispute settlement provisions are not fiercely negotiated over. 
2. Negative signaling.

Another potential cost associated with the inclusion of dispute resolution clauses is negative signaling. Because a contractual gap raises the ex post costs of dispute settlement, those who bring up the issue of dispute settlement during contract negotiations could convey to the other side that there is a significant probability for a dispute to arise. Conversely, not specifying the settlement mechanism ex ante may indicate trustworthiness and provide assurances that any dispute can be solved amicably between the parties. ${ }^{74}$

This argument, however, is only somewhat plausible in the context of dispute resolution clauses. As mentioned above, these provisions do not have to be exclusive, but can also be nonexclusive. Nonexclusive choice-of-forum provisions are strictly beneficial to the potential plaintiff, as they extend the set of jurisdictions she can sue in. Hence, rather than leaving the forum unspecified, a contractual partner seeking to indicate trustworthiness has an incentive to include nonexclusive choice-of-forum provisions that confer personal jurisdiction on courts that are particularly unfavorable to her claims. In addition, one of the central functions of contracts is to allocate risks and contingencies between the parties. It is thus true that virtually any provision in a contract conveys some form of private information. However, we see much less heterogeneity in some of these other terms. For instance, most contracts include a choice-of-law clause, even though specifying the substantive law governing the contract may have stronger implications for the parties' future behavior than forum choice. Lastly, in interviews I conducted in the context of this study, both senior drafters and general counsel have described signaling costs as an "academic" concern that bears no relevance in practice.

\section{Relational contracting.}

It has been argued that some dimensions of contractual relationships should remain informal because formalizing them

74 See, e.g., Robert H. Gertner \& Geoffrey P. Miller, Settlement Escrows, 24 J. LEGAL STUD. 87, 119 (1995) (“[B]ringing up dispute resolution procedures when negotiating a contract may be a signal ... of the likelihood that a claim will arise through breach of contract."); see also Omri Ben-Shahar \& John A.E. Pottow, On the Stickiness of Default Rules, 33 FLA. ST. U. L. REV. 651, 660-63 (2005) (proposing that deviating from a contractual template may signal information that negatively affects the deviating party). 
damages the relationship between the parties. ${ }^{75}$ For instance, based on interviews with sixty-eight individuals from business and law, Professor Stewart Macaulay notes that "[d]isputes are frequently settled without reference to the contract. ... There is a hesitancy to speak of legal rights or to threaten to sue in these negotiations." 76 If true, it may be the case that those who indicate reliance on dispute settlement mechanisms risk formalizing their relationship and foregoing the advantages that come with trust. However, again, it is not immediately obvious why a similar argument should not apply to other clauses, such as choice-of-law provisions, as well.

4. Uncertainty as a screening device.

Lastly, commentators have argued that, under specific circumstances, parties may prefer uncertainty in a contract over the certainty of definitive terms and contractual language. ${ }^{77}$ The intuition behind this result is that uncertain terms that spur costly litigation present a form of ex post screening that separates claimants with strong claims from those with weak claims, potentially increasing the overall surplus of the contract. In addition, costly litigation may incentivize beneficial renegotiation of the contract. Note that, similar to the benefits conferred through efficient performance, this argument does not presuppose that parties actually litigate. Bargaining in the shadow of costly litigation

75 See Mark Granovetter, Economic Action and Social Structure: The Problem of Embeddedness, 91 AM. J. SocIO. 481, 489, 496 (1985) (characterizing formal rules as substitutes for trust); Jeffrey H. Dyer \& Harbir Singh, The Relational View: Cooperative Strategy and Sources of Interorganizational Competitive Advantage, 23 ACAD. MGMT. REV. 660, 671 (1998) (indicating that substituting formal for informal means of commitments can produce greater relational rents); Ranjay Gulati, Does Familiarity Breed Trust? The Implications of Repeated Ties for Contractual Choice in Alliances, 38 ACAD. MGMT. J. 85, 95 (1995) (discussing how highly detailed contracts could be perceived as insulting the relationship); Paul S. Adler, Market, Hierarchy, and Trust: The Knowledge Economy and the Future of Capitalism, 12 ORG. SCI. 215, 219 (2001) ("Trust can dramatically reduce both transaction costs-replacing contracts with handshakes-and agency risks-replacing the fear of shirking and misrepresentation with mutual confidence.").

76 Stewart Macaulay, Non-Contractual Relations in Business: A Preliminary Study, 28 AM. SocIO. REV. 55, 61 (1963).

77 Albert Choi \& George Triantis, Strategic Vagueness in Contract Design: The Case of Corporate Acquisitions, 119 YALE L.J. 848, 881-96 (2010) [hereinafter Choi \& Triantis, Strategic Vagueness] (discussing the efficiency of contract vagueness); Albert Choi \& George Triantis, Completing Contracts in the Shadow of Costly Verification, 37 J. LEGAL STUD. 503, 517-20 (2008) [hereinafter Choi \& Triantis, Completing Contracts] (analyzing the role of verification and litigation costs as a screening and deterrence device). 
may be able to increase the contractual surplus without the parties ever going to court. ${ }^{78}$

One may be inclined to argue that this rationale provides another reason for why parties omit a dispute settlement provision. After all, it was pointed out above that the uncertainty associated with leaving the forum unspecified can spur litigation over where to litigate. If high litigation costs are indeed desirable, then omitting a dispute resolution clause may further parties' interests by increasing litigation costs. However, the flexibility granted to parties in designing their dispute settlement provisions makes this argument only partially compelling. Assume, for instance, that the default rules allow parties to litigate in New York and that litigating in New York is cheap because both parties are incorporated and conduct their business in the state. If the goal is to increase litigation costs in order to deter weak claims and promote renegotiation, the parties could simply opt for the exclusive jurisdiction of another, less competent, more costly, and geographically more distant jurisdiction. Indeed, only if we assume that the expected costs of omitting the dispute resolution clause exceed those of litigating in the most expensive jurisdiction, it is conceivable that parties' optimal strategy is to not include any clause at all.

$$
* * *
$$

Overall, including a dispute settlement provision may create a number of different costs and benefits. While in most instances, it is reasonable to assume that parties would want to specify the forum ex ante, it is at least plausible that under some particular circumstances, a cost-benefit calculation suggests that the costs of inclusion outweigh the benefits. Hence, even under the baseline assumption that dispute settlement provisions reflect party preferences, we may observe some heterogeneity in their adoption.

\section{Law Firms and Contractual Stickiness}

Traditional theory, and with it the preceding discussion, views contractual parties as unitary actors and the costs and benefits to these unitary actors as determinative for contractual design. But more recently, this view has been challenged by a group of legal scholars. Through a series of empirical studies focusing primarily on covenants in corporate and sovereign bonds, they

78 See, e.g., Choi \& Triantis, Completing Contracts, supra note 77, at 519-20 (describing a contract in which litigation lies off the equilibrium path). 
show that many high-value contracts are not merely a reflection of the costs and benefits conferred upon the parties. ${ }^{79}$ Instead, they argue that the contractual drafting process is "sticky."

At its most fundamental level, stickiness simply describes path dependence. That is, whether a certain provision is included in the contract depends on whether said provision has been included in previous agreements. Note that some level of path dependence is perfectly consistent with traditional theory. After all, negotiating each term in an agreement can impose high transaction costs, so parties might benefit from using standardized (or "boilerplate") agreements. ${ }^{80}$ However, where the stickiness literature goes beyond traditional theory is in its consideration of the relevant actor inducing the standardization.

In particular, the relevant literature relaxes the assumption of contractual parties as unitary actors. It argues that that the provisions in the agreements are based on templates used by the drafting law firms. ${ }^{81}$ These law firms would generally be resistant to making changes to their templates, even if it were for the good of their client.82 The unwillingness to amend their templates would then lead to a particularly profound path dependence that could lock parties into suboptimal agreements for extended periods of time. ${ }^{83}$

79 See generally, e.g., Coates, supra note 31; GULATI \& ScOTT, supra note 28; Romano \& Sanga, supra note 30 . These authors are not the first to highlight the existence of seemingly suboptimal contractual terms. However, in contrast to the more recent contributions, scholars in the 1990s believed that suboptimality could generally be explained through the economics of networks and learning. In particular, see William A. Klein, C. David Anderson \& Kathleen G. McGuinness, The Call Provision of Corporate Bonds: A Standard Form in Need of Change, 18 J. CoRP. L. 653, 687, 696 (1993) (finding that a complex call provision capable of optimizing incentives and bond prices in corporate bond indentures is foregone in favor of a simpler rule that tends to overprice the embedded call option); Marcel Kahan, Anti-dilution Provisions in Convertible Securities, 2 STAN. J.L. Bus. \& Fin. 147, 159-60 (1995) (suggesting that antidilution provisions often employ boilerplate language that insufficiently protects holders of convertible securities who have the right to change their investment into a common stock); Kahan \& Klausner, supra note 33, at 750-51 (finding that event risk covenants in investment-grade bond indentures provide suboptimal compensation to bond holders in the event of takeovers).

80 See, e.g., Kahan \& Klausner, supra note 33, at 718-29 (discussing the benefits of boilerplate language to sophisticated actors).

81 Including not only traditional arm's-length contracts, but also bond indentures and corporate charters.

82 Coates, supra note 31, at 1303 ("[M]any [corporate lawyers] appear to be making choices, and mistakes, without determining whether such choices are in the long-term interests of their clients.").

83 See generally Choi et al., The Black Hole Problem, supra note 28. 
Several rationales have been proposed that may help explain this resistance. Some argue that increased economic pressure to commoditize legal services leads to standardization, and that it is economically infeasible to deviate from these templates. ${ }^{84}$ Others suggest that lawyers may be risk averse and afraid of the unknown scenarios that may unfold if the templates are tampered with, ultimately leading to a status quo bias. ${ }^{85}$ Yet others suggest that lawyers simply make routine cognitive errors and do not notice-or overlook-mistakes in their drafts. ${ }^{86}$ Sometimes, contract terms may also be "skeuomorphs" that lose their meaning over time, ${ }^{87}$ while continuously being used without much reflection-a phenomenon referred to as the "black hole problem." 88

What all of these explanations have in common is the conclusion that lawyers draft agreements that do not achieve an optimal allocation of the contractual surplus.

A few empirical studies have provided convincing evidence to support this hypothesis. ${ }^{89}$ However, currently, certain limitations prevent the stickiness literature from growing into an essential part of contract theory. First, the findings from previous studies are not necessarily generalizable. The majority of past inquiries focus on corporate charters and bylaws, ${ }^{90}$ as well as publicly

84 See Barak Richman, Contracts Meet Henry Ford, 40 HofSTRA L. REV. 77, 79 (2011) ("[I]f we apply [the literature on organizational economics] to the large law firm, we will conclude that the creation of mass-produced goods that do not ideally meet consumer demands should come as no surprise.").

85 See Peter B. Rutledge \& Christopher R. Drahozal, "Sticky" Arbitration Clauses? The Use of Arbitration Clauses After Concepcion and Amex, 67 VAND. L. REV. 955, 995 (2014) (contemplating the fear of unenforceability as a potential factor explaining the relative simplicity of arbitral agreements); Claire A. Hill, Why Contracts Are Written in "Legalese", 77 CHI.-KENT L. REV. 59, 79 (2001) (suggesting that lawyers might want to avoid learning how to navigate the language in an improved draft).

86 See Coates, supra note 31, at 1377-78; Hill, supra note 85, at 80 (suggesting that lawyers only ever catch a small subset of their errors if they become essential to the deal); Thomas J. Stipanowich, Contract and Conflict Management, 2001 WIS. L. REV. 831, 834 n.17 (describing that some law firms fail to adopt arbitration clauses because they equate arbitration with mediation).

87 See Douglas G. Baird, Pari Passu Clauses and the Skeuomorph Problem in Contract Law, 67 DUKE L.J. ONLINE 84, 97 (2017) (connecting the case of pari passu to the broader category of skeuomorphs).

88 See Choi et al., The Black Hole Problem, supra note 28, at 4 (quotation marks omitted).

89 See, e.g., Coates, supra note 31, at 1377-78; Choi et al., Dynamics of Contract Evolution, supra note 28, at 18-29 (conducting an empirical study of sovereign bond indentures and finding that external shocks as well as innovation by dominant law firms are required to effectuate change in templates).

90 See generally Coates, supra note 31; Romano \& Sanga, supra note 30. 
issued corporate ${ }^{91}$ and sovereign bonds. ${ }^{92}$ However, none of these documents is the result of a traditional bargaining process at arm's length that characterizes most commercial relationships. Charters and bylaws, though arguably susceptible to market incentives, are drafted by the corporation unilaterally. ${ }^{93}$ Similarly, though both bond issuers and holders can be large and sophisticated financial actors, the bond indentures for publicly issued bonds are rarely the result of a traditional bargaining process. Instead, bond issuers and underwriters cement the indentures, while bondholders do not participate directly. ${ }^{94}$ While underwriters have an incentive to create marketable bonds, they are also interested in preserving their relationship with the issuer, who wants to minimize constraints on the companies' or governments' future conduct. As such, bond indentures typically start with terms strongly favoring the issuer, and amendments are made in favor of bondholders only to the degree necessary to ensure marketability. ${ }^{95}$

Another aspect that makes bond indentures, specifically for corporate bonds, especially sticky-and conclusions drawn from their analysis difficult to generalize - is the existence of several model indentures that are widely used across the industry. The American Bar Association has published the ABF Model Debenture Indenture (1965), the ABA Model Simplified Indenture (1983, revised in 2000) and the Model Negotiated Covenants and Related Definitions (2006). It is believed that the model indentures

91 See generally Kahan, supra note 79; Kahan \& Klausner, supra note 33.

92 See generally GULATI \& SCOTT, supra note 28.

93 To be sure, there is disagreement on the amount of influence shareholder preferences have over the provisions in the corporate charter. See, e.g., Bernard S. Black, Is Corporate Law Trivial?: A Political and Economic Analysis, 84 Nw. U. L. REV. 542, 549-51 (1989) (summarizing different academic views). Amendments to the charter may be somewhat more directly influenced by other stakeholders. See James A. Brickley, Ronald C. Lease \& Clifford W. Smith, Jr., Corporate Voting: Evidence from Charter Amendment Proposals, 1 J. CORP. FIN. 5, 17-27 (1994) (finding evidence that shareholder involvement through voting on charter amendments is a moderately efficient disciplinary tool).

94 Metro. Life Ins. Co. v. RJR Nabisco, Inc., 716 F. Supp. 1504, 1509 (S.D.N.Y. 1989):

$[\mathrm{T}]$ he holders of public bond issues . . . often enter the market after the indentures have been negotiated and memorialized. Thus, those indentures are often not the product of face-to-face negotiations between the ultimate holders and the issuing company. ... [U]nderwriters ordinarily negotiate the terms of the indentures with the issuers.

95 Martin Riger, The Trust Indenture as Bargained Contract: The Persistence of Myth, 16 J. CORP. L. 211, 215-16 (1991) (describing how bond indentures are drafted). 
provide a widely used template across the industry, ${ }^{96}$ again increasing the probability for sticky covenants to evolve. In contrast, the vast majority of contracts does not evolve out of an industrywide model agreement, making results of the contracts under study here more representative and generalizable.

It should also be mentioned that studying bond indentures means studying one of "the most involved financial document[s] that has been devised." 97 The covenants that are the subject of previous studies typically deal with complex issues that require not only knowledge of the relevant legal rules, but also a significant level of expertise in the relevant financial market dynamics and incentive effects. ${ }^{98}$ The impenetrability of the underlying legal issues makes it especially likely for suboptimal rules favoring the issuer to emerge, given that most investors neither fully process, nor have an incentive to invest in identifying, how each covenant might affect their return or the default risk.

The lack of a traditional bargaining process, the existence of widely used templates, and the high degree of complexity raise questions as to whether the stickiness of contract provisions is an odd feature characterizing a small subset of particularly complex and standardized agreements, or whether law firm templates are an important determinant in explaining the resource allocation resulting from commercial contracts more generally.

This Article addresses many of these limitations by examining whether the stickiness hypothesis is able to explain the rarity of and variance in the use of dispute settlement provisions. By analyzing a broad range of corporate agreements across multiple issue areas, it provides a picture of how contracts are written outside of the area of bond issuances, allowing it to test whether rigidity is a characteristic of contract provisions more generally, or whether it is specific to certain issue areas. In addition, dispute resolution clauses lie at the core of legal expertise and touch upon an issue that is comparatively simple to comprehend and taught in every first-year law school curriculum. Hence, finding path

96 Ad Hoc Comm. for Revision of the 1983 Model Simplified Indenture, Revised Model Simplified Indenture, 55 BUS. LAW. 1115, 1115 (2000) (“The 1983 MSI and the 1983 Notes were promulgated with the hope that having a common form for the most standard provisions of indentures would reduce the need for significant negotiation of such provisions, and, in large part, the 1983 MSI accomplished that objective.").

97 Joseph C. Kennedy, Corporate Trust Administration AND Management 1 (1st ed. 1961).

98 Klein et al., supra note 79, at 657 (demonstrating the value of economic reasoning in the analysis of bond covenants). 
dependence in the prevalence of dispute resolution clauses makes for an especially compelling case of stickiness in contract drafting.

Another advantage of the study described in this Article is that the analysis of contractual gaps significantly reduces the number of potential explanations for observing stickiness. Previous studies focused on the wording of a covenant and how it relates to the presumed goal of the indenture, concluding that commercial actors are incapable of optimizing the wording of a clause. But choosing the optimum wording of contractual language is a choice from a space with virtually infinite alternatives. Trying to find the optimum choice among a great number of alternatives in such a setting quickly becomes economically infeasible, incentivizing actors to settle for contract terms that are good enough to achieve their goal without the need to optimize the text-a decisionmaking process also known as "satisficing."99 In contrast, this study focuses not on the optimal wording of the clause, but on its inclusion. The concept of satisficing is an unsuitable explanation for the existence of gaps, as parties should have clearly defined preferences on the inclusion or noninclusion of a clause.

Theoretical notions invoked by scholars in the 1990s to explain a suboptimal allocation of the contractual surplus are similarly unsuitable explanations for the existence of contractual gaps. For instance, it has previously been proposed that sticky drafting practices can be explained through the economics of networks and learning. ${ }^{100}$ By this account, because the benefits of standard clauses are often conferred only after they have been widely adopted in the future, companies are faced with a collective action problem that would cause them to choose a standard that is suboptimal from a social welfare perspective. ${ }^{101}$ Further, once a firm has accrued expertise and network benefits, switching would become prohibitively costly. ${ }^{102}$ Both of these rationales seem unlikely explanations for observing stickiness with respect to the omission of dispute settlement provisions. That is because parties who do not include such a clause can neither gradually improve upon it, nor can they feasibly be described as any

99 Patrick Bolton \& Antoine Faure-Grimaud, Satisficing Contracts, 77 REV. ECON. STUD. 937, 938 (2010).

100 Kahan \& Klausner, supra note 33, at 730-36.

101 Id. (describing how learning and network effects can lead to the adoption of suboptimal standards).

102 Id. at 727-29 (detailing the concept of "switching costs" that could prevent companies from changing to a more efficient standard). 
coherent network. Given that leaving the forum unspecified introduces uncertainty, a line of reasoning which postulates that a fear of the unknown and an extreme level of risk aversion may explain some of the drafters' behavior seems similarly ill-suited as an explanation. ${ }^{103}$ Thus, if it can be shown that stickiness characterizes the choice not to include a dispute resolution clause, this can be seen as compelling evidence in favor of one of the less discussed mechanisms, such as agency costs, cognitive errors, or another, yet undeveloped, theory.

\section{Hypotheses}

In this Article, I test the stickiness hypothesis in three steps. First, I examine whether the law firm is a relevant actor in the decision whether to include a dispute settlement provision. I investigate this question by considering the degree to which these clauses vary with external counsel, holding the parties to the agreement (and other observable characteristics) constant. To promote causal interpretability, I also exploit law firm closures as an external shock that forces both companies and drafters to change their law firm.

After establishing that the hiring decision of external counsel significantly influences not only whether or not parties have a dispute settlement provision in their agreement, but also which jurisdiction or arbitration organization they opt for, I examine the influence of the law firms' use of templates. In particular, I identify the law firm that proposed the first draft to an agreement, as well as the template the draft is based on. With this information in hand, I consider whether law firms bargain over the presence or absence of forum choice as found in the template.

Lastly, I consider whether law firms can be induced to make changes to their drafting practice in response to external shocks that change the costs and benefits of including the dispute resolution clause. To that end, I exploit the fact that a series of Supreme Court decisions significantly altered the default rules on forum choice and investigate whether these decisions changed the ways in which parties implemented forum selection clauses into their agreements. 


\section{DATA}

This Article uses the collection of all "material contracts" filed with the SEC through its Electronic Data Gathering, Analysis, and Retrieval system (EDGAR) between 2000 and 2016.104 The SEC requires registered companies to report every "material contract," which encompasses "every contract not made in the ordinary course of business that is material to the registrant." ${ }^{105}$ During the period of observation, a company had to register with the SEC if it had made a public offering or had "total assets exceeding $\$ 10,000,000$ and a class of equity security . . . held . . . by five hundred or more ... persons." 106

Companies attach the agreements to their annual reports (Form 10-K), quarterly reports (Form 10-Q), and to reports filed due to important events and changes between quarterly reports (Form 8-K). Similar provisions exist for foreign companies, which have the option to report using Forms $20-\mathrm{F}$ and 6-K. In addition, during mergers, the relevant contracts are reported as exhibits to Form S-4. I automatically collect all of these reported agreements for all registered companies through EDGAR. Overall, the data set includes 780,689 agreements between 2000 and 2016. From those, I drop 272,837 duplicates and amendments to existing contracts for a total of 507,852 unique contracts submitted by a total of 18,641 companies.

EDGAR includes data on the party that filed a contract and its industry. I assume the filing party to be the first party to the contract and its industry to be the industry pertaining to the contract. I then write a search algorithm that uses regular expressions to identify the paragraph in the contract that includes the parties to the dispute. The algorithm is described in detail in my other work. ${ }^{107}$ I scan this paragraph for the mention of any of the

104 A more detailed description of this data set and its creation is provided in Nyarko, supra note 14 , at $9-11$.

10517 C.F.R. $§ 229.601(b)(10)(i)$. "Material" in the disclosure context typically refers to information associated with "a substantial likelihood that a reasonable shareholder would consider it important" in making an investment decision. Basic Inc. v. Levinson, 485 U.S. 224, 231 (1988) (quotation marks omitted) (quoting TSC Indus., Inc. v. Northway, Inc., 426 U.S. 438, 449 (1976)). The SEC actively monitors compliance with this standard.

106 See Securities Acts Amendments of 1964, § 3(c), Pub. L. No. 88-467, 78 Stat. 565, 566-67 (1964) (amended 2012). Note that the regulations were amended on May 10, 2016, in order to implement Title V and Title VI of the Jumpstart Our Business Startups Act and Title LXXXV of the Fixing America's Surface Transportation Act. It now requires total assets exceeding $\$ 10,000,000$ and a class of equity security held by either 2,000 persons, or 500 persons who are not accredited investors. See 15 U.S.C. $§ 78 l(\mathrm{~g})(1)$.

107 Nyarko, supra note 14, at 9-13. 
630,106 companies and individuals that have ever disclosed information through filings with the SEC in order to supplement the information on the parties to the contract.

Next, it is necessary to identify whether a given agreement includes a dispute resolution clause and, if so, what type of dispute settlement provision the parties agreed on. Due to the large number of contracts, I train a machine learning algorithm that automatically identifies dispute resolution clauses. Separately, for clauses referring parties to courts and arbitration, training proceeds in these six steps:

(1) I split each contract into paragraphs and draw a random sample of 48,949 paragraphs.

(2) I manually inspect the sample, coding each paragraph as " 1 " if it contains a dispute settlement provision and " 0 " otherwise.

(3) I randomly divide the paragraphs into two sets, a "training set" ( $80 \%$ of the data) and a "test set" (20\% of the data).

(4) With the training set, I calibrate an algorithm ("classifier") 108 to identify terms and phrases that are most indicative of dispute resolution clauses, based on the preprocessed text in the paragraph. ${ }^{109}$

108 The algorithm is a Naive Bayes classifier. For a thorough examination of its properties, see Irina Rish, An Empirical Study of the Naive Bayes Classifier, in IJCAI 2001 WORKSHOP ON EMPIRICAL METHODS IN ARTIFICIAL INTELLIGENCE 41 (2001). While there are other popular options available, the Naive Bayes classifier yields the best results in many applications of text analysis. See, e.g., Harry Zhang, The Optimality of Naive Bayes, in

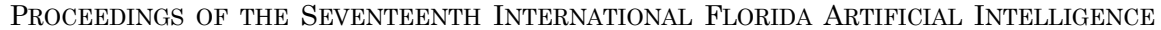
RESEARCH SOCIETY CONFERENCE 562, 563-65 (Valerie Barr \& Zdravko Markov eds., 2004) (discussing the "surprisingly good performance" of Naive Bayes classifiers).

109 The preprocessing steps include a conversion of all characters to lowercase; the removal of punctuation and special characters; the removal of stop words; and the removal of morphological affixes. The following example illustrates the effect of preprocessing on the text:

Before preprocessing

This is a forum selection clause between two companies that defines where disputes are litigated and whether jury trials are permitted. It serves as an example.

After preprocessing

forum select claus two compani defin disput litig whether juri trial permit serv exampl

The training uses a manually selected subset of terms and phrases, detailed in the appendix of Nyarko, supra note 14, at 19-23. 
(5) Using this trained classifier, I predict whether the provisions in the test set (which the classifier has not seen previously) are dispute resolution clauses or not.

(6) I compare the predictions generated from the trained algorithm to my hand coding in order to evaluate the performance of the classifier.

This approach correctly classifies $99.88 \%$ of the paragraphs. Overall, it can be considered as very accurate, with no strong tendency for false positives or negatives. ${ }^{110}$

I use a similar process to identify whether a contract includes a clause specifying the substantive law governing the contract and, if so, which law governs. In a last step, I use a combination of search terms and regular expressions to identify the type of the document (e.g., loan agreement, licensing contract) and the form of the document (e.g., agreement, plan, policy). The entire procedure is described in greater detail in my other work. ${ }^{111}$

In order to obtain data on a company's general counsel, I rely on FactSet. Though it is one of the most comprehensive data sets on general counsel, it has two important limitations. First, the data set contains information only on individuals who are currently active as general counsel. Hence, I do have information about a company's current general counsel and how long she worked for said firm, but I have no information on who the

110 The correct classification rate alone can sometimes be misleading, because it does not take into account the number of relevant items. For instance, for a test set consisting of 99 irrelevant paragraphs and 1 relevant paragraph, a simple algorithm that always considers all paragraphs irrelevant would achieve a correct classification rate of $99 \%$. This is why-in addition to the correct classification rate-studies in information retrieval and machine learning use precision, recall, $F_{1}$ scores, and Matthew's Correlation Coefficients (MCC) to assess the quality of automated classification procedures. For court selection clauses, the precision is 0.89 , the recall is 0.94 , and the $F_{1}$ score and Matthew's Correlation Coefficient are both 0.91 . The identification of arbitration clauses is even more reliable, with a precision of 0.99 , a recall of 1 , and an $F_{1}$ score and a Matthew's Correlation Coefficient of 1 . As a reference, in computer sciences, classifiers obtaining an $F_{1}$ score greater than 0.7 are considered sufficient for academic purposes. See, e.g., Wouter van Atteveldt, Jan Kleinnijenhuis, Nel Ruigrok \& Stefan Schlobach, Good News or Bad News? Conducting Sentiment Analysis on Dutch Text to Distinguish Between Positive and Negative Relations, 5 J. INFO. TECH. \& POL. 73, 83 (2008) (developing a system to conduct sentiment analysis that achieves an $F_{1}$ score of 0.63 , describing it as "[s]ignificantly better" than the baseline).

111 Nyarko, supra note 14, at 19-21. In contrast to my previous work, I have relabeled some ambiguous contract types. For instance, whereas my previous work identifies "Change in Control" agreements as M\&A agreements, I now consider them incentive contracts. This relabeling has no bearing on the substantive findings of the paper. 
general counsel was prior to the current counsel. ${ }^{112}$ Second, the general counsel information on FactSet is limited to companies publicly traded on large U.S. stock exchanges such as the New York Stock Exchange and NASDAQ. In total, the data set includes information on 4,201 general counsels for 4,670 companies drafting a total of 138,617 agreements. Because the SEC uses a company central index key (CIK) to identify companies, whereas FactSet uses the security identifiers CUSIP and ISIN, I rely on Compustat to translate CIKs to ISINs and merge the two data sets.

TABLE 1: SUMMARY STATISTICS

\begin{tabular}{|l|c|c|c|c|c|c|}
\hline & Mean & SD & Min & Max & Med & IQR \\
\hline Year & 2008 & 4.35 & 2000 & 2016 & 2008 & 7 \\
\hline $\begin{array}{l}\text { Dispute } \\
\text { Resolution } \\
\text { Clause }\end{array}$ & 0.44 & 0.50 & 0 & 1 & 0 & 1 \\
\hline $\begin{array}{l}\text { Forum } \\
\text { Selection } \\
\text { Clause }\end{array}$ & 0.30 & 0.46 & 0 & 1 & 0 & 1 \\
\hline $\begin{array}{l}\text { FSC } \\
\text { Length }\end{array}$ & 220 & 154 & 29 & 809 & 181 & 196 \\
\hline $\begin{array}{l}\text { Arbitration } \\
\text { Clause }\end{array}$ & 0.19 & 0.39 & 0 & 1 & 0 & 0 \\
\hline $\begin{array}{l}\text { Arb. } \\
\text { Clause }\end{array}$ & 324 & 245 & 27 & 1,128 & 255 & 313 \\
$\begin{array}{l}\text { Length } \\
\text { Choice of }\end{array}$ & 0.75 & 0.43 & 0 & 1 & 1 & 1 \\
$\begin{array}{l}\text { Law } \\
\text { Clause }\end{array}$ & & & & & & \\
\hline $\begin{array}{l}\text { CoL } \\
\text { Length }\end{array}$ & 79 & 77 & 16 & 401 & 47 & 66 \\
\hline $\begin{array}{l}\text { U.S.-U.S. } \\
\text { U.S.- }\end{array}$ & 0.89 & 0.31 & 0 & 1 & 1 & 0 \\
\hline $\begin{array}{l}\text { Foreign } \\
\text { Foreign- } \\
\text { Foreign }\end{array}$ & 0.01 & 0.09 & 0 & 1 & 0 & 0 \\
\hline
\end{tabular}

112 For example, if a company employed GC1 from 1999-2004, GC2 from 2004-2008 and GC3 from 2008-today, my data show that GC3 worked for the company since 2008, but I lack information on the general counsels prior to 2008, i.e., on GC1 and GC2. 
Table 1 contains summary statistics describing the contracts in the data set. ${ }^{113}$ Eighty-nine percent of contracts, the vast majority, are concluded exclusively between U.S. parties. Only 44\% of agreements in the period of observation include dispute resolution clauses, even though $75 \%$ include a clause specifying the substantive law of the contract. This may seem puzzling, given that both types of clauses seek to address issues arising out of uncertainties regarding the relevant and applicable legal framework. Among dispute resolution clauses, those that refer parties to courts are more prevalent than arbitration clauses $(30 \%$ versus $19 \%)$.

\section{FiguRE 1: DisPute Resolution Clauses OVER Time}

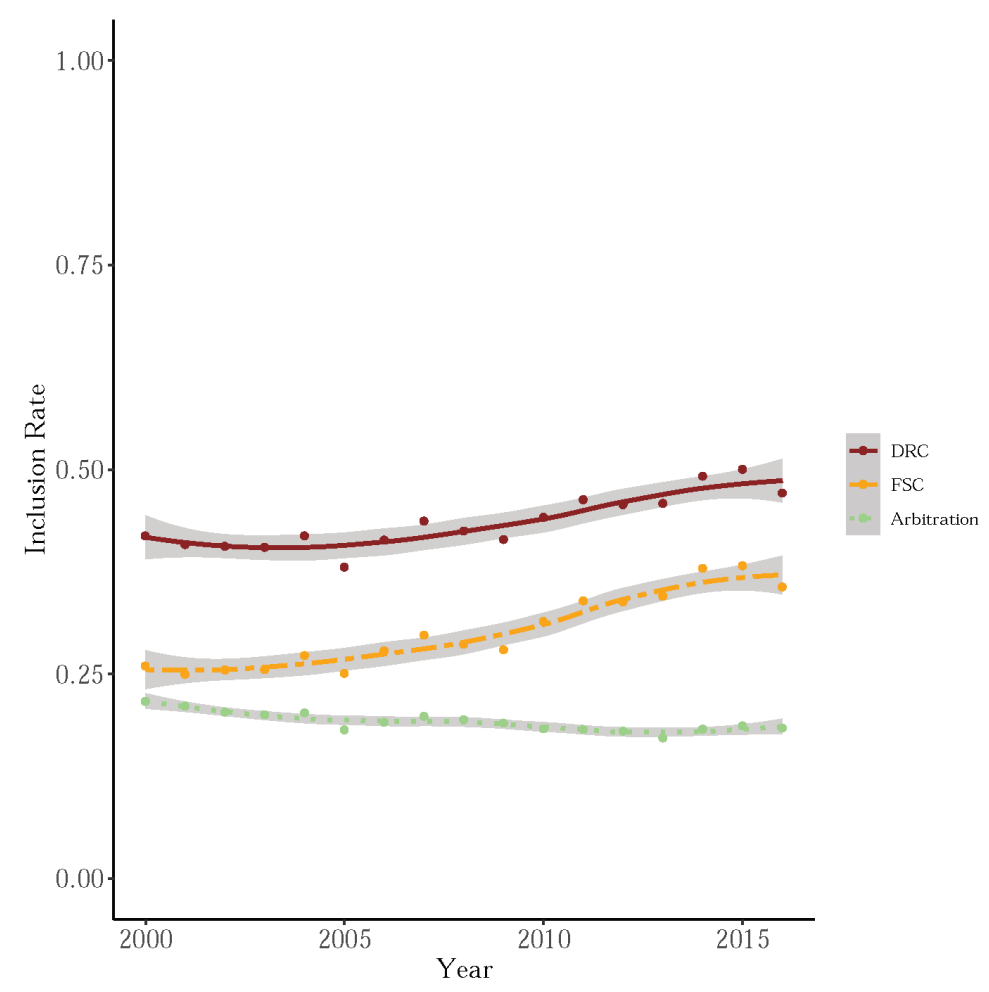

113 Column "Mean" reports the mean, "SD" the standard deviation, "Min" the minimum value, "Max" the maximum value, "Med" the median, and "IQR" the interquartile range, i.e., the difference between the 25 th and the 75 th percentile of the corresponding variable. 
Figure 1 plots the use of different types of dispute resolution clauses (DRC) over time. ${ }^{114}$ It shows that contracts became more likely to include dispute settlement provisions over the years. However, there is a difference between the propensity to include a forum selection clause (FSC)—referring parties to courts-and arbitration clauses. In particular, the higher propensity to include dispute resolution clauses is exclusively driven by the increased presence of clauses referring parties to courts. In contrast, arbitration clauses became less common over time. This finding contradicts some of the claims found in the literature contending that arbitration is becoming increasingly popular. ${ }^{115}$

Next, it is useful to examine the internal consistency of companies using dispute settlement provisions. If companies adopt firm-wide policies on the use of these clauses, we would expect many companies to consistently include them in their contracts. To examine whether this is the case, for each company in the data set, I collect all of its agreements and compute the average occurrence of dispute resolution clauses. The resulting number reflects how internally consistent companies are in their use of dispute settlement provisions. For instance, if company $i$ has an average rate of 0.95 , it means that $95 \%$ of agreements to which company $i$ is a party include dispute settlement provisions.

114 A locally estimated scatterplot smoothing (LOESS) regression is used to draw a smoothed line through the scatterplot.

115 For a detailed investigation with a focus on international agreements, see generally Nyarko, supra note 14 . 


\section{FigURE 2: INTERNAL COMPANY CONSISTENCY}

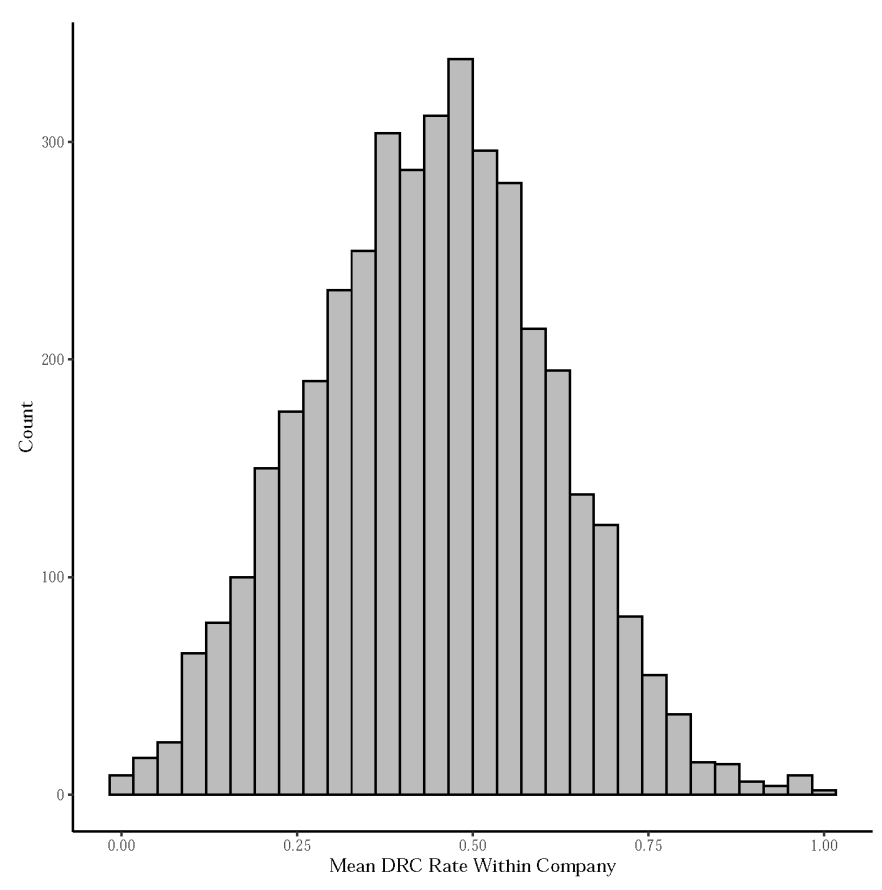

Figure 2 shows a histogram depicting where between 0 and 1 the mean usage rate lies for all companies in the data set. What can be seen is that the consistency measure is almost normally distributed around 0.5. This indicates that most companies sometimes use dispute settlement provisions while at other times omitting them. There are only very few companies that consistently include dispute resolution clauses, which is indicated by the fact that almost no company has a mean usage rate that is anywhere close to 1 . Overall, the data suggest that the vast majority of companies lacks a coherent and widely enforced policy on the inclusion of dispute settlement provisions. 
TABLE 2: DisPUTE RESOLUTION ClAUSES BY INDUSTRY

\begin{tabular}{|l|c|c|c|c|c|c|}
\hline \multicolumn{1}{|c}{ Industry } & Obs. & Freq. & FSC & Arb. & DRC & CoL \\
\hline Agriculture & 13 & 0.00 & 0.23 & 0.38 & 0.54 & 0.85 \\
\hline Services & 99,596 & 0.20 & 0.32 & 0.21 & 0.46 & 0.75 \\
Other & 9,360 & 0.02 & 0.33 & 0.18 & 0.46 & 0.83 \\
\hline Mining & 31,451 & 0.06 & 0.32 & 0.18 & 0.44 & 0.77 \\
\hline Transportation & 45,472 & 0.09 & 0.31 & 0.18 & 0.43 & 0.74 \\
\hline Manufacturing & 175,413 & 0.35 & 0.30 & 0.19 & 0.43 & 0.73 \\
\hline Trade & 40,671 & 0.08 & 0.30 & 0.18 & 0.43 & 0.75 \\
\hline Finance & 100,608 & 0.20 & 0.28 & 0.19 & 0.42 & 0.77 \\
\hline Construction & 5,268 & 0.01 & 0.30 & 0.15 & 0.41 & 0.74 \\
\hline
\end{tabular}

Table 2 breaks down the prevalence of dispute resolution clauses by industry. ${ }^{116}$ Most of the contracts in the sample come from the manufacturing industry, followed by the finance industry and the service industry. What can be seen is that the agricultural industry is the only industry where dispute resolution clauses are more likely to be included than not included. However, with only thirteen observations, these numbers are not particularly reliable. In all other industries, fewer than half of the contracts analyzed contained a dispute settlement provision (between $41 \%$ and $46 \%$ ), even though one is very likely to find a governing law clause in contracts across all industries (between 73\% and 85\%). Throughout all industries, arbitration clauses are relatively rare, with choice-of-forum clauses dominating the landscape of dispute settlement provisions.

116 Column "Obs." indicates the number of observations in the data set, "Freq." the relative frequency, "FSC" the fraction of contracts with forum selection clauses referring parties to a court jurisdiction, "Arb." the fraction of contracts that include an arbitration clause, "DRC" the overall fraction of contracts including any dispute resolution clause (arbitration or courts), and "CoL" the fraction of contracts including a choice-of-law provision. 
TABle 3: Dispute Resolution Clauses By AgReement TyPe

\begin{tabular}{|l|c|c|c|c|c|c|}
\hline \multicolumn{1}{|c}{ Type } & Obs. & Freq. & FSC & Arb. & DRC & CoL \\
\hline M\&A & 62,839 & 0.12 & 0.53 & 0.23 & 0.64 & 0.89 \\
\hline Joint Venture & 1,399 & 0.00 & 0.26 & 0.44 & 0.61 & 0.74 \\
\hline Licensing & 9,431 & 0.02 & 0.32 & 0.39 & 0.61 & 0.80 \\
\hline Loan & 57,086 & 0.11 & 0.53 & 0.10 & 0.58 & 0.80 \\
\hline Sales & 15,898 & 0.03 & 0.37 & 0.21 & 0.50 & 0.78 \\
\hline Security & 21,084 & 0.04 & 0.44 & 0.09 & 0.49 & 0.82 \\
\hline Employment & 108,313 & 0.21 & 0.23 & 0.33 & 0.49 & 0.75 \\
\hline Consulting & 7,860 & 0.02 & 0.25 & 0.28 & 0.48 & 0.78 \\
Other & 42,391 & 0.08 & 0.37 & 0.15 & 0.47 & 0.81 \\
\hline Transportation & 1,313 & 0.00 & 0.30 & 0.24 & 0.47 & 0.70 \\
\hline Lease & 16,076 & 0.03 & 0.21 & 0.27 & 0.40 & 0.66 \\
\hline Negotiable & 14,024 & 0.03 & 0.36 & 0.05 & 0.39 & 0.81 \\
Instrument & & & & & & \\
\hline Legal & 10,002 & 0.02 & 0.30 & 0.11 & 0.38 & 0.71 \\
\hline Incentives & 140,136 & 0.28 & 0.12 & 0.11 & 0.21 & 0.64 \\
\hline
\end{tabular}

Breaking contracts down by agreement type, as in Table 3, paints a somewhat different picture. M\&A, joint venture, licensing, loan, and sales agreements are more likely than not to include a dispute resolution clause. At the same time, contracts providing incentives to key employees, such as employee stock option plans, pension plans, and "golden parachute" agreements are the least likely to include a dispute resolution clause. While caution is advised when interpreting descriptive statistics, these findings are at least consistent with the idea that contracts of great economic importance are more likely to be carefully drafted by parties making a greater effort to anticipate contingencies.

The descriptive statistics are also consistent with isolated findings in the literature on the relevance of dispute settlement clauses in specific settings. For instance, it has previously been argued that contracts over innovative goods-among them, joint venture and licensing agreements - are particularly sensitive to the issue of legal enforcement due to a high level of dependence on injunctive and emergency relief. ${ }^{117}$ For M\&A, it has been

117 See Erin O'Hara O'Connor \& Christopher R. Drahozal, The Essential Role of Courts for Supporting Innovation, 92 TEX. L. REv. 2177, 2182-83 (2014) (“[P]arties evidently perceive courts as having a relative advantage in providing injunctive relief. ... In addition, courts are better suited to providing the emergency relief that may be necessary to prevent serious harm to parties' intellectual property rights."). 
argued that the close entanglement of contract law with corporate, securities, and antitrust law provides incentives for parties to pay especially close attention to harmonizing the legal framework surrounding their deal. In effect, this often means that forum selection clauses refer disputes to Delaware. ${ }^{118}$

TABLE 4: MOST POPULAR COURT FORUMS

\begin{tabular}{|l|c|c|c|}
\hline \multicolumn{1}{|c|}{ Forum } & Mean FSC & Mean CoL & Overlap \\
\hline New York & 0.37 & 0.26 & 0.91 \\
\hline Delaware & 0.11 & 0.15 & 0.89 \\
\hline California & 0.08 & 0.09 & 0.87 \\
\hline Texas & 0.05 & 0.05 & 0.89 \\
\hline Florida & 0.03 & 0.03 & 0.91 \\
\hline Illinois & 0.03 & 0.02 & 0.89 \\
\hline Nevada & 0.02 & 0.02 & 0.92 \\
\hline New Jersey & 0.02 & 0.02 & 0.94 \\
\hline Massachusetts & 0.02 & 0.02 & 0.92 \\
\hline Pennsylvania & 0.02 & 0.02 & 0.86 \\
\hline Ohio & 0.01 & 0.02 & 0.89 \\
\hline Colorado & 0.01 & 0.01 & 0.88 \\
\hline Minnesota & 0.01 & 0.01 & 0.84 \\
\hline Georgia & 0.01 & 0.02 & 0.91 \\
\hline Virginia & 0.01 & 0.01 & 0.80 \\
\hline
\end{tabular}

Next, Table 4 depicts how frequently different court forums are chosen.119 Consistent with previous findings in the literature, ${ }^{120}$ New York is by far the most popular forum, with $37 \%$ of forum selection clauses referring parties to New York courts. It is commonly assumed that the reason for this dominance is the high level of expertise New York courts have in adjudicating complex

118 See Cain \& Davidoff, supra note 70, at 98; John C. Coates IV, Managing Disputes Through Contract: Evidence from M\&A, 2 HARV. Bus. L. REV. 295, 335 (2012).

119 Column "Mean FSC" indicates the share of contracts that refer to the courts in the corresponding jurisdiction among all contracts with choice-of-forum provisions. "Mean CoL" indicates the fraction of contracts applying the substantive law of the corresponding jurisdiction through a choice-of-law provision. Column "Overlap" considers only contracts with both a choice-of-law and a forum selection clause. It indicates how likely it is that a contract with a forum selection clause opting into the corresponding jurisdiction also chooses the same substantive law.

120 See Theodore Eisenberg \& Geoffrey P. Miller, The Flight to New York: An Empirical Study of Choice of Law and Choice of Forum Clauses in Publicly-Held Companies' Contracts, 30 CARDOZO L. REV. 1475, 1504 (2009). 
commercial disputes. ${ }^{121}$ In addition, most large law firms are headquartered in New York, and economies of scale incentivize attorneys interested in practicing business law to seek admission to the New York bar, making it an unsurprising primary choice for dispute settlement. Other popular forums include Delaware (11\%), California (8\%), and Texas (5\%).

If a contract includes both a choice-of-forum and a choice-oflaw clause, parties consistently match the substantive law to the forum. This finding confirms interviews conducted by Professors Matthew Cain and Steven Davidoff in which lawyers stated that their primary concern in drafting these clauses is to avoid an incoherence between the law governing the contract and the forum that interprets it. ${ }^{122}$

Consider now the question of which law firm assisted in drafting a contract. While contracts often do not name a law firm responsible for drafting the agreement, there are many instances in which they do. Typically, the drafting law firm is disclosed in the notice clause, which requires a copy of any written communication relating to the contract to be submitted to the counsel that assisted in drafting the agreement. Other instances in which law firms appear include fee shifting clauses-when one party agrees to pay for the administrative costs of the other's counsel-or clauses stating where the contract will be signed, which is often in one of the advising law firm's offices. I exploit this fact using a list of 7,708 law firms with at least 50 employees, collected through LexisNexis Academic, to identify the external counsel involved in the drafting of an agreement. This approach successfully identifies participating law firms for 105,746 contracts. It is important to note that this is not a random sample of all contracts. Contracts identifiably drafted by law firms tend to be longer and more likely to include dispute settlement provisions and choice-of-law clauses than the average contract. ${ }^{123}$

121 See Mitchell L. Bach \& Lee Applebaum, A History of the Creation and Jurisdiction of Business Courts in the Last Decade, 60 Bus. LAW. 147, 158 (2004) (discussing the success of the Commercial Division within New York court system).

122 Cain \& Davidoff, supra note 70, at 98.

123 The average contract length is 9,207 words; if a law firm drafted the contract, 23,328 words. $44 \%$ of contracts include a dispute resolution clause, $74 \%$ if a law firm is involved. $75 \%$ of contracts include a dispute resolution clause, $94 \%$ if a law firm is involved. 
TABLE 5: Most FREQUENT DRAFTERS

\begin{tabular}{|c|c|c|c|c|c|}
\hline Law Firm & \# Contracts & FSC & Arbitration & DRC & $\mathrm{CoL}$ \\
\hline $\begin{array}{l}\text { Latham \& } \\
\text { Watkins, LLP }\end{array}$ & 4,995 & 0.65 & 0.25 & 0.76 & 0.97 \\
\hline $\begin{array}{l}\text { Skadden, Arps, } \\
\text { Slate, Meagher } \\
\text { \& Flom LLP }\end{array}$ & 4,833 & 0.69 & 0.27 & 0.82 & 0.97 \\
\hline $\begin{array}{l}\text { Kirkland \& Ellis } \\
\text { LLP }\end{array}$ & 3,362 & 0.64 & 0.22 & 0.73 & 0.97 \\
\hline $\begin{array}{l}\text { Simpson } \\
\text { Thatcher \& } \\
\text { Bartlett LLP }\end{array}$ & 3,232 & 0.71 & 0.21 & 0.81 & 0.97 \\
\hline $\begin{array}{l}\text { Greenburg } \\
\text { Traurig LLP }\end{array}$ & 2,625 & 0.68 & 0.20 & 0.77 & 0.95 \\
\hline $\begin{array}{l}\text { Weil, Gotshal \& } \\
\text { Manges LLP }\end{array}$ & 2,310 & 0.73 & 0.21 & 0.81 & 0.96 \\
\hline $\begin{array}{l}\text { Shearman \& } \\
\text { Sterling LLP }\end{array}$ & 2,118 & 0.65 & 0.15 & 0.72 & 0.98 \\
\hline $\begin{array}{l}\text { Vinson \& Elkins } \\
\text { LLP }\end{array}$ & 2,084 & 0.66 & 0.23 & 0.76 & 0.97 \\
\hline Jones Day & 2,044 & 0.74 & 0.24 & 0.82 & 0.94 \\
\hline $\begin{array}{l}\text { Wilson Sonsini } \\
\text { Goodrich \& } \\
\text { Rosati }\end{array}$ & 2,008 & 0.68 & 0.31 & 0.79 & 0.96 \\
\hline $\begin{array}{l}\text { Wachtell, Lipton, } \\
\text { Rosen \& Katz }\end{array}$ & 1,868 & 0.74 & 0.21 & 0.83 & 0.96 \\
\hline $\begin{array}{l}\text { DLA Piper LLP } \\
\text { (US) }\end{array}$ & 1,819 & 0.70 & 0.27 & 0.82 & 0.95 \\
\hline $\begin{array}{l}\text { Davis Polk \& } \\
\text { Wardwell LLP }\end{array}$ & 1,813 & 0.78 & 0.14 & 0.81 & 0.97 \\
\hline $\begin{array}{l}\text { Sidley Austin } \\
\text { LLP }\end{array}$ & 1,798 & 0.73 & 0.23 & 0.79 & 0.97 \\
\hline $\begin{array}{l}\text { Morgan, Lewis } \\
\& \text { Bockius LLP }\end{array}$ & 1,775 & 0.64 & 0.28 & 0.74 & 0.96 \\
\hline Mayer Brown & 1,771 & 0.68 & 0.17 & 0.74 & 0.95 \\
\hline $\begin{array}{l}\text { Gibson, Dunn \& } \\
\text { Crutcher LLP }\end{array}$ & 1,764 & 0.67 & 0.26 & 0.78 & 0.97 \\
\hline $\begin{array}{l}\text { Cravath, Swaine } \\
\& \text { Moore LLP }\end{array}$ & 1,698 & 0.82 & 0.14 & 0.85 & 0.97 \\
\hline $\begin{array}{l}\text { Ropes \& Gray } \\
\text { LLP }\end{array}$ & 1,694 & 0.64 & 0.19 & 0.72 & 0.96 \\
\hline
\end{tabular}




\begin{tabular}{|l|c|c|c|c|c|}
\hline \multicolumn{1}{|c|}{ Law Firm } & \# Contracts & FSC & Arbitration & DRC & CoL \\
\hline $\begin{array}{l}\text { Cahill Gordon \& } \\
\text { Reindel LLP }\end{array}$ & 1,657 & 0.72 & 0.07 & 0.74 & 0.98 \\
$\begin{array}{l}\text { Akin Gump } \\
\text { Strauss Hauer } \\
\text { \& Feld LLP }\end{array}$ & 1,596 & 0.65 & 0.26 & 0.77 & 0.96 \\
$\begin{array}{l}\text { Sichenzia Ross } \\
\text { Friedman }\end{array}$ & 1,580 & 0.74 & 0.16 & 0.82 & 0.96 \\
$\begin{array}{l}\text { Ference LLP } \\
\text { O'Melveny \& } \\
\text { Myers LLP }\end{array}$ & 1,506 & 0.60 & 0.30 & 0.77 & 0.96 \\
$\begin{array}{l}\text { Paul Hastings } \\
\text { LLP }\end{array}$ & 1,501 & 0.70 & 0.28 & 0.81 & 0.95 \\
$\begin{array}{l}\text { Morrison \& } \\
\text { Foerster LLP } \\
\text { Sullivan \& } \\
\text { Cromwell LLP }\end{array}$ & 1,453 & 0.68 & 0.26 & 0.79 & 0.96 \\
$\begin{array}{l}\text { White \& Case } \\
\text { LLP }\end{array}$ & 1,414 & 0.73 & 0.21 & 0.82 & 0.96 \\
\hline $\begin{array}{l}\text { Goodwin } \\
\text { Proctor LLP }\end{array}$ & 1,351 & 0.69 & 0.29 & 0.80 & 0.96 \\
$\begin{array}{l}\text { Bingham } \\
\text { McCutchen LLP }\end{array}$ & 1,302 & 0.66 & 0.21 & 0.75 & 0.95 \\
$\begin{array}{l}\text { Paul, Weiss, } \\
\text { Rifkind, } \\
\text { Wharton \& } \\
\text { Garrison LLP }\end{array}$ & 1,295 & 0.74 & 0.21 & 0.82 & 0.97 \\
\hline
\end{tabular}

Table 5 depicts the thirty most frequently relied upon law firms. By far the most contracts are drafted by Latham \& Watkins and Skadden, Arps, Slate, Meagher \& Flom LLP, with 4,995 and 4,833 contracts, respectively. Choice-of-law clauses are almost universally adopted, with most law firms including them in over 96\% of their contracts. Dispute resolution clauses are less common, with most law firms including them in $70-80 \%$ of contracts. ${ }^{124}$ One notion, consistent with the finding that both choiceof-law and dispute settlement provisions are more likely in

124 These numbers are somewhat consistent with an analysis of M\&A contracts by Cain and Davidoff, who found that choice-of-law provisions are universally adopted, but choice-of-forum provisions are included in only $86.5 \%$ of contracts. Cain \& Davidoff, supra note 70, at 106 ("With respect to choice of forum clauses, 13.5 percent of agreements select no forum at all."). 
contracts in which the drafting firm can be identified, is that the supervision of external counsel decreases, but does not reduce to zero, the probability for a contractual gap. Another theory consistent with this finding is that lawyers are used in more complex transactions, and that in complex transactions, all participants are more mindful of the issue of forum choice.

Lastly, I identify the particular counsel responsible for drafting the agreement. Similar to the identity of the drafting law firm, notice clauses typically specify the individuals the notices should be addressed to. I parse the notice clauses from the contracts using regular expressions and then perform a task known as "Named Entity Recognition" to extract personal names from the notice clauses. ${ }^{125}$ Overall, this process identifies 53,952 names in 73,701 contracts.

To summarize, for each material contract, the data set includes (1) information on contract characteristics, such as the type of the contract, its length and the year it has been filed; (2) information on the drafting parties, such as their Central Index Key, their industry, and their place of incorporation; (3) information on the choice-of-law and dispute settlement provisions in the contracts, including whether and where the parties opt for litigation and arbitration; and (4) the identity of the lawyers and law firms that assisted in drafting the agreement, if available.

\section{LAW FIRM INFLUENCE}

Having thus compiled the data set, I proceed with the first test, examining if and to what extent the decision to include, or not to include, a dispute settlement provision is influenced by external counsel.

Figure 2 above shows that companies seem to lack firm-wide policies on dispute resolution clauses. Instead, most firms

125 To perform the task, I rely on the Stanford Named Entity Recognizer, offered by The Stanford Natural Language Processing Group. The Named Entity Recognizer uses a combination of seven class models for tagging locations, personal names, organizations and others. See generally Jenny Rose Finkel, Trond Grenager \& Christopher Manning, Incorporating Non-Local Information into Information Extraction Systems by Gibbs Sampling, in ProceEdings of the 43RD ANNUAL MeEting of the Association for Computational Linguistics 363 (Kevin Knight et al. eds, 2005); see also Named Entity Recognizer, Stan. NAT. LANGUAGe PROCESSING GRP., https://perma.cc/UV4D-S3QW. I supplement the algorithm with a set of rules to guarantee that street and law firm names are omitted. In order to guarantee that I only include the names of external counsel, I additionally require the name to appear shortly after the name of the law firm. Effectively, this excludes the names of internal counsel from the process. 
sometimes include, and sometimes do not include, these provisions. Because the identity of the company does not seem to induce consistency, it seems theoretically plausible that external counsel has ample room to determine independently whether a contract should specify the dispute settlement mechanism.

\section{A. Main Analysis}

In deriving a test that investigates law firm influence on the presence of dispute resolution clauses, consider the following analytical approach: Assume we have four similar contracts, $A, B$, $C$, and $D$. Contracts $A$ and $B$ are drafted by the same law firm, whereas contracts $C$ and $D$ are drafted by different law firms. Then we can assess the influence of the actors on dispute resolution provisions with the following three-step process: ${ }^{126}$

(1) Compute the difference in dispute resolution clause usage between contracts $A$ and $B$.

(2) Compute the difference in dispute resolution clause usage between contracts $C$ and $D$.

(3) Compare the quantity computed under (1) to the quantity computed under (2).

If law firms have an influence on whether a contract includes a dispute settlement provision, then, in the aggregate, the probability that two contracts both include the same dispute resolution clause should be high when the law firms are the same (quantity under step one) and smaller when the law firms are different (quantity under step two). ${ }^{127}$ A similar rationale applies to inhouse counsel, allowing one to compare the influence of internal legal advisers to that of the law firms.

The main challenge in implementing this procedure is to guarantee that contracts $A, B, C$, and $D$ are, in fact, similar. This is no easy feat. Indeed, contracts in the data set differ in a variety of ways, such as in the companies that are party to the agreement, the industry, or the contract type. If left unaddressed, it is at least possible that the difference between two contracts is caused by factors other than the law firm.

126 The setup follows the same logic as a difference-in-difference design. In essence, it compares the difference of contracts under the same law firm to the difference of contracts under different law firms.

127 In absolute terms. 
In order to ameliorate concerns arising out of this form of omitted variable bias, I employ matching to create pairs of company contracts. Matching is a popular method in the social sciences and causal inference that seeks to pair two units that look similar on a number of dimensions, with the only observable difference being the variable of interest.128 Among the different matching algorithms, exact matching is the most restrictive, as it requires each pair of observations to be exactly the same across all characteristics. This has advantages and disadvantages. The main disadvantage is that an exact-matching algorithm omits a lot of data, as pairs that are even slightly dissimilar are removed. However, in very large data sets such as this one, omitting data is not a primary concern as long as reliable standard errors can be obtained. The main advantage of exact matching is that it is able to achieve perfect homogeneity across all observed characteristics, making both contracts highly comparable on these observed dimensions.

Having created matched pairs of similar contracts in this way, I use OLS regression to investigate the average law firm influence on the presence of dispute resolution clauses. ${ }^{129} \mathrm{I}$ then do the same for general counsel influence. The results are presented in Figure 3.130 Each row in the plot corresponds to a different model and contains two dots. The red dots indicate a lower bound on the law firm's influence on dispute settlement provisions in the contract. ${ }^{131}$ For instance, a dot at 0.1 suggests that a change in law firms is associated with at least a ten percentage point increase in the probability to encounter one contract with and one without a dispute settlement provision. The blue dot depicts the lower bound on the influence of the general counsel.

The red and blue lines depict 95\% confidence intervals and can be thought of as a certainty measure. If the confidence intervals include the dotted line at zero, this suggests that that law

128 The estimates derived from these pairs decrease potential omitted variable bias and guarantee common support. See Donald B. Rubin, Matching to Remove Bias in Observational Studies, 29 BIOMETRICS 159, 170-76 (1973).

129 Employment and incentive contracts, as well as those in which only one party can be identified, are omitted. That is because it cannot be guaranteed that the parties are identical across dyads.

130 For numeric regression tables, see infra Part A.II.

131 It is an estimate that makes conservative assumptions about the between-lawfirm consistency and thus yields a lower bound. For details on estimating the upper bound, see generally Joshua B. Fischman, Measuring Inconsistency, Indeterminacy, and Error in Adjudication, 16 AM. L. \& ECON. REV. 40 (2014). 
firms or general counsel may have no impact on the prevalence of dispute settlement provisions. If it does not include zero, by conventional measures, the influence is statistically significant. ${ }^{132}$

\section{FIGURE 3: LAW FIRM AND GENERAL COUNSEL INFLUENCE ON DISPUTE RESOLUTION CLAUSES}

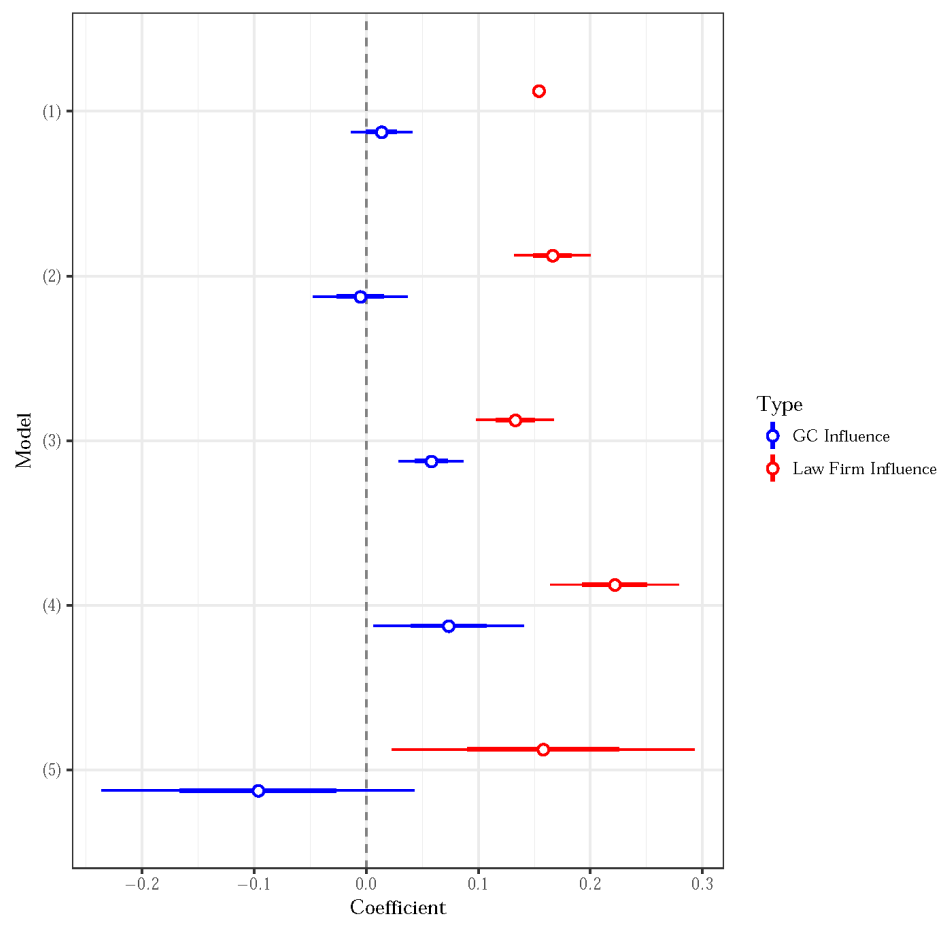

Model (1) only matches on parties and provides a baseline. Model (2) only includes contract pairs where-in addition to the parties - the format, type, and industry of the agreements in the pair are identical, i.e., matched pairs. It further controls for the contract type, format, and industry through the inclusion of fixed effects. ${ }^{133}$ It also controls for the difference in years in which the contracts were reported. The resulting analysis guarantees that contracts are highly comparable on the observed dimensions.

132 In statistical jargon, the null hypothesis of no law firm influence cannot be rejected if the confidence interval includes zero. Else it can be rejected by convention.

133 The reference category for categorical variables are the most frequent categories (i.e., statistical modes). The reference format is "agreement," the reference contract type is "M\&A," and the reference industry is "Manufacturing." 
Model (3) adds party-pair fixed effects to control for unobserved, party-pair specific characteristics.

The results are striking. The probability for two contracts to differ is between thirteen and twenty-three percentage points if both agreements were drafted by the same law firm. ${ }^{134}$ If law firms change, depending on the model specification, the probability increases by fifteen to twenty-three percentage points. In relative terms, this is an increase of about $100 \%$. Meanwhile, most specifications suggest that the general counsel has no discernable influence on whether a contract includes a dispute resolution clause. And even when the coefficient is statistically significant, it is small, with a difference of six percentage points.

Model (4) investigates the law firm and general counsel influence not on the presence of a choice-of-forum provision, but on the specific jurisdiction parties specify in their clause. ${ }^{135}$ Model (5) analyzes the influence on the particular arbitral institution that parties opt for. Both models yield generally consistent results with the other specifications.

\section{B. Identification Through Law Firm Closure}

The preceding analysis suggests that law firms have a large influence on the presence of dispute resolution provisions, whereas there is no consistent evidence that the general counsel is a significant actor. However, we need to exert caution in interpreting these estimates causally. For one, while matching guarantees that the contracts in each pair look identical on all observed characteristics, it is possible that unobserved characteristics, such as the transactional value, still govern which law firm is hired, as well as whether a dispute resolution clause is included. Hence, the presence of omitted variable bias cannot be ruled out with certainty.

In addition, there is at least the possibility that the causal effect runs in the opposite direction. Companies may choose to hire a certain law firm based on considerations that correlate with the use of dispute settlement provisions. For instance, it is possible that certain law firms have developed a particular expertise in drafting deals involving companies incorporated in Delaware, whereas others are more proficient in transactions involving California companies. If the place of incorporation affects the

134 Obtained from the constant in the baseline OLS regression. See infra Part A.II.

135 Provided that a dispute settlement provision is present. 
incentives to include dispute resolution clauses, then it may be the case that any difference associated with the law firm really is a reflection of company preferences, mediated through the choice of external counsel.

In order to further address these possible shortcomings, I supplement the results with an analysis that allows me to assess whether companies strategically choose their counsel for reasons that are correlated with the use of dispute settlement provisions. Following an identification strategy introduced by Professor Adam Badawi, ${ }^{136}$ I make use of the fact that some law firms collapsed during the period of observation. A law firm collapse forces companies to hire new external counsel for reasons that are uncorrelated with both company and drafting preferences. ${ }^{137}$ I exploit this external shock in two ways.

First, if companies self-select into law firms with particular drafting practices or exert control over how law firms draft the provisions, then a change of law firms after a collapse should have no impact on the drafts, because the law firm change was nonstrategic and the affected company will hire a law firm with similar practices to the previous one.

To examine this claim, I identify in the data set those pairs in which the first contract was drafted by a collapsed law firm and the second contract was drafted by a different firm. These are the contract pairs in which the client can reasonably be assumed to have had no choice but to change law firms due to the collapse. I compare these to contract pairs in which a change of law firms did not occur. If it is true that clients generally self-select into firms based on their template, then we would expect a collapseinduced change of law firms to be no different than no change of law firms at all. ${ }^{138}$

Second, among the partners who move from collapsing law firms to new law firms, those who change their drafting practices should be less likely to retain clients than those partners who continue the practices of their previous firm. ${ }^{139}$

136 Badawi, supra note 32, at 17-18 (exploiting variation induced by law firm collapses to examine variation in the language of registration statements).

137 See John Morley, Why Law Firms Collapse, 75 BUs. LAW. 1399, 1431-33 (2020) (detailing that most law firm collapses happen suddenly and unexpectedly as a consequence of the equivalent of a "bank run" among partners).

138 The models include an interaction term, as the identification assumption is more likely to be satisfied for observations close to the year of collapse.

139 One might contend that causality runs in the opposite direction. That is, partners who are not going to retain their clients may be more willing to adopt the new law firm's 
In order to assess the validity of this claim, I first create a list of lawyers who have worked at one of the collapsed firms and who have drafted at least five contracts prior to and after their firm's collapse. I then do a manual web search for each of these names in order to (i) verify that these lawyers have indeed worked at the collapsed firm; and (ii) determine what firm they have moved to after the collapse. This process provides me with names and the employment history of a total of forty-nine partners working at one of the collapsed law firms. ${ }^{140}$

Next, for each of these partners, I create contract pairs. Each pair includes one contract drafted before and one contract drafted after the collapse. I then look at (i) whether both contracts have the same dispute settlement provision; and (ii) whether both contracts were written for the same client. If clients are more likely to stay with their partners if the partner sticks to previous drafting practices, then we would expect a negative relationship between a change in drafting practices and the client retention rate.

\section{FIGURE 4: USING LAW FIRM COLLAPSE AS IDENTIFICATION}

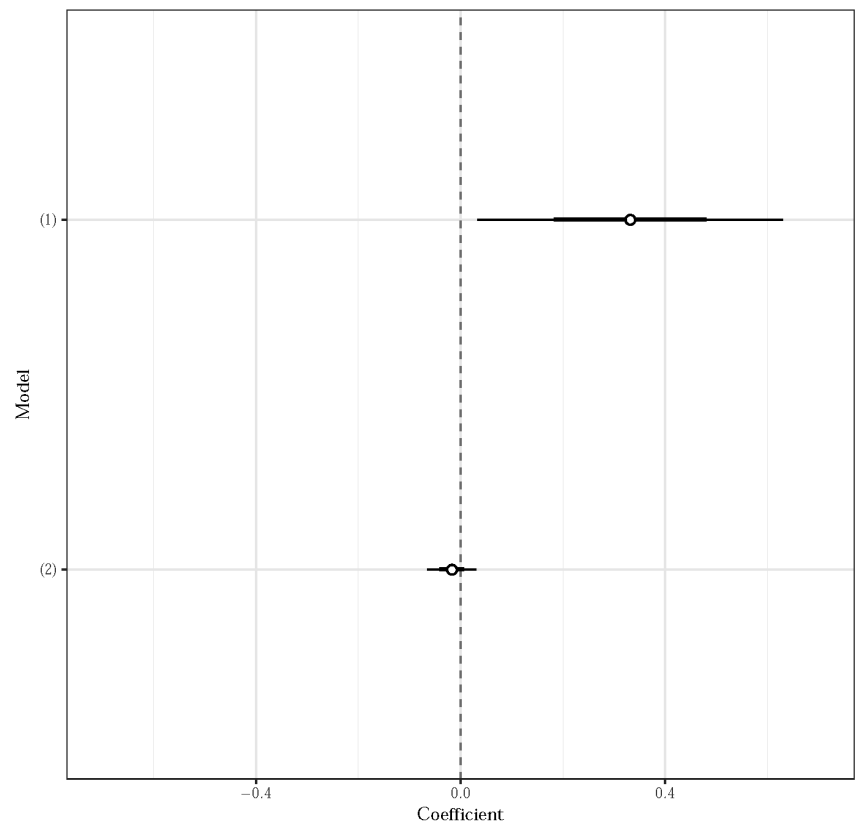

draft. However, if this relationship exists, it should bias the results upwards, i.e., it should be even easier to detect a significant relationship.

140 Only one name in the data set is associated with a senior associate, rather than a partner. 
Figure 4 presents the results. As can be seen, the collapseinduced law firm change has a significant influence on whether contracts include dispute settlement provisions (Model (1)). ${ }^{141}$ At the same time, whether a lawyer changes her template has no relevant impact on whether she retains her clients (Model (2)). ${ }^{142}$ Both of these findings indicate that companies do not strategically select their law firms in a way that would correlate with the prevalence of dispute settlement provisions. To sum up, the results of the analysis suggest that the presence and type of dispute resolution clauses neither follow consistent, firm-wide company policies, nor are they greatly influenced by the general counsel. Instead, there is ample evidence to support the influence of law firms on the presence of dispute settlement provisions.

\section{STICKINESS AND FIRST-MOVER ADVANTAGE}

When drafting their agreements, law firms work off templates. The stickiness hypothesis suggests that the use of templates induces path dependence. ${ }^{143}$ That is, whatever provision is found in the law firm template is more likely to end up in the final agreement. Conversely, under the null hypothesis of no stickiness, the allocation of rights under the template should have no relevance on the final contract, given that parties can simply bargain over and contract around the initial draft of the agreement.

In order to assess whether law firms indeed negotiate dispute settlement provisions, I conduct an analysis on all contracts between two law firms. Consider one such contract between law firms $X$ and $Y$, for which I proceed in the following three steps:

(1) Identify all contracts that $X$ has drafted in the previous year without the participation of $Y$, as well as those that $Y$ has drafted without participation of $X .{ }^{144}$

141 In unreported results, I employ an alternative estimation strategy referred to as "instrumental variables," in which the law firm collapse is used as a (strong) instrument for the change of law firms. The estimation yields consistent results.

142 Even though the coefficient has the predicted sign, the effect size is miniscule, about $1.7 \%$. It is also statistically insignificant, even though the confidence intervals are small. Both of these findings ameliorate concerns arising out of difficulties typical to interpreting "null results," such as a lack of statistical power.

143 See generally Marcel Kahan \& Michael Klausner, Path Dependence in Corporate Contracting: Increasing Returns, Herd Behavior and Cognitive Biases, 74 WASH. U. L.Q. 347 (1996).

144 Subsetting only to those contracts that $X$ has drafted without $Y$ guarantees that the most similar contract of $X$ has not been influenced by $Y$ in any way. To guarantee 
(2) Compute how similar the text of the present contract is to the text of the agreements that the parties have drafted in the past.

(3) Identify the law firm that has drafted the most similar past agreement.

In order to measure the textual similarity of the agreements, I rely on a fuzzy string matching algorithm to compare the first $10 \%$ of text in the agreements. ${ }^{145}$ Fuzzy string matching is a method of text comparison that ignores discrepancies, which are typically induced by typos or small, context-specific adjustments (such as changing the name of the party). ${ }^{146}$ It thus tends to perform much better at identifying essentially identical text strings than other approaches found in the literature, ${ }^{147}$ such as the Levenshtein distance or cosine similarity. ${ }^{148}$

After fuzzy string matching, each pair of contracts is associated with a number, ranging from zero (entirely dissimilar) to one hundred (identical). I manually inspected the results and found that a value of ninety or greater guarantees that two agreements are virtually identical copies of one another.

Having thus found a reliable way of identifying who supplied the first draft, we can assess whether law firms bargain over the inclusion and form of dispute settlement provisions. Under

comparability and computational feasibility, I omit previous agreements of a different type or drafted for clients in another industry.

145 Comparing only the first $10 \%$ follows substantive and practical considerations. First, the first $10 \%$ predominantly contains recitals, tables of contents, etc., such that templates can be identified even if the substantive terms are considerably different. Second, limiting the comparison to the first $10 \%$ guarantees that the dispute resolution clause itself does not factor into the comparison. And third, as comparing contracts pairwise for such a large data set is computationally intensive, limiting the analysis to the initial $10 \%$ guarantees feasibility.

146 The Python implementation, FuzzyWuzzy, is available at FuzzyWuzzy, GitHuB, https://perma.cc/S4X6-5R3R. Among the different algorithms, I opt for the token-set ratio. In essence, the token-set ratio compares strings based on their unique terms while ignoring the order in which these terms appear.

147 Robert Anderson \& Jeffrey Manns, The Inefficient Evolution of Merger Agreements 18-20, 27-28, 38 (2016) (unpublished manuscript) (on file with author) (using Levenshtein Distance as a measure of copy-pasting in M\&A agreements and arriving at the much contested conclusion that most of what lawyers do is "editorial churning" rather than substantively meaningful editing).

148 See, e.g., Chaiyong Ragkhitwetsagul, Jens Krinke \& David Clark, A Comparison of Code Similarity Analysers, 23 EMPIRICAL SOFTWARE ENG'G 2464, 2489 (2018) (investigating the performance of fuzzy string matching in identifying plagiarism in software code and finding that it outperforms eight out of nine other detection tools). For use cases and examples, see FuzzyWuzzy: Fuzzy String Matching in Python, CHAIRNERD (Jul. 8, 2011), https://perma.cc/PLN2-7RGB. 
traditional bargaining theory and absent stickiness, a law firm that typically uses dispute resolution clauses in its contract (and thus has a revealed preference for the use of these provisions) should try to amend a draft that includes a contractual gap. In contrast, under the stickiness hypothesis, the presence of dispute settlement provisions in the initial draft should be predictive of its presence in the final contract.

FIGURE 5: FIRST DRAFTER ADVANTAGE

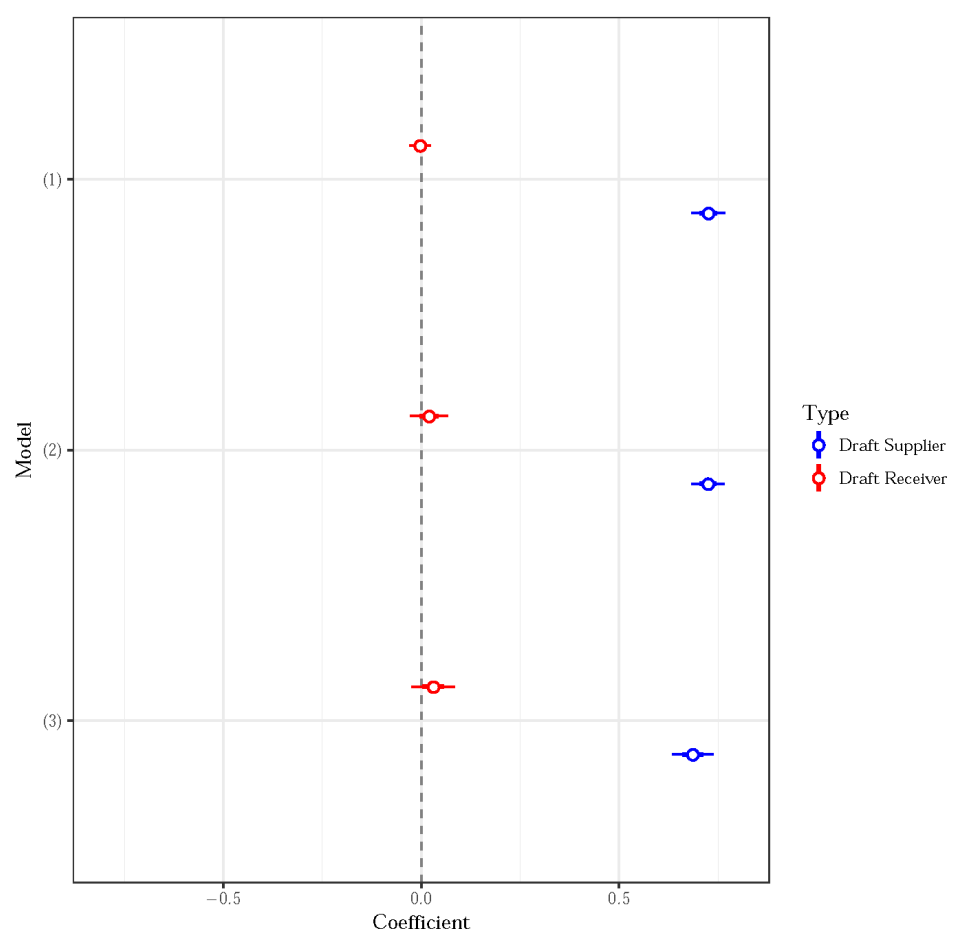

The results of the analysis are depicted in Figure 5. All models consider only contract pairs in which the most similar agreement from one law firm had a similarity greater than or equal to ninety and the most similar draft from the other had a similarity of seventy or less. This requirement guarantees that the supplier of the first draft can be identified with great accuracy. ${ }^{149}$

Model (1) investigates how likely it is that a contract includes a dispute settlement provision if the identified template specified

149 Based on my manual inspection of the results. 
the forum (blue). It then contrasts this with the probability of finding a dispute settlement provision if the most similar contract from the nonsupplier specified the forum (red). The results are striking. If the template includes a dispute resolution clause, this increases the probability that the present contract includes such a clause by seventy-two percentage points, from a baseline of fifteen percentage points to eighty-seven percentage points. Meanwhile, the influence of the most similar contract from the other law firm has virtually no influence on the present agreement.

Model (2) compares the template influence to the average presence of dispute resolution clauses in the draft receiver's agreements. Model (3) compares the template's influence to the average influence of contracts for which the other law firm has supplied the first draft. Again, in both model specifications, the presence of a dispute settlement provision in the template is highly predictive of whether the present agreement includes such a clause. At the same time, none of the model specifications indicates a significant influence of the preferences of the law firm that did not supply the first draft.

Overall, the evidence strongly suggests that the first draft is highly predictive of the provisions in the final agreement. Whatever discrepancy there may be between the draft and the final contract, there is no evidence that this discrepancy correlates with the revealed preferences of the nonsupplying law firm.

\section{RESISTANCE TO CHANGE}

The governing theory on the innovation in the design of boilerplate agreements postulates that changes in the contractual templates may require external, system-wide shocks-like changes in the legal framework - to cause a change in the adaption of the template. ${ }^{150}$ The system-wide shock that I consider is a change in the law surrounding choice-of-forum provisions and personal jurisdiction. Specifically, the relevant legal framework underwent two important changes in the period of observation. First, the Supreme Court began to significantly restrict the scope of both general and specific jurisdiction through a series of decisions going back to 2010. Second, the Supreme Court removed

150 For a specific analysis in the context of procedural choice, see David A. Hoffman, Whither Bespoke Procedure?, 2014 U. ILL. L. REV. 389, 425-29. See also generally Choi et al., Evolution of Contractual Terms, supra note 28; Choi et al., Dynamics of Contract Evolution, supra note 28; Florencia Marotta-Wurgler \& Robert Taylor, Set in Stone? Change and Innovation in Consumer Standard-Form Contracts, 88 N.Y.U. L. REV. 240 (2013). 
uncertainty surrounding the enforcement of dispute settlement provisions in 2013. Each intervention will be described in the necessary detail below.

\section{A. Limits on Personal Jurisdiction}

As pointed out in Part I, courts tended to broadly interpret personal jurisdiction under both principles of general and specific jurisdiction. Under general jurisdiction, many courts applied a "doing business" test, which holds that it is sufficient for a company to do business "with a fair measure of permanence and continuity" in a state in order for the courts in that state to exert general jurisdiction. ${ }^{151}$ Under specific jurisdiction, long-arm statutes employ criteria such as the transaction of business that were sufficient to establish jurisdiction. In practice, there often is not much distinguishing the "transacting business" test from the "doing business" test.

In 2011, the Supreme Court started to take aim at these expansive approaches to personal jurisdiction in the name of due process. The first case was Goodyear Dunlop Tires Operations, S.A. v. Brown, ${ }^{152}$ which was decided in June 2011. In that case, plaintiffs were the estates of two Americans killed in a bus accident in France. They alleged that faulty tires were to blame, and proceeded to sue the manufacturers, Goodyear's affiliate in Luxembourg and its branches in Turkey and France, in the courts of North Carolina. The plaintiffs argued that North Carolina courts had personal jurisdiction because the defendants' parent company and distributor, Goodyear USA, is a U.S. company. Goodyear USA operates plants and is commercially active in North Carolina, but the subsidiaries argued that their parent company's activity was not sufficient to establish jurisdiction over them.153 In a unanimous decision written by Justice Ruth Bader Ginsburg, the Supreme Court sided with the defendants, holding that a company's connections to a state must be so "continuous and systematic' as to render them essentially at home" in the state exerting general jurisdiction. ${ }^{154}$ While the specific circumstances in Goodyear left some doubt as to the decision's generalizability, the subsequent decision of Daimler AG v. Bauman ${ }^{155}$ made it abundantly

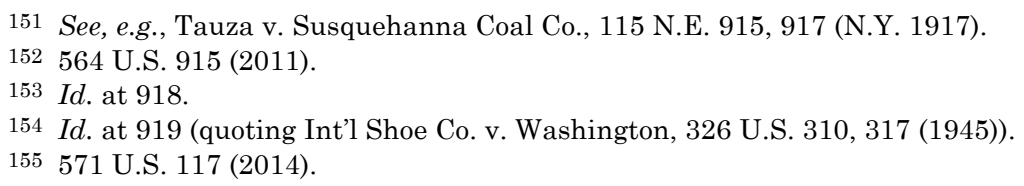


clear that the "essentially at home" test would be the new test courts were required to apply when determining general jurisdiction, in place of the "doing business" test. ${ }^{156}$

In parallel to its reduction of general jurisdiction, the Supreme Court also limited the scope of specific jurisdiction. Decided on the same day as Goodyear, J. McIntyre Machinery, Ltd. v. Nicastro ${ }^{157}$ was a products liability suit brought by Robert Nicastro, a worker in New Jersey. Nicastro had injured his hand when using a metal-shearing machine produced by McIntyre Machinery, a British company. McIntyre Machinery had very few connections to the United States. It sold machines through an independent U.S. contractor, only four of which ended up in New Jersey. Its officials attended annual conventions, none of which took place in New Jersey. And it held some U.S. patents on its recycling technology. ${ }^{158}$

The New Jersey Supreme Court sought to base personal jurisdiction on the "stream-of-commerce" doctrine, holding that the mere act of placing goods in the stream of commercial activity with the expectation that they will end up in New Jersey would be sufficient to establish specific jurisdiction. The plurality opinion rejected that view, holding that due process requires the defendant to "purposefully avail" itself of the benefits of a state's laws in order to establish jurisdiction. ${ }^{159}$ Entering goods into the stream of commerce alone would not suffice. Then, in BristolMyers Squibb Co. v. Superior Court, 160 the Supreme Court stopped attempts by California courts to apply a "sliding scale" approach to the interpretation of specific jurisdiction. Under this approach, California courts sought to argue that doing business in a state was a relevant and sufficient factor to establish specific jurisdiction, effectively mimicking the "doing business" test under general jurisdiction. ${ }^{161}$

This line of Supreme Court decisions shows a general concern for expansive theories of personal jurisdiction. To be sure, it is

156 Id. at $138-39$.

157564 U.S. 873 (2011) (plurality opinion).

158 Id. at 878 .

159 Id. at 886 ("[The defendant's contacts with the United States] may reveal an intent to serve the U.S. market, but they do not show that J. McIntyre purposefully availed itself of the New Jersey market."). Two other justices concurred in the judgment along similar lines, but cautioned the plurality against formulating "broad pronouncements that refashion basic jurisdictional rules.” Id. at 889-90 (Breyer, J., concurring in the judgment).

160137 S. Ct. 1773 (2017).

161 Id. at $1778-89$. 
important to note that none of these decisions is a contracts case. Indeed, the last time the Supreme Court directly addressed personal jurisdiction in a contracts case was in its 1985 decision in Burger King Corp. v. Rudzewicz. ${ }^{162}$ However, there is ample evidence to support that the Supreme Court's decisions had direct implications for the litigation of contractual claims as well, as indicated by several contracts cases in which courts directly reference the Supreme Court opinions to deny jurisdiction. ${ }^{163}$ In addition, law firms urged their clients to carefully consider putting forum selection clauses into their contracts, as some jurisdictions would be more difficult to access in the future. ${ }^{164}$

\section{B. Affirming Enforceability of Forum Selection Clauses}

A second important change in the law on forum selection clauses came in the form of Atlantic Marine Construction Co. $v$. U.S. District Court. ${ }^{165}$ Atlantic Marine Construction, a Virginia

\footnotetext{
162471 U.S. 462 (1985).

163 See, e.g., Blustein v. Akam, 61 N.Y.S.3d 190, 190 (Sup. Ct. 2017) (denying that registering to do business in New York is sufficient to establish personal jurisdiction over a defendant in a breach of contract case, with references to Daimler and Goodyear); Trodale Holdings LLC v. Bristol Healthcare Invs., L.P., No. 16 Civ. 4254 (KPF), 2017 WL 5905574, at *9-10 (S.D.N.Y. Nov. 29, 2017) (applying the "essentially at home" test to deny jurisdiction over companies incorporated in Georgia and Tennessee); Letom Mgmt. Inc. v. Centaur Gaming, LLC, No. 17 Civ. 3793 (PAE), 2017 WL 4877426, at *4 (S.D.N.Y. Oct. 27,2017 ) (denying general jurisdiction over a defendant incorporated in Indiana under the "essentially at home" test).

164 See, e.g., Kelly S. Foss, Suing Foreign Entities in NY: Changes to the Law of Personal Jurisdiction, HARRIS BEACH (Sept. 19, 2017), https://perma.cc/NB2F-LN6D:
}

[After Daimler,] New York-based companies ... should consider carefully whether a forum selection clause is necessary to protect their right to have potential future disputes resolved by the courts located in New York.

. .

Without a forum selection clause to invoke, domestic entities must understand that the well-known "doing business" / "minimum contacts" tests are no longer good law.

See also, e.g., Christopher Renzulli \& Peter Malfa, Choice of Law Provisions, For THE DEF., June 2014, at 30, 35 ("The Supreme Court decision in Daimler AG v. Bauman is a turning point in personal jurisdiction precedent. . . Provisions in contracts dealing with jurisdiction, such as consents to personal jurisdiction and jurisdictional waiver clauses, have become ever more important when drafting agreements with national corporations or local subcontractors."); Liz McOmber, Location, Location, Location-A Brief Overview of Personal Jurisdiction, Forum Selection Clauses, and Why They Matter, SNELL \& WILMER (Aug. 9, 2016), https://perma.cc/5K5S-M5EU (highlighting a change in personal jurisdiction through Daimler and stating that "[c]ompanies [ ] should apply careful scrutiny when crafting, negotiating, or agreeing to forum selection clauses as a preemptive measure to ensure that any dispute is brought in a favorable forum, or at least a neutral one").

165571 U.S. 49 (2013). 
corporation, entered into a construction contract with J-Crew Management, a Texas corporation. The construction contract included a forum selection clause providing that all disputes "shall be litigated in the Circuit Court for the City of Norfolk, Virginia, or the United States District Court for the Eastern District of Virginia, Norfolk Division." 166 J-Crew subsequently sued Atlantic Marine in the Western District of Texas for payments under the contract.

At its core, the issue in Atlantic Marine was how to enforce a contractual choice-of-forum provision and how much weight courts were required to assign to it in the analysis. The district court and the Fifth Circuit argued that a $\S 1404$ (a) motion to transfer is the exclusive mechanism to enforce forum selection clauses referring parties to another federal forum. Further, they held that a $\S 1404$ (a) motion requires a balance-of-interests test in which forum selection clauses are but one of several factors. Lastly, they held that the burden of proof to show that a venue is improper lies on the defendant.

The Supreme Court agreed that choice-of-forum provisions referring parties to another federal court are enforceable under $\S 1404$ (a) motions to transfer. However, it held that these provisions must be "given controlling weight in all but the most exceptional cases" 167 and that the burden of proof to show the existence of an exceptional case lies with the party defying the contractual agreement. The same standards apply to the forum non conveniens analysis applicable to clauses referring parties to another state court. 168

In the eyes of practitioners, Atlantic Marine "significantly clarified the law regarding enforcement of forum-selection clauses." 169 It removed procedural uncertainties arising from the different ways in which courts of appeals have traditionally enforced these provisions, and it strengthened the confidence of private parties that their choice-of-forum provisions would be enforced by federal courts. "After Atlantic Marine, lawyers should

$166 I d$. at 53 (quotation marks omitted).

167 Id. at 60 (quotation marks omitted) (quoting Stewart Org., Inc. v. Ricoh Corp., 487 U.S. 22, 33 (1988) (Kennedy, J., concurring)).

168 Id. ("Section 1404(a) is merely a codification of the doctrine of forum non conveniens for the subset of cases in which the transferee forum is within the federal court system.").

169 Edward S. Sledge, IV \& Christopher S. Randolph, Jr., Maneuvering to Terrain: Enforcement of Forum-Selection Clauses After Atlantic Marine, 75 ALA. LAW. 229, 231 (2014). 
feel comfortable inserting and relying on the enforceability in federal court of restrictive forum-selection clauses." 170

\section{The Effect of Judicial Interventions}

The implications arising from the judicial interventions by the Supreme Court during the period of observation are twofold. First, the Court made it more difficult for parties to establish both general and specific jurisdiction, in turn decreasing the number and variety of jurisdictions plaintiffs have access to absent a forum selection clause. Second, forum selection clauses became more reliable instruments of choice to guarantee that a dispute would be heard in the jurisdiction preferred by the parties. Both of these circumstances affect the cost-benefit calculation of including or omitting a forum selection clause from an agreement. Absent stickiness, we would expect law firms to increase their use of choice-of-forum provisions pursuant to the Supreme Court intervention. However, if contracts are sticky, law firms might hold on to their practice irrespective of changes in the costs and benefits associated with their choice.

To examine the law firm's reaction to the Supreme Court decision, I employ a time series analysis. In particular, to examine whether forum selection clauses became more prevalent overall, I first plot the quarterly rate of forum selection clauses in all material contracts up to the point in time when the Supreme Court intervened. Next, through the use of an ARIMA model, ${ }^{171}$ I predict how the time series is expected to continue based on the preintervention data. Lastly, I compare the predicted rate of forum selection clauses under the assumption that there has been no intervention by the Supreme Court to the observed rate of forum selection clauses under the Supreme Court's intervention.

Naturally, this proposed analysis requires me to specify at what point in time the Supreme Court intervention took place. As it is generally preferable to specify an intervention that is too early, rather than too late, ${ }^{172}$ I use the point in time of the earliest decisions, Goodyear and Nicastro, which were decided in June

170 Scott Dodson, Forum-Selection Clauses After Atlantic Marine, 78 ADvocATE 21, 22 (2017).

171 George E. P. Box, GWilym M. Jenkins, Gregory C. Reinsel \& GreTA M. LJUnG, Time SERIES ANALYSis: FoRECASTING AND CONTROL 94-96 (David J. Balding et al. eds., 5th ed. 1970).

172 If the hypothesized intervention takes place before the observed intervention, then the ARIMA model will still use only untreated observations for its prediction. 
2011. However, one might be concerned with treating Goodyear and Nicastro as the appropriate and most significant interventions. After all, as has been pointed out, Goodyear addresses the establishment of general personal jurisdiction, and while I pointed to several cases which suggest the Goodyear analysis matters for contracts disputes, ${ }^{173}$ it is more common for parties to rely on specific jurisdiction in contracts cases. For specific jurisdiction, however, it is more difficult to directly pinpoint when parties and lower courts became aware of the Supreme Court's hostility toward expansive views of jurisdiction. That is why, in addition to a hypothesized intervention under Goodyear, I specify an alternative time of intervention at the point where Atlantic Marine was decided-i.e., in December 2013.

FIGURE 6: ARIMA MODEL PRE- AND POST-GOODYEAR

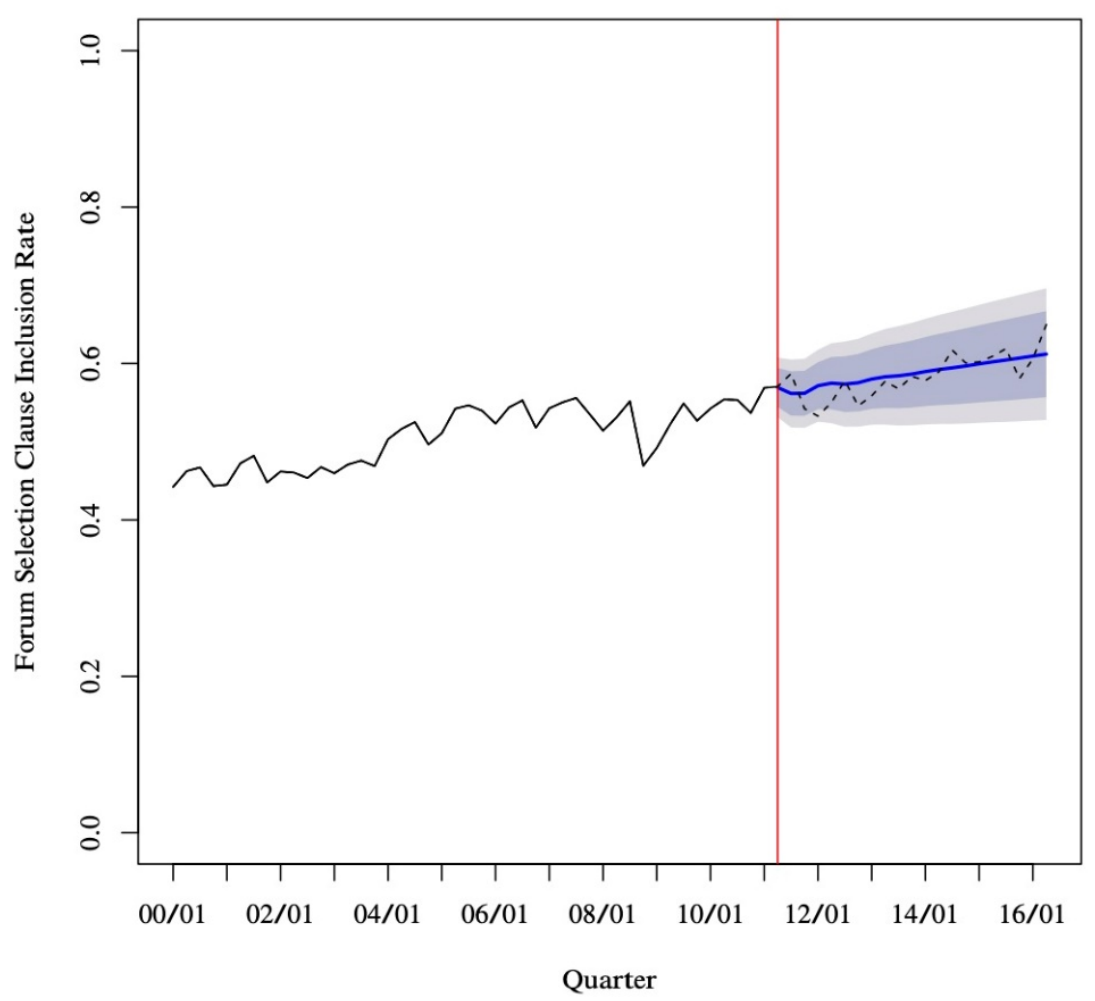

173 See supra note 163. 
Figure 7: ARIMA MODEL PRE-AND Post-ATLANTIC MARINE

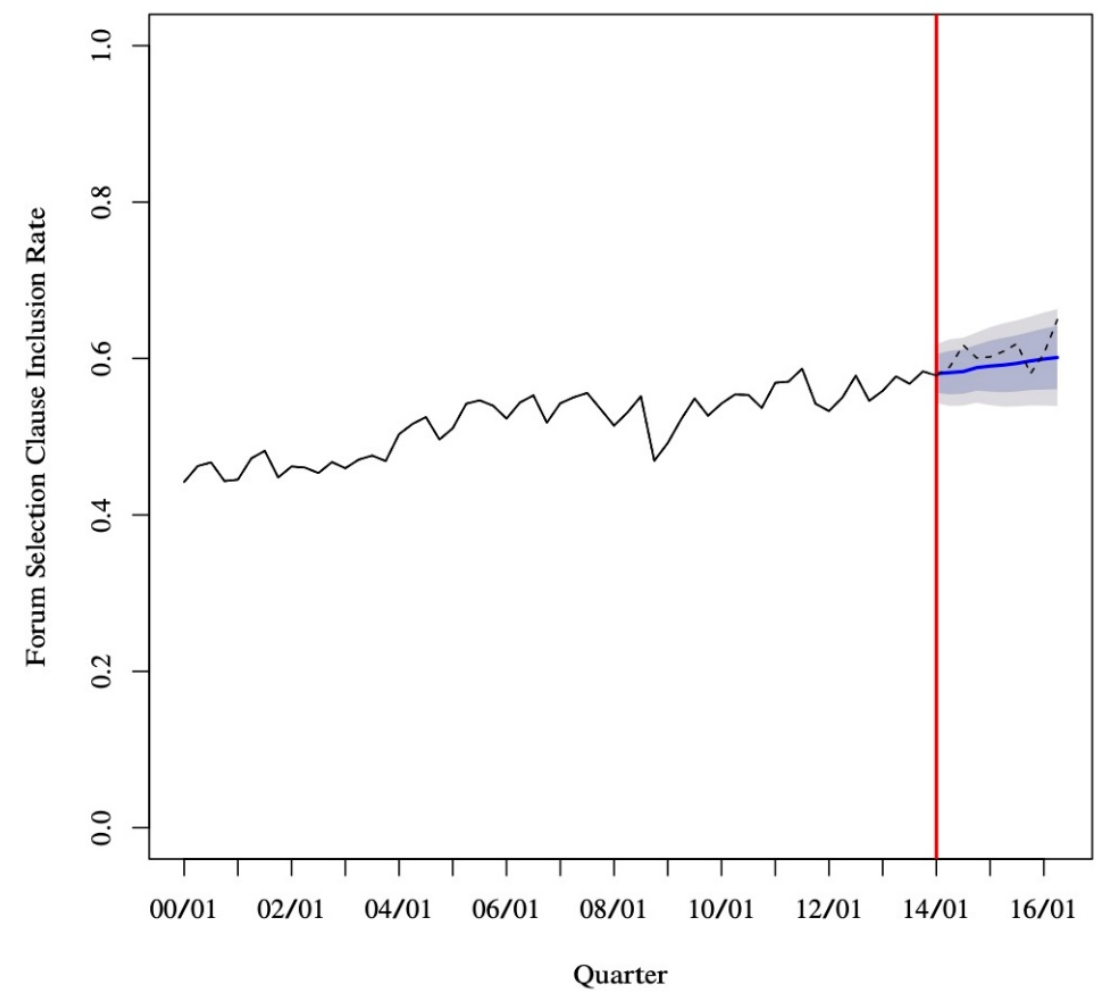

Figure 6 depicts results under the assumption that the relevant period of intervention is Goodyear. Figure 7 assumes that the relevant intervention is Atlantic Marine. As can be seen, the observed rate of forum selection clauses does not fall outside of the predicted rate based on preintervention observations. Hence, there is no evidence to support the notion that the overall inclusion rate of forum selection clauses is susceptible to nuanced changes in the relevant legal framework.

One might contend that it is difficult to find an effect of judicial intervention because the Supreme Court decisions have heterogeneous effects for different types of contracts. Both the "essentially at home" test under general jurisdiction, as well as most long-arm statutes, take into consideration how closely a company is linked to the jurisdiction of the plaintiff's choice. Forum selection clauses thus are especially important to companies with weak ties to their preferred jurisdiction. This means that the incentives to include a forum selection clause should be especially 
pronounced for companies that intend to litigate in a forum that is neither the principal place of business nor the place of incorporation for any of the parties. For others, the change in the law might be less critical. ${ }^{174}$

This suggestion, too, is testable. What follows from it is the hypothesis that the judicial intervention should have had a strong effect on the frequency with which forum selection clauses are used that refer parties to courts outside of the state of incorporation and principle place of business ("outside forum selection clause"). At the same time, the rate of forum selection clauses referring parties to the principal place of business or place of incorporation ("inside forum selection clauses") should remain unaffected.

Distinguishing between inside and outside forum selection clauses yields two different time series. We can compare these time series to examine whether the judicial intervention had an effect. In particular, if the time series show similar movement prior to the intervention but diverge after the intervention, then this is evidence that the judicial opinions influenced the prevalence of outside forum selection clauses. In contrast, if the movement is similar prior to the intervention and after the intervention, this suggests that there is no evidence of an effect due to judicial intervention. ${ }^{175}$

174 Albeit still of some relevance.

175 I employ the synthetic controls method for this test in order to align the two time series on preintervention data. See Kay H. Brodersen, Fabian Gallusser, Jim Koehler, Nicolas Remy \& Steven L. Scott, Inferring Causal Impact Using Bayesian Structural TimeSeries Models, 9 ANNAls ApPliED STAT. 247, 252 (2015). 
FIgURE 8: SyNTHETIC CONTROLS ANALYSIS PRE- AND POST-

GOODYEAR

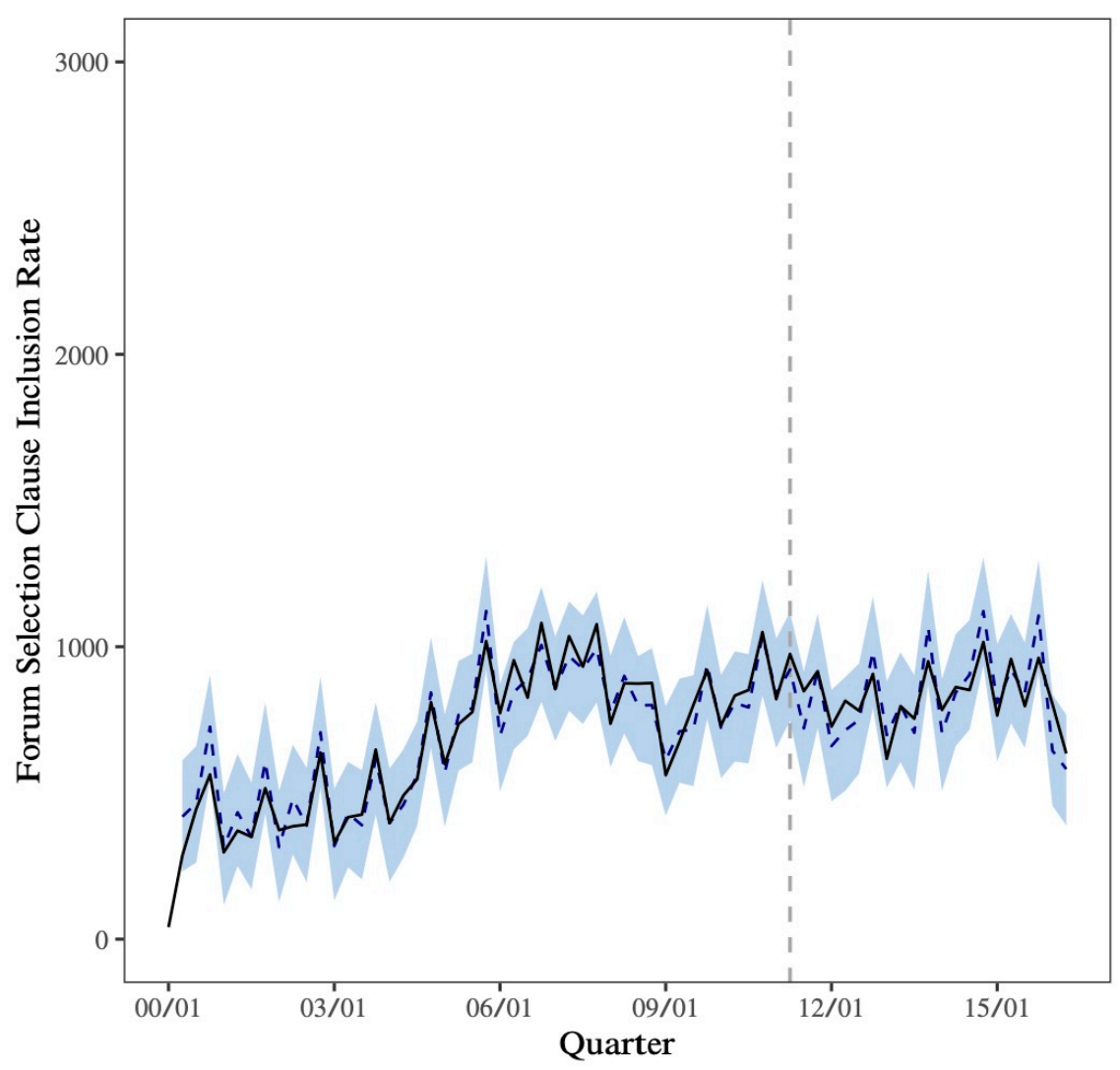


Figure 9: SyNTHETIC CONTROLS ANALYSIS PRE-AND POSTATLANTIC MARINE

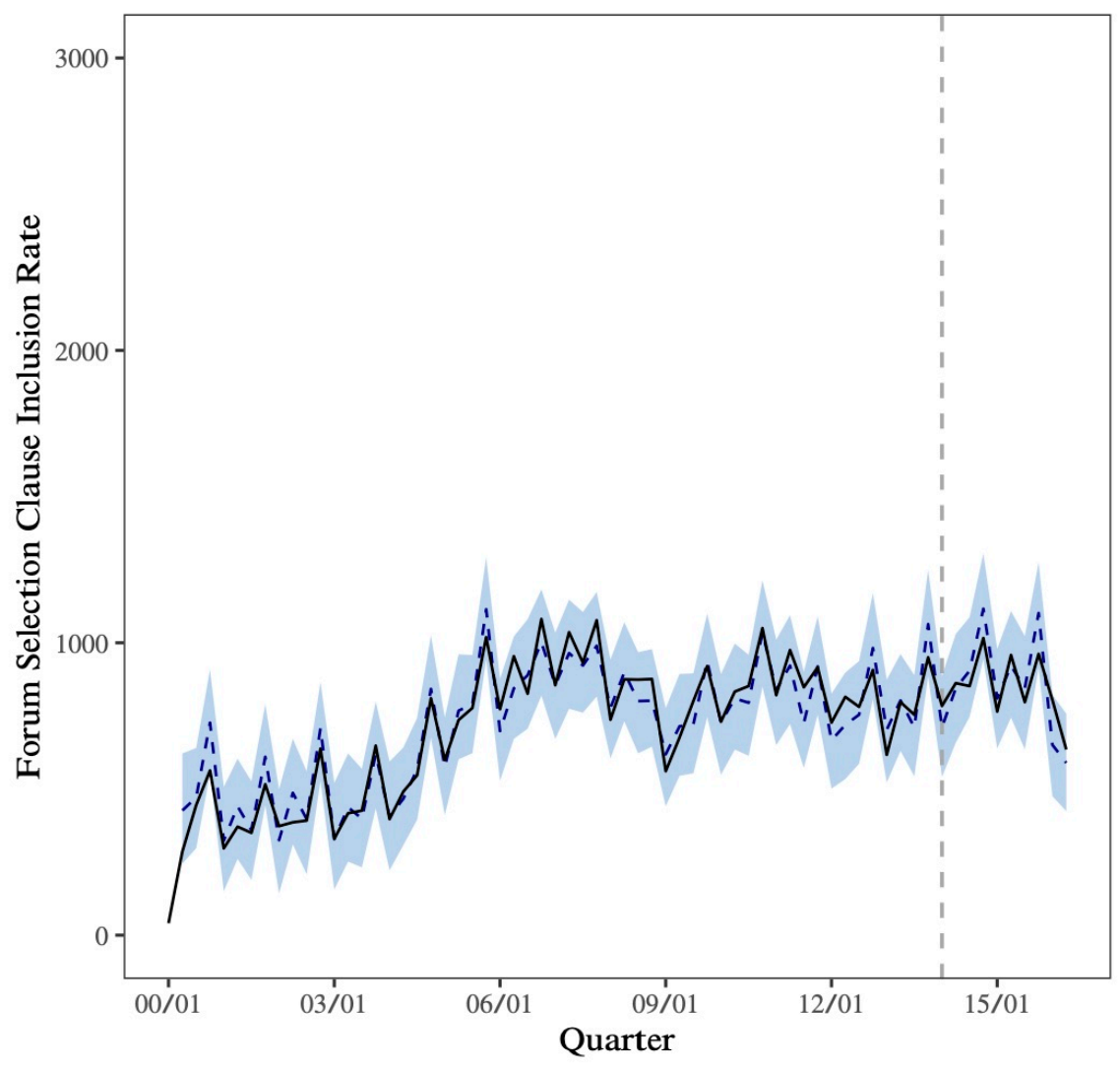

Figures 8 and 9 show the results. As can be seen in Figure 8, pre-Goodyear, the time series for inside forum selection clauses (after implementing the synthetic controls method) tracks the prevalence of outside forum selection clauses closely, indicating that the time series used as a control unit is a good comparator in terms of the outcome measure. After Goodyear, the two time series still move together, which suggests that Goodyear had no differential impact on inside and outside forum selection clauses. As such, even the contracts that, based on theoretical considerations, should be especially sensitive to changes in legal framework show no indication that Goodyear had any relevant effect. As in Figure 7, Figure 9 investigates whether Atlantic Marine may be the relevant decision, but again, no significant changes can be detected. 
Overall, there is no evidence to support the hypothesis that subtle changes in the legal framework matter for the inclusion of choice-of-forum provisions. This finding is consistent with previous results in the literature that show that the language in pari passu clauses is resistant to changes in the law. ${ }^{176}$ Similarly, it has recently been found that the language in corporate bond choice-of-law provisions referring parties to New York is insensitive to changes in the relevant jurisprudence. ${ }^{177}$

\section{LIMITATIONS \& NORMATIVE IMPLICATIONS}

Using the example of dispute resolution clauses, this empirical analysis reveals strong support for the stickiness hypothesis. The findings are thus at odds with much of the traditional literature as well as judicial reasoning on the drafting of contracts. Both typically ignore the role and preferences of the law firm entirely, instead assuming that the final allocation of the contractual surplus will be optimized. ${ }^{178}$ With that said, it is important to recognize and acknowledge important limitations of this study in order to adequately contextualize the findings.

First, findings of contractual gaps may be somewhat influenced by the phenomenon of attempted incorporation by reference. ${ }^{179}$ In more complex contractual relationships, parties may conclude a series of contracts and then specify an "entire agreement" clause that stipulates that all contracts together form the

\footnotetext{
176 See GULATI \& SCOTT, supra note 28, at 122-24.

177 See John F. Coyle, Choice-of-Law Clauses in US Bond Indentures, 13 CAP. MKTS. L.J. 152, 158-59 (2018) (discussing a 2010 decision of the New York Court of Appeals that held that statutes of limitations are procedural and thus are not incorporated automatically by inclusion of a choice-of-law provision). Professor Coyle hypothesizes that because fifty interviews revealed that the vast majority of attorneys would want their choice-oflaw provision to extend to statutes of limitations, attorneys would need to adapt their language accordingly.

[However, v]irtually none of the indentures in the data set address the distinction between substantive law and procedural law. Only 2 per cent of these indentures contained language incorporating the procedural law of New York. This omission would not matter overmuch if the indentures all contained exclusive forum selection clauses requiring all disputes to be litigated in New York. However, the majority of the indentures lacked any sort of forum selection clause.

Id. at 159 .

178 See supra notes $23,54-56$ and accompanying text.

179 I am grateful to Professor Joe Grundfest for raising this concern and for fruitful discussions in connection with it.
} 
entire agreement. ${ }^{180}$ It is at least conceivable that parties, through the entire agreement clause, intend to incorporate dispute settlement provisions from the agreement in which they are present into the agreement in which they are absent. This Article identifies only the presence or absence of dispute resolution clauses. It does not track entire agreement clauses. With that said, relevant case law suggests that courts in New York, Delaware, and other jurisdictions have rejected the notion of incorporation by reference as it pertains to choice-of-forum provisions, as these are held to require a specific intent manifested in the specific agreement in question. ${ }^{181}$ So even to the degree that parties have relied on incorporation by reference, their reliance appears misguided and would induce unnecessary and avoidable risk.

In addition, to rule out that significance of incorporation by reference, I have manually reviewed 127 agreements without choice-of-forum provisions for the presence or absence of choiceof-forum provisions in any of the contracts referenced in the entire agreement clause. I was able to identify only six instances in which a plan of merger agreement included an entire agreement clause referencing documents I was unable to find. In all other instances, I was able to definitively rule out an incorporation by reference. In a last step, as an excessively conservative solution, I dropped from my analysis all instances in which multiple agreements had been filed between the same parties in the same year. My results remained substantially identical.

180 Royce de R. Barondes, Side Letters, Incorporation by Reference and Construction of Contractual Relationships Memorialized in Multiple Writings, 64 BAYLOR L. REV. 651, 657-77 (2012) (detailing incorporation by reference).

181 See CooperVision, Inc. v. Intek Integration Techs., Inc., 794 N.Y.S.2d 812, 816-17 (Sup. Ct. 2005) (rejecting the argument that a forum selection clause in a software license agreement is incorporated by reference into an implementation agreement). The implementation agreement in CooperVision included an entire agreement clause stating: "This Agreement, the Order Acknowledgment in Schedule A, Software License Agreement, and Warehouse Analysis document represent the entire contract." See also Newport Disc, Inc. v. Newport Elecs., Inc., No. N12C-10-228 MMJ CCLD, 2013 WL 987936, at *4 (Del. Super. Ct. Mar. 11, 2013) (quoting CooperVision, Inc., 794 N.Y.S.2d at 819):

The "mere reference" to a second agreement as part of the "entire agreement" of the parties, without an "express provision" incorporating the forum selection clause, reflects the parties' intention that the forum selection clause does not apply to disputes arising from the first contract. Absent a clear intention to the contrary, an integration clause should be interpreted to limit the forum selection clause to the agreement containing the forum selection clause.

See also, e.g., Valero Mktg. \& Supply Co. v. Baldwin Contracting Co., No. H-09-2957, 2010 WL 1068105, at*4-5 (S.D. Tex. Mar. 19, 2010) (rejecting incorporation by reference to General Terms and Conditions). 
A second caveat of this study that deserves attention relates to the breadth of its scope, in which limitations apply across two dimensions. First, this study only considers material contracts involving publicly registered companies. It does not include day-today agreements of smaller value. It may be argued that the latter differ substantially from the sample studied here in ways that have important implications for the issue of forum selection. ${ }^{182} \mathrm{At}$ the same time, it can be assumed that high-value transactions are most likely to be thoroughly scrutinized by the drafters, precisely because the stakes are so high. ${ }^{183}$ If we find evidence to support the stickiness hypothesis even in these high-stakes interactions where the drafters have significant incentives to optimize the provisions, it is at least plausible to assume that the findings can be extrapolated to the set of lower-stakes agreements as well. The sample also does not include contracts involving only private companies. As such, they are not directly extrapolatable to, for instance, lawyers working in private equity.

Second, and more importantly, this study investigates only the use of dispute resolution clauses. Dispute resolution clauses differ from other provisions in several important ways. First, even though they can have important allocative implications, dispute settlement provisions are nonprice terms, which differ in important ways from other contractual clauses. For instance, nonprice terms are typically not included on the initial term sheet, and even though the Supreme Court suggests otherwise, ${ }^{184}$ both practitioners ${ }^{185}$ and standard models of contract drafting ${ }^{186}$

182 See, e.g., Christopher R. Drahozal \& Stephen J. Ware, Why Do Businesses Use (or Not Use) Arbitration Clauses?, 25 OHIO ST. J. DisP. REsol. 433, 455 (2010) (arguing that contracts of smaller value are more likely to rely on arbitration, whereas "bet-thecompany" contracts and other high-volume transactions will refer to litigation (quotation marks omitted)).

183 See Theodore Eisenberg \& Geoffrey P. Miller, The Flight from Arbitration: An Empirical Study of Ex Ante Arbitration Clauses in the Contracts of Publicly Held Companies, 56 DEPAUl L. REV. 335, 349 (2007) ("The importance of the [material agreements] to corporate operations suggests that the contracts receive care and attention when they are negotiated and drafted.").

184 See supra note 55.

185 In interviews conducted in the context of this study, several partners and a general counsel suggested that they would not seek to adjust the price in response to changes in the dispute settlement provisions, because price adjustments require additional approval. They indicated, however, that they would trade off nonprice terms against each other.

186 See Albert Choi \& George Triantis, The Effect of Bargaining Power on Contract Design, 98 VA. L. REV. 1665, 1671 (2012) (detailing a two-stage negotiation process in which price terms are fixed first); Jeffrey Manns \& Robert Anderson IV, The Merger 
agree that nonprice terms cannot realistically be traded off against price terms, but rather present a distinct set of provisions that are bargained for separately. At the same time, law firms tend to play a very limited role in the bargaining process surrounding price terms, ${ }^{187}$ so that any effect induced by external counsel is unlikely to be found in them. Arguably, this makes nonprice terms the more desirable object of study in the present case.

Nonetheless, even though dispute settlement provisions can have important allocative effects, it would certainly be an overstatement to suggest that they are the most significant nonprice terms that determine the welfare gains of the parties. ${ }^{188}$ As such, it is important to recognize that this Article identifies stickiness with respect to a very particular type of clause that has at best moderate allocative implications.

Indeed, there is evidence to suggest that drafters do pay significant attention to some secondary provisions and that these provisions may then be drafted with the utmost care and precision. Perhaps the best example is provided by the ABA's Deal Point Studies. ${ }^{189}$ Here, the Mergers \& Acquisitions Committee investigated the correlation between the buyer power ratio (BPR) and the wording of certain provisions in M\&A contracts. The BPR is simply the buyer's market cap divided by the purchasing price. If a large company buys a small company, the BPR will be high, whereas it will be smaller if the companies are of relatively similar size. The authors of the study show that much of the language in M\&A contracts changes in subtle ways, being more beneficial for the buyer if the BPR is high and the buyer has much bargaining power, and less preferential if the BPR is low. ${ }^{190}$

Nonetheless, the fact that drafters do carefully adjust the language in some nonprice terms does not necessarily imply that

Agreement Myth, 98 CoRNELL L. REV. 1143, 1176 (2013) (describing that nonprice terms typically cannot be traded off against price terms).

187 Choi \& Triantis, supra note 186, at 1671 ("[T] he price and other important terms are decided by the business principals, and the design 'details' are delegated to their respective lawyers.").

188 Generally, the allocative implications of the substantive law are likely to be greater than those of the forum.

189 See generally ABA MERgers \& ACquisitions Comm., IMPACT OF "BuYer Power Ratio" on Selected M\&A Deal Terms in Acquisitions of Privately Held TaRget COMPANies By Publicly TRAdED Buyers (2017).

190 For instance, if the BPR is below 10, the probability to find an express exclusion of consequential damages from the indemnifiable damages is about 0.5 , whereas it decreases to 0.2 if the BPR is greater than 200. $I d$. at 37 . 
the clauses that receive the most attention are economically significant. For instance, one of the most heavily investigated and bargained-over provisions in M\&A transactions is the material adverse change (MAC) clause. In essence, MAC clauses specify the conditions under which a buyer may walk away from a deal if specific adverse events occur between the time of the signing of the agreement and the closing that negatively impact the target company. MAC clauses are the frequent subject of scholarly interest, ${ }^{191}$ and the ABA Deal Point Study shows that MAC clauses are carefully drafted to reflect the BPR. However, the first relevant case in which a Delaware court allowed a buyer to actually invoke the MAC clause in order to walk was in October 2018.192 Prior to this point, courts had been hesitant to entertain the thought that a material adverse event occurred, even if quarterly results after signing a deal dropped significantly. ${ }^{193}$ Hence, even though the distributional consequences of a material adverse change might be severe if it occurs, one may raise doubts as to whether MAC clauses really are of profound economic relevance, given the high standard that needs to be met. ${ }^{194}$ Contrast this to dispute resolution clauses, which, in addition to their relevance in optimizing performance, ${ }^{195}$ have economic implications whenever a contract-related dispute occurs. It is at least conceivable that their economic significance does not significantly differ from that of alternative provisions that receive more attention, such as

191 For just three examples, see generally Eric L. Talley, On Uncertainty, Ambiguity, and Contractual Conditions, 34 DEL. J. CoRP. L. 755 (2009); Robert T. Miller, Canceling the Deal: Two Models of Material Adverse Change Clauses in Business Combination Agreements, 31 CARDOZO L. REV. 99 (2009); Adam B. Chertok, Rethinking the U.S. Approach to Material Adverse Change Clauses in Merger Agreements, 19 U. MiAMI INT'L \& COMPAR. L. REV. 99 (2011).

192 See generally Akorn, Inc. v. Fresenius Kabi AG, C.A. No. 2018-0300-JTL, 2018 WL 4719347 (Del. Ch. Oct. 1, 2018). There is one case in which a court in Tennessee assumed that a material adverse event had occurred, but that it had no impact on the duties of the parties. Genesco, Inc. v. Finish Line, Inc., No. 07-2137-II(III), slip op. at 33 (Tenn. Ch. Dec. $27,2007)$. However, the specific wording of the clause, as well as the fact that the decision comes from the courts of Tennessee, rather than Delaware, means that Genesco lacks precedential value and has received almost no attention. See Daniel Gottschalk, Comment, Weaseling out of the Deal: Why Buyers Should Be Able to Invoke Material Adverse Change Clauses in the Wake of a Credit Crunch, 47 Hous. L. REV. 1051, 1065 (2010).

193 See, e.g., In re IBP, Inc. Shareholders Litig., 789 A.2d 14, 65-71 (Del. Ch. 2001); Hexion Specialty Chems. v. Huntsman Corp., 965 A.2d 715, 736-46 (Del. Ch. 2008).

194 Writing in 2009, David Cheng points out that "no buyer has ever successfully proved a MAC in Delaware" and that buyers should be "cautious about their ability to establish a MAC under Delaware law." David Cheng, Comment, Interpretation of Material Adverse Change Clauses in an Adverse Economy Survey, 2009 ColuM. Bus. L. REV. 564, 598.

195 Supra notes 64-72 and accompanying text. 
MAC clauses. ${ }^{196}$ Ultimately, more research on other types of provisions is necessary to assess the interaction between economic value and stickiness of drafting practices. The methodology of supervised text classification presented in this Article lends itself to such inquiries, making it possible to study drafting practices with respect to virtually any provision that is typically encountered in commercial agreements.

A third limitation, and at the same time another fruitful ground for future research, relates to the unobservability of the substantive mechanism, which causes drafting practices to vary between law firms. As mentioned above, the study of the omission of dispute settlement provisions renders some mechanisms that have previously been proposed in the literature to explain stickiness, such as fear of the unknown or network effects, improbable. ${ }^{197}$ Though it cannot be ruled out with certainty, it appears similarly unlikely that the results can fully be explained by reference to drafting or negotiation costs. ${ }^{198}$ However, there remain at least two ways in which the results may plausibly be understood.

A first interpretation is that the results describe a principalagent dilemma. ${ }^{199}$ A principal-agent dilemma arises when the principal gives discretion to her agent to act on her behalf, but the principal's and the agent's interests do not perfectly align. The principal has the choice to pay certain expenses to align the agent's interest with her own, such as monitoring or a performancebased compensation scheme. ${ }^{200}$ If these measures are insufficient or too costly, the principal may incur a residual loss stemming from the agent's acting in her own self-interest, rather than in the principal's best interest.

Applying this conceptual framework to the present scenario, it may be the case that law firms are granted discretion in

196 To be sure, observed litigation is an equilibrium response and it is possible that the mere shadow of a MAC is sufficient to have important economic consequences. Nonetheless, the impossibility of establishing a material adverse change makes it at least possible that the attention MAC provisions receive does not match their distributional or allocational significance.

197 See supra notes 100-02 and accompanying text.

198 Supra Part II.B.1.

199 Choi et al., The Black Hole Problem, supra note 28, at 58-61 (proposing an agency cost explanation that would make terms unresponsive to changes in the legal environment); see also GULATI \& SCOTT, supra note 28, at 142-51 (discussing stickiness as an agency dilemma).

200 See, e.g., Bengt Holmstrom \& Paul Milgrom, Multitask Principal-Agent Analyses: Incentive Contracts, Asset Ownership, and Job Design, 7 J.L. ECON. \& ORG. 24, 24-29 (1991) (discussing incentive alignment in a multitask employment context). 
designing dispute resolution clauses, but that they lack incentives to use this discretion in their clients' best interest. This, in turn, may then explain why law firms do not, for instance, challenge the absence of dispute settlement provisions in drafts they receive, even though they frequently use these clauses in their own contracts.

An alternative understanding of the findings is that they characterize a cognitive error or inattention on behalf of legal counsel that ultimately leads to inefficient contracting. This characterization is consistent with an explanation provided by Professor John Coates, who found that inexperience of external counsel can explain observed variation in takeover defenses in corporate charters. ${ }^{201}$

The present study provides no definitive answer for what the appropriate causal mechanism is that explains the results. However, some of the evidence is at least suggestive. For one, in interviews I conducted with transactional lawyers, the unanimous expectation was that dispute settlement provisions were included in virtually all material contracts, because leaving the forum unspecified would be "borderline malpractice" and "sloppy." ${ }^{202}$ Strikingly, this sentiment was expressed even by counsel that commonly omitted dispute resolution clauses from their own agreements. Further, a former general counsel of a leading Fortune 500 company noted that he "would always want to specify the forum in advance." Against this backdrop, it seems at least plausible to assume that lawyers are expected to specify the dispute settlement mechanisms in their contracts ex ante and that those who do not make an avoidable error. Such an interpretation would also be consistent with findings by other scholars, which at times revealed profound misunderstandings among transactional lawyers about fundamental aspects of drafting dispute settlement provisions. ${ }^{203}$

With these limitations in mind, it is worth contemplating the important implications the present results have for the

201 Coates, supra note 31 , at 1322.

202 The first quote originates from a senior partner, the second one from a senior transactional attorney. Both work at a leading U.S. law firm. The interview notes are on file with the author.

203 Stipanowich, supra note 86, at 834 n.17 (detailing an encounter with a partner in the transactional department of a leading law firm in Boston who was not aware of the difference between arbitration and mediation). 
development of contract law in general, empirical scholarship on contracts, as well as the legal profession.

The traditional account by which sophisticated actors maximize the joint surplus of the contract and allocate the rights optimally has significant practical consequences. For instance, a belief in the account's descriptive accuracy for how contracts between sophisticated actors are negotiated and drafted can stifle legal innovation, as limited resources and scholarly attention are shifted toward other areas of law in which the need for an intervention seems more pressing. Default rules offer an illustrative case. The popular Coase Theorem assumes that sophisticated parties in high-stakes transactions will simply contract around inefficient default rules, provided that the transaction costs are comparatively small. ${ }^{204}$ This could suggest that there is no pressing need for regulators or the judiciary to invest in optimization of the legal framework. As detailed above, one example for this dynamic are the default rules on personal jurisdiction.

The Supreme Court has been remarkably active in its effort to clarify and fill out the law surrounding personal jurisdiction in both consumer contracts ${ }^{205}$ and torts. ${ }^{206}$ In contrast, the Court has not touched the issue of personal jurisdiction in the context of arms-length contracts, even though the default rules do not always provide much certainty to the parties. A strong belief in the descriptive accuracy of the parties' capability to reach an optimal allocation of contractual rights is consistent with the Court's behavior. After all, the transaction costs for including a dispute settlement provision are low, and parties can simply contract around the default. It may thus seem as if developing the law for commercial contracts is a third-order concern, especially when comparing it to domains in which the bargaining power is unequally distributed ${ }^{207}$ or there is no bargaining at all. ${ }^{208}$ However, the findings of this study suggest that, at least with respect to dispute

204 See generally Coase, supra note 22.

205 See, e.g., Carnival Cruise Lines, Inc. v. Shute, 499 U.S. 585, 588-89 (1991) (enforcing a forum selection clause contained within a ticket for a cruise); AT\&T Mobility LLC v. Concepcion, 563 U.S. 333, 340, 352 (2011) (holding that the Federal Arbitration Act preempted a California rule that prevented class action waivers in arbitration agreements in consumer contracts); Am. Express Co. v. Italian Colors Rest., 570 U.S. 228, 235-36 (2013) (declining to apply an "effective vindication" exception to invalidate merchants' arbitration agreement).

206 See generally, e.g., Bristol-Myers Squibb Co., 137 S. Ct. 1773; BNSF Ry. Co. v. Tyrrell, 137 S. Ct. 1549 (2017); Daimler, 571 U.S. 117; Goodyear, 564 U.S. 915.

207 As is the case for most consumer contracts.

208 As in torts. 
resolution clauses, this reasoning might be misguided. Contractual gaps, and with them the default rules on personal jurisdiction, are sticky and can have an important economic impact even in agreements of very high value. Their significance implies that the default rules deserve more scrutiny than they often receive, as designing and improving on defaults can have important welfare implications.

In addition to its implications for contract theory, the results also speak to the interaction between empirical and theoretical research on contract law. When studying contractual design, there is a tendency in the literature to view a clause's prevalence and longevity as evidence for its optimality. ${ }^{209}$ If the evidence defies an intuitive explanation, theoretical accounts are revised in order to match up the model to the evidence. The consequences of this process are increasingly complicated and nonintuitive theories on the costs and benefits of contractual provisions that become more and more difficult to verify. An example to illustrate this dynamic is the aforementioned case of pari passu. After publishing the finding that the language of pari passu clauses seems to be insensitive to external shocks, ${ }^{210}$ several rational design explanations were proposed. For instance, one account holds that the language is not altered because it may still provide some protection in the future if the institutional framework surrounding sovereign bond contracts changes. ${ }^{211}$ Another account suggests that ambiguity in the language of pari passu clauses may be explained with a desire to fine-tune the probability of breakdowns during restructuring negotiations. ${ }^{212}$ That model rests on a number of important assumptions, including a high degree of asymmetric information.

The findings of this study call into question the virtues of such ex post rationalizations of contract design. As was shown, contracts between even the most sophisticated actors do not

209 See generally Jérôme Barthélemy \& Bertrand V. Quélin, Complexity of Outsourcing Contracts and Ex Post Transaction Costs: An Empirical Investigation, 43 J. MGMT. STUD. 1775 (2006); Eisenberg \& Miller, supra note 120; Rutledge \& Drahozal, supra note 85; Hoffman, supra note 150.

210 See generally GULATI \& SCOTT, supra note 28.

211 See Mark L.J. Wright, The Pari Passu Clause in Sovereign Bond Contracts: Evolution or Intelligent Design?, 40 Hofstra L. REV. 103, 111 (2011) (discussing GULATI \& SCOTT, supra note 28, and arguing that certain formulations of the pari passu clause may offer pro rata protection if the risk of discriminatory settlements increases in the future).

212 See Marcel Kahan \& Shmuel Leshem, Sovereign Debt and Moral Hazard: The Role of Collective Action and Contractual Ambiguity 14-16 (N.Y.U. L. \& Econ. Rsch. Paper Series, Working Paper No. 17-29, 2017). 
necessarily converge on optimality, but instead can include a suboptimal allocation of rights. ${ }^{213}$ As researchers, we need to be mindful of, and clearly distinguish between, the normative and positive aspects of contract theory. Trying to understand why there is a gap between expectation and reality, rather than theorizing it away, could significantly improve our understanding of contractual design. In order to do so, it seems necessary for theoretical models to take into account the role of the law firm as an important, yet often overlooked actor. ${ }^{214}$

Some authors have taken a first step in that direction and have begun to highlight the importance of the law firm for the substantive terms of specific categories of legal documents. This study further adds to said literature, demonstrating that the law firm is a significant actor in many contexts that far exceed the particular domains subject to previous studies, such as the language in $\mathrm{S}-1$ registration statements ${ }^{215}$ or corporate charters. ${ }^{216} \mathrm{At}$ the same time, we still know surprisingly little about law firm preferences during the drafting process and how counsel chooses to allocate her bargaining power and attention. Future research illuminating how law firms form their preferences, and when these preferences differ from their clients', could make significant contributions to both contract theory and jurisprudence on contract law, while at the same time ensuring practical relevance.

The finding that not all law firms seem to draft similar agreements for similar clients also has important implications for legal education. Law schools have often been confronted with claims that they do not prepare students well enough for practice, raising the possibility that a legal education should best be considered a mere signaling device, while the real conveyance of practically relevant skills happens on the job. This criticism has intensified with the 2007 Carnegie Report on the Legal Profession. ${ }^{217}$ The identified heterogeneity in drafting practices demonstrates an opportunity to create value through legal services and the law school's role in it. In particular, young attorneys sometimes spot

213 From the perspective of the parties bound by the contracts.

214 See Elisabeth de Fontenay, Market Information and the Elite Law Firm 8-17 (Apr. 4, 2017) (unpublished manuscript) (on file with author) (developing an informationfocused model that provides a justification for why parties hire elite law firms).

215 Badawi, supra note 32, at 4-9.

216 Romano \& Sanga, supra note 30, at 50-76.

217 See generally William M. Sullivan, Anne Colby, Judith Welch WegneR, Lloyd Bond \& LeE S. Shulman, EDUCATing LAWyers: Preparation For the PROFESSION OF LAW (2007). 
oddities in contracts but conclude that the fault most likely falls with them, given that the template is time-tested and must have been written by lawyers much more experienced than they are. ${ }^{218}$ This is especially concerning given that young lawyers are most likely to be free of a status quo bias, putting them in an ideal position to reassess contract clauses independently and thus correct insufficient but cemented terms. Law schools are best situated to break the resulting cycle of the perpetuation of inefficient contract terms by providing students with the necessary skills and confidence to reevaluate the efficiency of contractual terms in commonly used drafts and propose adjustments where necessary. This, in turn, can substantially increase the value their graduates can create for clients. ${ }^{219}$

\section{CONCLUSION}

This Article is the first to provide comprehensive evidence for the stickiness hypothesis across multiple types of commercial agreements. It is also the first to demonstrate that contractual gaps, rather than written clauses, can be sticky. The stickiness of contractual gaps is the result of a heavy reliance on templates by external counsel during the drafting process, suggesting that default rules are more important than is traditionally assumed. A better understanding of how law firms form their preferences and how these preferences diverge from their clients' can greatly increase the predictions generated from theories of contracting and guarantee that they remain practically relevant.

218 See GULATI \& SCOTT, supra note 28, at 94 (quoting an interview in which a young attorney's faith in the optimality of the template led the attorney to abstain from tampering with the language).

219 See Ronald J. Gilson, Value Creation by Business Lawyers: Legal Skills and Asset Pricing, 94 YALE L.J. 239, 253-56 (1984). 


\section{APPENDIX}

\section{A.I. FormaLIZING INCENTIVE COSTS}

The following formalizes the theory of incentive costs introduced by leaving the forum unspecified.

Assume a contract between potential plaintiff $P$ and potential defendant $D . D$ is contemplating whether to breach the contractual terms, harming $P$ for an amount of $v$, or whether to incur forbearance costs $\gamma$ and comply. It is socially optimal for $D$ to breach if

$$
\gamma>v
$$

Without legal recourse, $D$ will not invest in forbearance. If $P$ has the option to seek legal recourse, she can sue $D$ for damages in the amount of $d$, producing litigation costs of $\delta_{P}+\delta_{D}=\delta$. Now consider the possibility for parties to specify a court forum ex ante, where the forum is denoted $x \in X$. Different forums have different dispute settlement costs and award different damages. Incorporating the possibility of forum selection, we can state that $D$ will breach if

$$
\gamma>d_{x}+\delta_{x}
$$

In order to maximize the joint surplus of the contract, $D$ has to be incentivized to breach only when it is efficient. This condition is satisfied if

$$
v-d_{x}+\delta_{x}
$$

Assuming for simplicity that overdeterrence is as harmful as underdeterrence, parties thus maximize their joint utility and overall welfare if they choose from the set of forums that minimize the difference between harm and the sum of damages and litigation costs, formally

$$
X^{*} \equiv\left\{x \mid x \in X, \operatorname{argmin}_{x} f(x)=d_{x}+\delta_{x}-v\right\}
$$

What about parties that do not choose a forum? They leave the choice where to sue up to $P$, who can choose from all forums that accept jurisdiction under the default rule. Because $P$ has an incentive to maximize her own as opposed to the joint surplus of the contract, there is no guarantee that the forum chosen by $P$ is the one closest to the social optimum. In particular, let $X^{\prime *}$ be the set of forums that $P$ can sue in. Under the default rule, at the minimum this includes $D$ 's state of incorporation and economic headquarters. $P$ will choose to sue in the state in which the 
difference between her damage award and her litigation costs is maximized. This set is defined by

$$
X^{\prime *} \equiv\left\{x \mid x \in X^{\prime}, \operatorname{argmax}_{x} f(x)=d_{x}-\delta_{x, P}\right\}
$$

\section{A.II. REGRESSION RESULTS IN TABULAR FORM}

The following tables depict the numeric regression results for the figures presented in the main paper.

TABLE A.1: LAW FIRM INFLUENCE ON DISPUTE RESOLUTION

\section{Clauses}

\begin{tabular}{|c|c|c|c|c|c|}
\hline & \multicolumn{5}{|c|}{ Dependent Variable: } \\
\hline & \multicolumn{5}{|c|}{ Difference in Dispute Resolution Clause } \\
\hline & (1) & $(2)$ & (3) & (4) & $(5)$ \\
\hline $\operatorname{Diff}_{L F}$ & $\begin{array}{l}0.154^{* * *} \\
(0.017)\end{array}$ & $\begin{array}{c}0.166^{* * *} \\
(0.017)\end{array}$ & $\begin{array}{l}0.133^{* * *} \\
(0.017)\end{array}$ & $\begin{array}{l}0.222^{* * *} \\
(0.029)\end{array}$ & $\begin{array}{l}0.158^{*} \\
(0.067)\end{array}$ \\
\hline $\operatorname{Diff}_{\text {Year }}$ & & $\begin{array}{c}0.002 \\
(0.002)\end{array}$ & $\begin{array}{l}0.005^{* *} \\
(0.002)\end{array}$ & $\begin{array}{l}0.018^{* * *} \\
(0.004)\end{array}$ & $\begin{array}{l}0.038^{*} \\
(0.016)\end{array}$ \\
\hline Constant & $\begin{array}{l}0.228^{* * *} \\
(0.017)\end{array}$ & $\begin{array}{c}0.133^{* * *} \\
(0.017)\end{array}$ & & & \\
\hline $\begin{array}{l}\text { Exact } \\
\text { Matching }\end{array}$ & & $\checkmark$ & $\checkmark$ & $\checkmark$ & $\checkmark$ \\
\hline Industry FEs & & $\checkmark$ & $\checkmark$ & $\checkmark$ & $\checkmark$ \\
\hline $\begin{array}{l}\text { Contract } \\
\text { Type FEs }\end{array}$ & & $\checkmark$ & $\checkmark$ & $\checkmark$ & $\checkmark$ \\
\hline Format FEs & & $\checkmark$ & $\checkmark$ & $\checkmark$ & $\checkmark$ \\
\hline $\begin{array}{l}\text { Party Pair } \\
\text { FEs }\end{array}$ & & & $\checkmark$ & $\checkmark$ & $\checkmark$ \\
\hline Observations & 128,881 & 46,059 & 46,059 & 20,322 & 7,367 \\
\hline $\mathrm{R}^{2}$ & 0.028 & 0.067 & 0.358 & 0.534 & 0.419 \\
\hline Adjusted $\mathrm{R}^{2}$ & 0.028 & 0.066 & 0.280 & 0.438 & 0.299 \\
\hline Note: & & & ${ }^{*} \mathrm{p}<0.05$ & ${ }^{* *} p<0.01$ & ${ }^{* * *} p<0.001$ \\
\hline
\end{tabular}


TABLE A.2: GENERAL COUNSEL INFLUENCE ON DisPuTE RESOLUTION CLAUSES

\begin{tabular}{|lc|c|c|c|c|}
\hline & \multicolumn{5}{c|}{ Dependent Variable: } \\
\cline { 2 - 7 } & $(1)$ & $(2)$ & $(3)$ & $(4)$ & $(5)$ \\
\hline Diff $G C$ & 0.014 & -0.005 & $0.058^{* * *}$ & $0.073^{*}$ & -0.096 \\
& $(0.014)$ & $(0.021)$ & $(0.014)$ & $(0.034)$ & $(0.070)$ \\
\hline Diff Year & & $0.018^{* * *}$ & $0.017^{* * *}$ & $0.035^{* * *}$ & $0.038^{* * *}$ \\
& & $(0.003)$ & $(0.002)$ & $(0.003)$ & $(0.009)$ \\
Constant & $0.418^{* * *}$ & $0.318^{* * *}$ & & & \\
& $(0.010)$ & $(0.025)$ & & & \\
Exact & & $\checkmark$ & $\checkmark$ & $\checkmark$ & $\checkmark$ \\
Matching & & & & & \\
Industry FEs & & $\checkmark$ & $\checkmark$ & $\checkmark$ & $\checkmark$ \\
Contract & & $\checkmark$ & $\checkmark$ & $\checkmark$ & $\checkmark$ \\
Type FEs & & & & & \\
\hline Format FEs & & $\checkmark$ & $\checkmark$ & $\checkmark$ & $\checkmark$ \\
Party Pair & & & $\checkmark$ & $\checkmark$ & $\checkmark$ \\
FEs & & & & & \\
\hline Observations & 370,779 & 83,956 & 83,956 & 17,627 & 9,247 \\
\hline$R^{2}$ & 0.0002 & 0.057 & 0.208 & 0.434 & 0.359 \\
\hline Adjusted R ${ }^{2}$ & 0.0002 & 0.057 & 0.182 & 0.368 & 0.281 \\
\hline \hline Note: & & & ${ }^{*} \mathrm{p}<0.05$ & $*{ }^{* *} \mathrm{p}<0.01$ & ${ }^{* * *} \mathrm{p}<0.001$ \\
\hline
\end{tabular}


TABLE A.3: COLLAPSE-INDUCED LAW FIRM CHANGES

\begin{tabular}{|c|c|c|}
\hline & \multicolumn{2}{|c|}{ Dependent Variable: } \\
\hline & \multicolumn{2}{|c|}{ Difference in Dispute Resolution Clause } \\
\hline & No Party FEs & Party FEs \\
\hline Collapsed & $\begin{array}{l}0.251^{*} \\
(0.107)\end{array}$ & $\begin{array}{l}0.331^{*} \\
(0.149)\end{array}$ \\
\hline Diff Year $_{1}$ & $\begin{array}{c}0.005 \\
(0.003)\end{array}$ & $\begin{array}{c}0.004 \\
(0.003)\end{array}$ \\
\hline Collapsed $*$ Diff Year & $\begin{array}{c}0.002 \\
(0.010)\end{array}$ & $\begin{array}{l}-0.015 \\
(0.017)\end{array}$ \\
\hline Constant & $\begin{array}{c}0.107 * * * \\
(0.019)\end{array}$ & \\
\hline Exact Matching & $\checkmark$ & $\checkmark$ \\
\hline Industry FEs & $\checkmark$ & $\checkmark$ \\
\hline Contract Type FEs & $\checkmark$ & $\checkmark$ \\
\hline Format FEs & $\checkmark$ & $\checkmark$ \\
\hline Party Pair FEs & & $\checkmark$ \\
\hline Observations & 16,356 & 16,356 \\
\hline $\mathrm{R}^{2}$ & 0.050 & 0.442 \\
\hline Adjusted $\mathrm{R}^{2}$ & 0.048 & 0.333 \\
\hline Note: & ${ }^{*} \mathrm{p}<0.05$ & ${ }^{* * *} \mathrm{p}<0.01 \quad{ }^{* * * *} \mathrm{p}<0.001$ \\
\hline
\end{tabular}

TABle A.4: Client Retention AfTer COLlapse

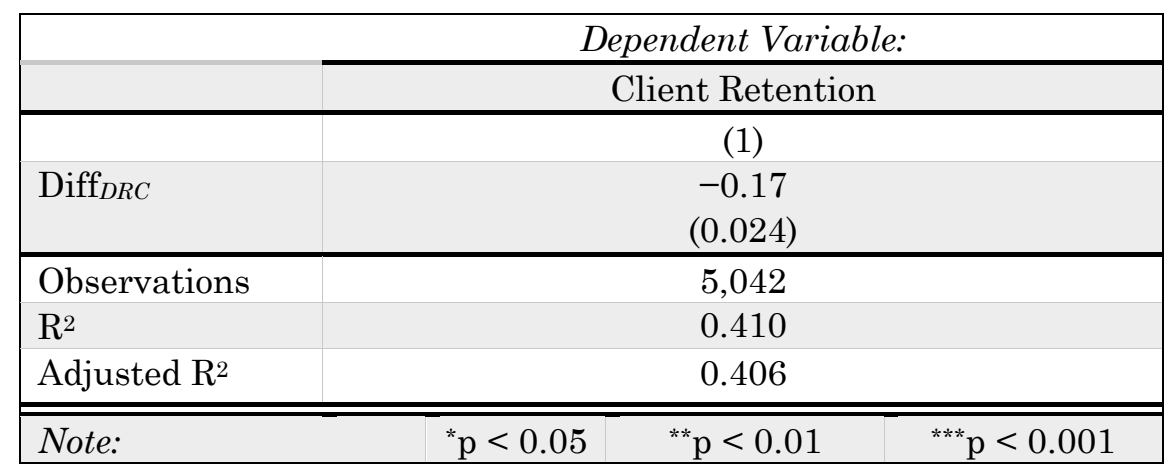


TABLE A.5: INFLUENCE OF THE FIRST DRAFT

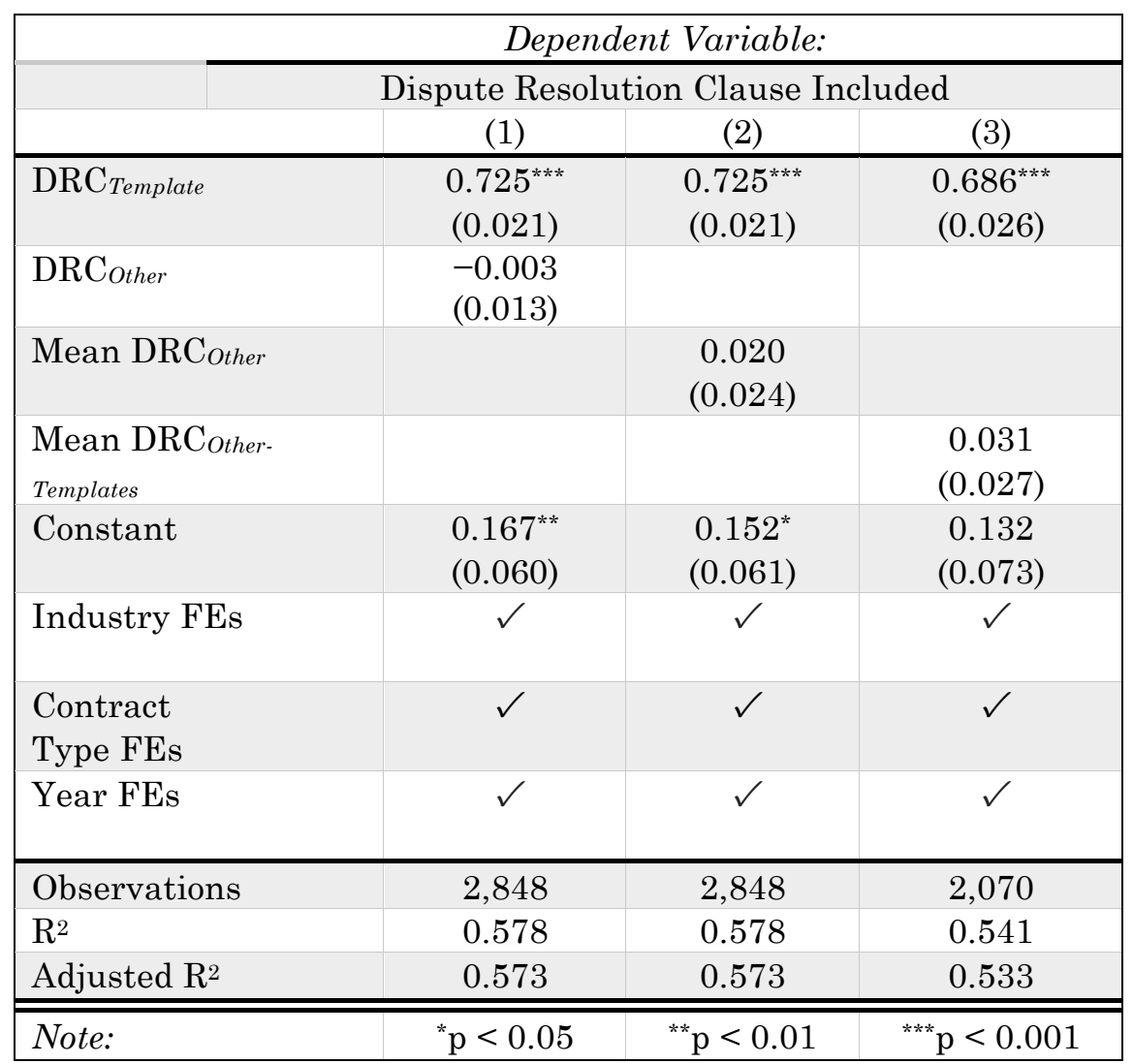

